\title{
ESTIMATIVAS DE PARÂMETROS GENÉTICOS EM POPULAÇÕES DE MILHO BRAQUTICO, PELO DELINEAMENTO I, DE COMSTOCK E ROBINSON
}

\author{
SEBASTIĀO DE OUVEIRA E SILVA \\ Engenheiro Agrónomo
}

Orientador. Prof. Dr. GERALDO ANTONIO TOSELLO

\begin{abstract}
Tese apresentada à Escola Superior de Agit cultura Luiz de Queirot, da Universidade de Săo Paulo, para obtenģo do titulo de Doutor em Agronomia, Area de Consentuasáa Gene tica e Melhoramento de Plantas.
\end{abstract}

PIRACICABA

Estedo de S5o Paulo - Brasil

Agosto-1990 
Ficha catalográfica preparada pela Seção de Livrós da Divisão de Biblioteca e Documentação - PCAP/USF

Silva, Sebastiăo de Oliveira e

S586e Estimativas de parâmetros genéticos em populaçốes de milho braquitico, pelo delineamento $\mathrm{I}$, de Constuck e Robinson. Piracicaba, 1990.

$138 \mathrm{p}$.

Tese - ESALQ

Bibliografia.

1. Milho - Melhoramento 2. Milho - População - Parâmetro genético 3. Milho - População - Teor de óleo 4. Milho - Populaçăo - Variaçăo fenotípica 5. Milho População - Variação genética 6. Milho - Progênie I. Escola Superior de Agricultura Luiz de Queiroz, Piracicaba 


\title{
ESTIMATIVAS DE PARÂMETROS GENETICOS EM POPULAÇÕES DE MILHO BRAQUUTICO, PELO DELINEAMENTO I, DE COMSTOCK E ROBINSON
}

\author{
SEBASTÃO DE OUNEIRA E SILVA
}

Aprovada errc 180990

\section{Comissấo Julgadora:}

Prof. Dr. Geraldo Antonio Tosello

ESALQ/USP

Prof. Dr. Jožo Rubens Zinsly.

ESALQ/USP

Prof. Dr. José Branco de Miranda Filho

ESALQ/USP

Prof. Dr. Cássio Roberto de Melo Godoi

ESALQ/USP

Dr. Mario Augusto Pinto da Cunha

CNPMFIEMBRAPA

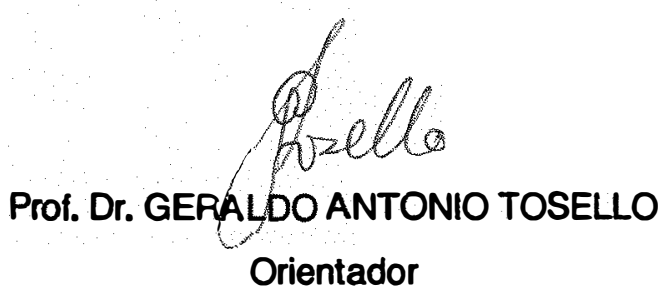


Aos meus pais

(in memoriam)

OFERECOO

À mintra

e filhos,

DEDICO 


\section{AGRADECIMENTOS}

Á Empresa Brasileira de Pesquisa Agropecûaria - EMBRAPA, particularmente ao Centro Nacional de Pesquisa de Mandioca e Fruticultura - CNPMF, pela oportunidade de aperfeiçoamento técnico oferecida, a nivel de pós-graduação;

Ao Conselho Nacional de Desenvolvimento Científico e Tecnológico - CNPq pela concessāo da bolsa de estudos;

Á Financiadora de Estudos e Projetos - FINEP pelo subsidio de todo o projeto de pesquisa;

Ao Prof. Dr. Geraldo Antonio Tosello, pelo interesse científico, orientação e amizade;

Ao Prof. Dr. Claúdio Lopes de Souza Junior pela colahoração prestada na condução deste esturio;

Aos professores do Curso de Genética e Melhoramento de Plantas da ESALQ-USP, pelos ensinamentos ministrados;

Ao colega Cosme Damião Cruz pela ajuda nas análises estatístico-genéticas;

A todos que direto ou indiretamente contrihuiram para o hom éxito deste trahalho;

Meus agradecimentos 


\section{SUMÁRIO}

Página

LISTA DE FIGURAS $\ldots \ldots \ldots \ldots \ldots \ldots \ldots \ldots \ldots \ldots \ldots \ldots$ vii

LISTA DE TABELAS $\ldots \ldots \ldots \ldots \ldots \ldots \ldots \ldots \ldots \ldots \ldots \ldots \ldots \ldots \ldots \ldots$

RESUMO $\ldots \ldots \ldots \ldots \ldots \ldots \ldots \ldots \ldots \ldots \ldots \ldots \ldots \ldots \ldots \ldots \ldots \ldots \ldots \ldots$

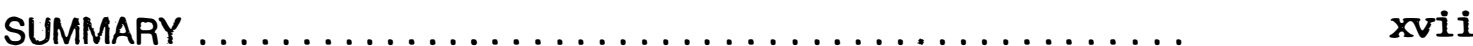

1. INTRODUÇÃO $\ldots \ldots \ldots \ldots \ldots \ldots \ldots \ldots \ldots \ldots \ldots \ldots \ldots \ldots \ldots$

2. REVISÃO DE LITERATURA ................... 3

2.1. Composiçāo quimica do grâo de milho............... 3

2.2. Ácidos graxos do óleo do grâo de milho................ 4

2.3. Fatores que afetam a percentagem do óleo em milho.......... 8

2.3.1. Efeito ambiental ....................... 8

2.3.2. Efeito da fonte polinizadora ................. 8

2.3.3. Efeito da posiçáo da espiga na planta e dos grãos na espiga.

2.3.4. Efeito matemo. . . . . . . . . . . . . . . . . . . . . 10

24. Genes envolvidos com o conteúdo de óleo em milho. . . . . . . . . . 12

2.4.1. Genes envolvidos com os ácidos graxos............. 14

2.4.2. Localização de genes que controlam o teor de ácidos graxos. 15

2.4.3. Efeito da endogamia sobre o teor de óleo . . . . . . . . . . 15

25. Alteraçōes morfo-fisiológicas do grão resultantes da seleção para óleo ................................. 16

26. Variabilidade genética do conteúdo de óleo em milho.......... 18

2.7. Variabilidade genética em caracteres da planta do milho......... 19 
2.8. Relação entre teor de b́leo do gráo de milho com outras características da planta.............................. 22

2.9. Métodos de seleção usados para aumentar o teor de óleo em milho.

3. MATERIAL E MÉTODOS $\ldots \ldots \ldots \ldots \ldots \ldots \ldots \ldots \ldots \ldots \ldots \ldots$

3.1. Material .............................. 29

3.2. Métodos .............................. 30

3.2.1. Obtenção das progênies do delineamento I de Comstock e Robinson............................. 30

3.2.2. Execuçâo experimental .................... 30

3.2.2.1. Campo ...................... 30

3.2.2.2. Análise de laboratório .................. 33

3.2.3. Análise estatístico-genética ................. 33

3.2.4. Análises de variancia........................ 34

3.2.5. Análises de covariância..................... 38

3.2.6. Distribuiçâo de frequências das médias dos caracteres...... 41

3.2.7. Precisão das estimativas .................... 42

4. RESULTADOS E DISCUSSĀO ....................... 43

4.1. Médias populacionais $\ldots \ldots \ldots \ldots \ldots \ldots \ldots \ldots \ldots \ldots \ldots$

4.1.1. Médias populacionais para caracteres da planta......... 45

4.1.2. Médias populacionais para teor de óleo............. 46

4.2. Consideraçōes sobre o delineamento $1 \ldots \ldots \ldots \ldots \ldots \ldots \ldots .47$

4.3. Potencial das populaçōes para o melhoramento ............ 48 
Página

4.3.1. Coeficientes de variação experimental (CVe\%), genética ( $C V g \%)$ e indice de variação ( $b=C V g \% / C V e \%)$ para caracteres da planta. . . . . . . . . . . . . . . . . . . .

4.3.2. Coeficientes de variação experimental (CVe\%), genética (CVg\%) e indice de variação ( $b=C V g \% / C V e \%)$ para teor de óleo

4.3.3. Variâncias genéticas ambientais e fenotípicas para caracteres da planta. . . . . . . . . . . . . . . . .

4.3.4. Variâncias genéticas ambientais e fenotípicas para teor de

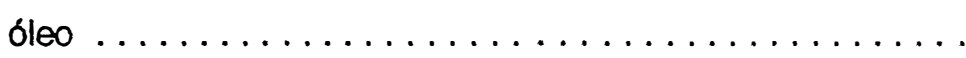

4.3.5. Coeficientes de herdahilidade para caracteres da planta. . . . .

4.3.6. Coeficientes de herdabilidade para teor de óleo. . . . . . . . .

4.3.7. Progressos esperados com a seleção para caracteres da plan-

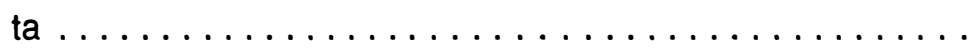

4.3.8. Progressos esperados com a seleção para teor óleo de milho.

4.4. Associação entre caracteres. . . . . . . . . . . . . . .

4.4.1. Correlaçōes genéticas e fenotípicas entre rendimento de espiga e outros caracteres da planta. . . . . . . . . . . .

4.4.2. Correlaçōes genéticas e fenotípicas entre o teor de óleo e outros caracteres da planta . . . . . . . . . . . . . . . . . . .

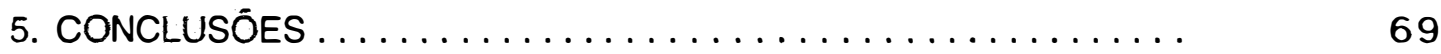

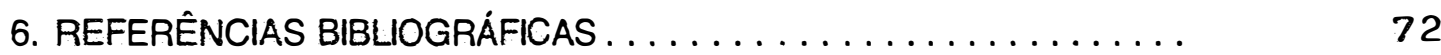

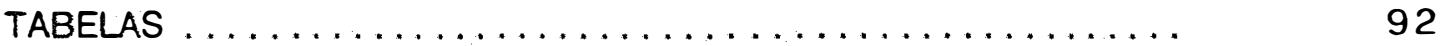

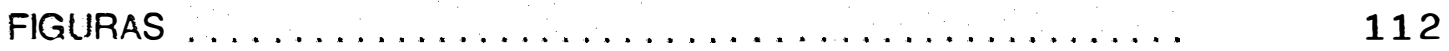

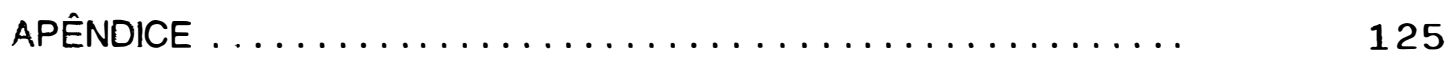




\section{USTA DE FGURAS}

Página

FIGURA 1 - Distribuição das médias para teor de óleo (\%), referente as populações Piranão VD-2 e Piranão VF-1, destacando-se o número de médias ( $N$ ), a amplitude de variação (AV) e a média geral (X) com o respectivo intervalo de confiança (IC) a $5 \%$ de probabilidade. Piracicaba-SP. (Caterpillar). 1985/86. . . . . . . . . .

FIGURA 2 - Distribuição das médias para rendimento de espiga $\left(\mathrm{kg} / 5 \mathrm{~m}^{2}\right)$, referente as populaçōes Piranāo VD-2 e Piranāo VF-1, destacando-se o número de médias $(\mathrm{N})$, a amplitude de variação (AV) e a média geral $(\bar{X})$ com o respectivo intervalo de confiança (IC) a $5 \%$ de probabilidade. Piracicaba-SP. (Caterpillar).

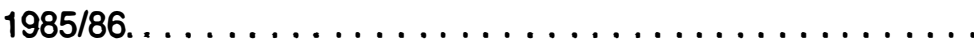

FIGURA 3 - Distribuição das médias para peso de espiga (g), referente as populaçōes Piranão VD-2 e Piranão VF-1, destacando-se 0 número de médias $(N)$, a amplitude de variação (AV) e a média geral (X) com o respectivo intervalo de confiança (IC) a $5 \%$ de probabilidade. Piracicaba-SP. (Caterpillar). 1985/86. . . . . . . .

FIGURA 4 - Distribuição das médias para peso de grãos (g), referente as populaçōes Piranão VD-2 e Piranão VF-1, destacando-se o número de médias (N), a amplitude de variação (AV) e a média geral $(X)$ com o respectivo intervalo de confiança (IC) a $5 \%$ de probabilidade. Piracicaba-SP. (Caterpillar). 1985/86. . . . . . . . 
FIGURA 5 - Distribuiçāo das médias para peso de 100 grãos $(\mathrm{g})$, referente as populaçōes Piranão VD-2 e Piranão VF-1, destacando-se 0 número de médias $(\mathrm{N})$, a amplitude de variaçāo $(\mathrm{AV})$ e a média geral $(\bar{X})$ com o respectivo intervalo de confiança (IC) a $5 \%$ de probabilidade. Piracicaba-SP. (Caterpillar). 1985/86. . . . . . . .

FIGURA 6 - Distribuiçāo das médias para número de fileiras de grãos ( $n$ o fileira/espiga), referentes as populaçōes Piranāo VD-2 e Piranāo VF-1, destacando-se o número de médias (N), a amplitude de variação (AV) e a média geral $(\bar{X})$ com o respectivo intervalo de confiança (IC) a $5 \%$ de probabilidade. PiracicabaSP. (Caterpillar). 1985/86. . . . . . . . . . . . . . . .

FIGURA 7 - Distribuiçāo das médias para número de grāos por fileira ( $n$ 은 grāos/fileira), referentes as populaçōes Piranāo VD-2 e Piranāo VF-1, destacando-se o número de médias $(\mathrm{N})$, a amplitude de variação $(A V)$ e a média geral $(\bar{X})$ com o respectivo intervalo de confiança (IC) a $5 \%$ de probabilidade. PiracicabaSP. (Caterpillar). 1985/86. . . . . . . . . . . . . . . . . .

FIGURA 8 -Distribuição das médias para diâmetro de espiga $(\mathrm{cm})$, referentes as populaçōes Piranāo VD-2 e Piranāo VF-1, destacando-se o número de médias ( $N$ ), a amplitude de variaçāo $(A V)$ e a média geral $(X)$ com o respectivo intervalo de confiança (IC) a 5\% de probabilidade. Piracicaba-SP. (Caterpillar).

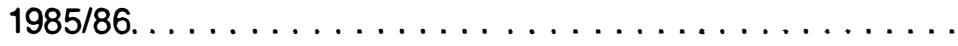


FIGURA 9 -Distribuição das médias para comprimento de espiga $(\mathrm{cm})$, referentes as populaçōes Piranão VD-2 e Piranão VF-1, destacando-se o número de médias $(N)$, a amplitude de variação (AV) e a média geral $(\bar{X})$ com o respectivo intervalo de confiança (IC) a 5\% de prohabilidade. Piracicaba-SP. (Caterpillar). 1985/86. . . . . . . . . . . . . . . . . . . . . . . . . . .

FIGURA 10 - Distribuição das médias para diâmetro de sabugo $(\mathrm{cm})$, referentes as populaçōes Piranão VD-2 e Piranão VF-1, destacando-se o número de médias $(N)$, a amplitude de variação (AV) e a média geral $(\bar{X})$ com o respectivo intervalo de confiança (IC) a 5\% de probabilidade. Piracicaba-SP. (Caterpillar).

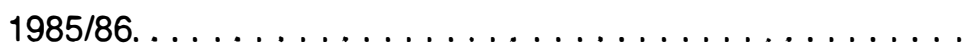

FIGURA 11 - Distrihuição das médias de altura de planta $(\mathrm{cm})$, referentes as populaçōes Piranão VD-2 e Piranão VF-1, destacando-se 0 número de médias ( $N$ ), a amplitude de variação (AV) e a média geral $(\bar{X})$ com o respectivo intervalo de confiança (IC) a 5\% de probabilidade. Piracicaba-SP. (Caterpillar). 1985/86. . .

FIGURA 12 - Distribuição das médias de altura de espiga (cm), referentes as populaçōes Piranão VD-2 e Piranão VF-1, destacando-se 0 número de médias (N), a amplitude de variação (AV) e a média geral $(\bar{X})$ com o respectivo intervalo de confiança (IC) a 5\% de probabilidade. Piracicaba-SP. (Caterpillar). 1985/86. . . 


\section{LISTA DE TABELAS}

Página

TABELA 1 - Esperanças matemáticas dos quadrados médios das análises de variâncias segundo o delineamento I, ao nivel de média de

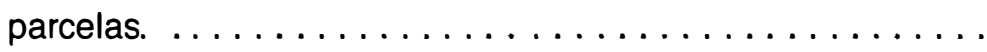

TABELA 2 - Esperanças matemáticas para os produtos médios das análises de covariâncias segundo o delineamento I, ao nivel de médias de parcelas . . . . . . . . . . . . . . .

TABELA 3 - Valores médios obtidos para os caracteres teor de óleo (TO), rendimento de espiga (RE), peso de espigas (PE), peso de grãos (PG), peso de 100 grãos (P100), número de fileiras de grãos por espiga (NF), número de grãos por fileira (GF), diâmetro de espiga (DE), comprimento de espiga (CE), diâmetro de sabugo (DS), altura de planta (AP), altura de espiga (AE) e os respectivos intervalos de confiança (IC) a $5 \%$ de probabilidade, referentes às populaçōes Piranão VD-2 e Piranão VF-1, Piracicaba, SP (Caterpillar). 1985/86. . . . . . . . . . . . . .

TABELA 4 - Valores de significância dos quadrados médios obtidos a niveis de médias de parcelas de 12 caracteres da planta da populaçāo Piranāo VD-2. Piracicaba, SP. (Caterpillar). 1985/86. . . . . .

TABELA 5 - Valores de significância dos quadrados médios obtidos a nivel de médias de parcelas de 12 caracteres da planta da populaçāo Piranão VF-1. Piracicaba, SP. (Caterpillar). 1985/86 . . . . 
TABELA 6 - Estimativas para variância de machos $\left(\hat{\sigma}_{\mathrm{m}}^{2}\right)$, variância de fế meas dentro de machos ( $\left.\hat{\sigma}_{\mathrm{f} / \mathrm{m}}^{2}\right)$, variância genética aditiva $\left(\begin{array}{cc}\hat{\sigma} & 2\end{array}\right)$, variância genética dominante ( $\hat{\sigma} \frac{2}{D}$ ), variância ambiental entre parcelas ( $\hat{\boldsymbol{\sigma}} 2$, variância fenotípica dentro de progê-

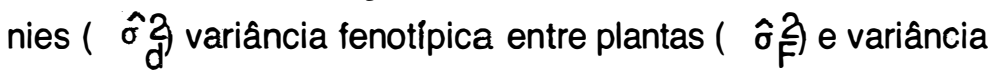
entre médias de famílias de meios irmãos ( $\hat{\sigma} \frac{2}{F}$ ) razão entre variância de dominância, variância aditiva $\left(\begin{array}{ccc}\hat{\sigma}_{0}^{2} & \hat{\sigma}_{\hat{A}}^{2}\end{array}\right)$ e os respectivos coeficientes de herdabilidade no sentido restrito a nivel de plantas individuais $\left(h^{2}\right)$ e ao nivel de médias de família de meios irmãos ( $\frac{h 3}{x}$ para 12 caracteres da planta da população Piranão VD-2. Piracicaba-SP. (Caterpillar), 1985/86. . . . . .

TABELA 7 - Estimativas para variância de machos ( $\hat{\sigma} \underset{\mathrm{m}}{2}$ ), variância de fêmeas dentro de machos ( $\hat{\sigma}_{\mathrm{f} / \mathrm{m}}^{2}$ ), variância genética aditiva ( $\left.\begin{array}{cc}\hat{\sigma} & 2\end{array}\right)$, variância genética dominante ( $\left.\begin{array}{ll}\hat{\sigma} & 2 \\ D\end{array}\right)$, variância ambiental entre parcelas ( $\hat{\sigma} 2)$, variância fenotípica dentro de progênies ( $\hat{\sigma} \hat{d}$ ) variância fenotípica entre plantas ( $\hat{\sigma} \hat{F}$ ) e variância fenotípica entre médias de famílias de meios irmãos ( $\hat{\sigma} 3$ ) razāo entre variância de dominância, variância aditiva $\left(\begin{array}{lll}\hat{\sigma} & 2 / \hat{\sigma}^{2} & 2\end{array}\right)$ e os respectivos coeficientes de herdabilidade no sentido restrito a nivel de plantas individuais $\left(h^{2}\right)$ e ao nivel de médias de família de meios irmãos ( $h \stackrel{\not}{X}$ para 12 caracteres da planta da população Piranão VF-1. Piracicaba-SP. (Caterpil(ar), $1985 / 86 \ldots \ldots \ldots \ldots \ldots \ldots \ldots \ldots \ldots$

TABELA 8 - Estimativas dos progressos esperados (Gs 1 ) por ciclo, para 11 caracteres da planta das populaçōes Piranão VD-2 e Piranão VF-1, com seleção massal em um só sexo, considerandose a intensidade de seleção a 10\%. Piracicaba, SP. (Caterpillar), $1985 / 86 \ldots \ldots \ldots \ldots \ldots \ldots \ldots \ldots$ 
TABELA 9 - Estimativas dos progressos esperados (Gs2) por ciclo, para 12 caracteres da planta das populaçoes Piranão VD-2 e Piranão VF-1, com seleção entre familias de meios irmãos, com sementes remanescentes, considerando-se a intensidade de seleção de 20\%. Piracicaba, SP. (Caterpillar), 1985/86. . . . .

TABELA 10 - Produtos médios ao nivel de médias de parcela, relativos às combinaçōes entre teor de óleo e 11 caracteres da planta da população Piranão VD-2. Piracicaba,SP. (Caterpillar),

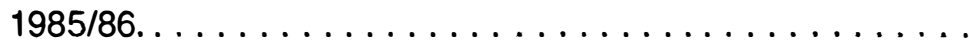

TABELA 11 - Produtos médios ao nivel de médias de parcela, relativos às combinaçōes entre teor de óleo e 11 caracteres da planta da população Piranão VF-1. Piracicaba,SP. (Caterpillar), 1985/86.

TABELA 12 - Produtos médios ao nivel de médias de parcela relativos às combinaçōes entre rendimento de espiga e dez caracteres da planta da população Piranão VD-2. Piracicaba-SP. (Caterpil-

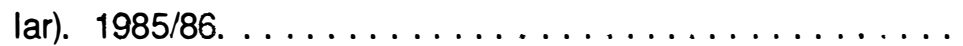

TABELA 13 - Produtos médios ao nivel de médias de parcela, relativos às combinaçōes entre rendimento de espiga e dez caracteres da planta da populaçāo Piranão VF-1. Piracicaba, SP. (Caterpil-

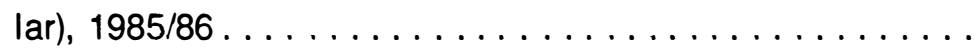

TABELA 14 - Estimativas obtidas para covariância de macho $\left(C O \hat{O} V_{m}\right), \infty$ variância de fêmeas dentro de machos $\left(C O \hat{} V_{f / m}\right)$, covariância genética aditiva $\left(\mathrm{CÔV}_{\mathrm{A}}\right)$, covariância genética dominante (CÔV $V_{D}$, covariância ambiental (CÔV $V_{e}$ e civariância de média de familias de meios irmãos $\left(C O V_{F}\right)$ entre teor de óleo e 11 caracteres da planta da população VD-2. Piracicaba, SP. (Caterpillar). 1985/86. . . . . . . . . . . . . . . . . . . . 
Página

TABELA 15 - Estimativas obtidas para covariância de macho $\left(C O ̂ V_{m}\right)$, covariância de fêmeas dentro de machos $\left(\mathrm{C}_{\text {Ô }} \mathrm{V}_{\mathrm{f} / \mathrm{m}}\right)$, covariância

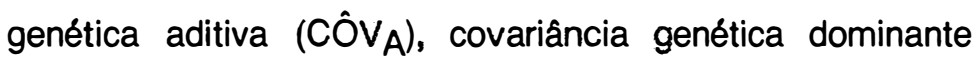
$\left(C O V_{D}\right)$, covariância ambiental (CÔVe $)$ e covariância de média de familias de meios irmãos (CÔVF) entre teor de óleo e 11 caracteres da planta da populaçāo VF-1. Piracicaba, SP. (Caterpillar). 1985/86. . . . . . . . . . . . . . .

TABELA 16 - Estimativas obtidas para covariância de macho $\left(C \hat{O} \mathrm{~V}_{m}\right)$, covariância de fêmeas dentro de machos $\left(C O \hat{⿰} \mathrm{~V}_{\mathrm{f} / \mathrm{m}}\right)$, covariância genética aditiva $\left(C \hat{O} \mathrm{~V}_{\mathrm{A}}\right)$, covariância genética dominante (CÔV $)$, covariância ambiental (Cố $\mathrm{e}$ ) e covariância de média de famílias de meios irmãos (CÔV $F$ ) entre rendimento de espiga e dez caracteres da planta da população VD-2. Piracicaba, SP. (Caterpillar). 1985/86. . . . . . . . . . . . . .

TABELA $17^{\circ}$ - Estimativas obtidas para covariância de macho $\left(\mathrm{CÔV}_{\mathrm{m}}\right)$, covariância de fêmeas dentro de machos $(C O \hat{\mathrm{f}} / \mathrm{m})$, covariância genética aditiva $\left(C O ̂ V_{A}\right)$, covariância genética dominante (CÔV $D)$, covariância ambiental (CÔVe $)$ e covariância de média de familias de meios irmãos (CÔ $\left.V_{F}\right)$ entre rendimento de espiga e dez caracteres da planta da populaçāo VF-1. Piracicaba, SP. (Caterpillar). 1985/86. . . . . . . . . . . . . . .

TABELA 18 - Estimativas de coeficientes de correlaçāo entre rendimento de espiga e dez caracteres da planta das populaçōes Piranão VD-2 e Piranāo VF-1. Piracicaba, SP (Caterpillar), 1985/86 . . 
TABELA 19 - Estimativas de coeficientes de correlação entre teor de óleo e 11 caracteres da planta das populações Piranão VD-2 e Piranão VF-1. Piracicaba, SP (Caterpillar), 1985/86. . . . . . . . .

TABELA 20 - Estimativas das respostas correlacionadas $(R y / x)$ por ciclo, no teor de óleo, quando uma seleção entre (20\%) progenies de meios irmãos foi feita em 11 caracteres, da planta das populaçōes Piranão VD-2 e Piranão VF-1. Piracicaba, SP (Caterpillar), $1985 / 86 \ldots \ldots \ldots \ldots \ldots \ldots \ldots \ldots \ldots$

TABELA 21 - Estimativas das respostas correlacionadas (Ry/x) por ciclo em 11 características, quando uma seleção entre (20\%) progenies de meios irmãos foi feita no teor de óleo das plantas da populaçāo Piranão VD-2 e Piranāo VF-1. Piracicaba, SP (Caterpillar), $1985 / 86 \ldots \ldots \ldots \ldots \ldots \ldots \ldots \ldots \ldots$ 


\section{ESTIMATIVAS DE PARÂMETROS GENÉTICOS EM POPULAÇŌES DE MUHO BRAQUITICO, PELO DELWNEAMENTO I, DE COMSTOCK E ROBINSON}

Autor: SEBASTIÃO DE OLIVEIRA E SILVA

Orientador: Dr. GERALDO ANTONIO TOSELLO

\section{RESUMO}

Com o objetivo de avaliar o comportamento genético e fenotípico de duas populaçōes de milho braquítico, foram obtidas, pelo delineamento I de Comstock e Robinson, 364 e 381 progênies respectivamente das populaçóes Piranão VD-2 e Piranão VF-1. Foram avaliados os caracteres teor de óleo (TO), rendimento de espiga (RE), peso de espiga (PE), peso de grãos (PG), peso de 100 grãos (P100), número de fileiras de grãos por espiga (NF), número de grăos por fileira (GF), diâmetro de espiga (DE), comprimento de espiga (CE), diâmetro de sabugo (DS), altura da planta (AP) e altura da espiga (AE). Os dados foram obtidos de ensaios conduzidos em Piracicaba no periodo de 1985/86. Usou-se o delineamento experimental de látice, com uma parcela de $5 \mathrm{~m}^{2}$ (25 plantas), empregando-se como testemunhas os híbridos duplos Ag 352 B e DEK XL 540. O RE foi avaliado em toda parcela e os demais caracteres em amostras ( $\leq 5$ plantas) dentro da parcela.

Além das estimativas de médias, foram estimados, com as análises de variância e covariância, os seguintes parâmetros: variâncias fenotípicas e genéticas, coeficientes de herdabilidade, no sentido restrito, ao nivel de plantas e de médias de progénies; coeficiente de variação experimental $(\mathrm{CVe})$ e genético $(\mathrm{CVg})$; indice de variação $(\mathrm{b}=\mathrm{CVg} / \mathrm{CVe})$; coeficientes de correlação fenotipicos e genéticos entre caracteres; progressos e respostas correlacionadas esperados com a seleção. 
As duas populaçbes apresentaram médias idénticas de RE, AP, AE e TO médios superiores, aqueles observados nas testemunhas. Todos caracteres avaliados (com exceção do PE, GF, NF, DE, DS, AP da população Piranão VD-2) nestas populaçbes apresentaram variância genética aditiva suficiente para permitir o melhoramento, no entanto, somente os caracteres TO, NF, CE, DS das duas populaçбees e DE, AP e AE da população Piranão VD-2 e RE da população Piranão VF-1 apresentaram variância de dominância diferente de zero.

As estimativas de herdabilidade e dos progressos esperados com a seleção massal e seleção de famillias de meios irmãos dos caracteres RE, PE, PG, P100, NF, GF, $D E, D S, A P$ e AE da população Piranão VF-1 foram superiores aquelas da Piranão VD-2. $O$ contrário ocorreu para $h^{2}$ e $G_{S}$ dos caracteres TO e CE, em que as maiores estimativas foram observadas na população Piranão VD-2.

O RE foi positivamente correlacionado com todos os outros caracteres nas duas populaçōes. A população Piranão VD-2 apresentou as maiores correlações entre RE e os caracteres PE, PG, NF, DS e AE e menores entre RE e os caracteres P100, GF, DE, CE e AP do que aquelas observadas na população Piranão VF-1. Todos os caracteres da população Piranão VD-2 foram positivamente correlacionados com o TO. As correlações entre o TO e os caracteres RE, PE, PG, P100, GF, DE, AP e AE da população VF-1 foram também positivas embora de menor magnitude. Foi observada uma baixa correlação negativa entre TO e os caracteres NF, CE e DS da Piranão VF-1.

As respostas correlacionadas nos caracteres PE, PG, CE, DS e AP, com a seleção no teor de óleo foram maiores que os ganhos na seleção direta destes caracteres da população Piranão VD-2. Na população Piranão VF-1 nenhum caráter apresentou ganho indireto, com a seleção para TO superior ao ganho com seleção direta. 


\title{
ESTIMATES OF GENETIC PARAMETERS IN MALE BRACHYTIC POPULATIONS USING THE DESIGN I OF COMSTOCK AND ROBINSON
}

\author{
Author: SEBASTIÃO DE OLIVEIRA E SILVA \\ Adviser: Prof. GERALDO ANTONIO TOSELLO
}

\section{SUMMARY}

The research was carried out in order to evaluate the genetic and phenotypic performance of two brachytic maize populations by using the Design I suggested by Commstock and Robinson.

Were analysed 364 and 381 progenies from each population Piranão VD-2 and Piranåo VF-1. Data were obtained for oil content (TO), ear yielding (RE), ear weight (PE), kemel weight (PG), 100 kernel weight (P100), kemel row number (NF), kernel number per row (GF), ear diameter (DE), ear length (CE), cob diameter (DS), plant height (AP) and ear height (AE). The experimental evaluation was done in Piracicaba in 1985/86 using a square lattice design having each plot $5,0 \mathrm{~m}^{2}$ (25 plants) using as testers the double cross Ag 352-B and DEK XL 540. The RE data was evaluated using the whole plot and among the others only 5 plants were considered from each plot.

From the analysis of variance and covariance the following estimates were obtained: phenotypic and genetic variances, coefficients of heritability, coefficient of experimental variation $\left(C V_{e}\right)$ and genetic variation $\left(C V_{g}\right)$, variation index $\left(b=C V_{g} / C V_{e}\right)$, coefficient of phenotypic and genetic correlation, expected genetic gain and expected genetic correlated response with selection.

Both population presented the same average performance for $R E, A P, A E$ and were greater in TO compared to the testers. Among the characters evaluated for both populations, enough genetic variance was detected to permit breeding exception done for PE, 
$P G, N F, D E, D S$ and $A P$ within the Piranão VD-2. On the other hand it was identified that TO, $N F, C E, D S$ in both populations and DE, AP and $A E$ in the Piranão VD-2 and RE in the Piranão VF-1 presented a dominant genetic variance different from zero.

The estimates of heritability and genetic progress considering mass selection and selection using half-sib families on the characters RE, PE, PG, P100, NF, GF, DE, AP and AE within the Piranão VF-1 were higher compared to the Piranão VD-2. Values in the opposite direction were obtained for $h^{2}$ and $\Delta_{G}$ when TO and CE were considered within the Piranão VD-2 population. The RE showed a positive genetic correlation with all the characters under analysis in both populations. The Piranão VD-2 population showed higher correlation values between RE and PE, PG, NF, DS and $A E$, and the lower values between RE and P100, GF, DE, CE, AP than Piranão VF-1.

All the comparisons done against TO were positively correlated for population VD-2. Within the population VF-1 lower positive values for correlation were identified involving TO and RE, PE, PG, P100, GF, DE, AP and AE. Some lower negative correlation values also were detected mainly for TO against NF, CE and DS in the VF-1 population.

The correlated genetic response for $P E, P G, C E, D S$ and $A P$ against TO showed to be higher than the gain with direct selection in the Piranão VD-2. In the Piranão VF-1 the gain was higher when the direct selection procedure was considered. 


\section{1 - INTRODUÇĀO}

O uso do óleo de milho diretamente na alimentação humana tem aumentado significativamente nos últimos anos, graças as suas qualidades dietéticas. Isto se deve à elevada proporção de ácidos graxos insaturados em relação aos saturados evitando assim, elevação dos niveis de colesterol no sangue e minimizando os problemas cardiovasculares e de hipertensão (FITCH, 1985). Apesar disto, são raros os programas de melhoramento visando modificar o teor de óleo em grãos de milho.

As linhagens e hibridos de milho apresentam teores de óleo que variam de 2,5 a $5,5 \%$ e 4 a $5 \%$ respectivamente.

Milho com alto teor de óleo constitui-se em um atrativo para uso em raçōes, devido a demanda de alta caloria na ālimentạ̧āo de aves, suinos e bovinos. Além da elevada conversão alimentar, estas raçōes fornecem maiores proporçōes de carotenóides, que melhora a pigmentação da pele e do plasma das aves. O bleo do milho é usado na indústria 
alimentícia em produtos de padaria, óleo de cozinha, margarina, maionese, tempero de saladas, sendo também empregado na fabricaçăo de munição, cosméticos, esmaltes, sabăo e óleo so lủvel.

O teor de óleo é um caráter quantitativo controlado principalmente por genes de açăo aditiva (EL ROUBY \& PENNY, 1967; MORENO-GONZALES et alii 1975; DUDLEY et alii, 1977; MILLER et alii, 1981). Os resultados obtidos por MORENOSGONZALES et alii (1975), que consideram a açăo gênica dominante importante para este caráter divergem daqueles observados por EL ROUBY \& PENNY (1967) e MILLER et alii (1981) que consideram sem importância esse tipo de ação. A maioria dos trabalhos que envolvem estimativas de parâmetros genéticos não estimam a variância de dominância. No entanto, ela pode ser estimada através de sistemas de cruzamentos mais complexos, como os delineamentos I, II e III de Comstock e Robinson.

O melhoramento genético visando aumentar o teor de óleo em milho, é obtido com relativa facilidade, devido a alta herdabilidade deste caráter. $O$ processo de seleção para elevar o teor de bleo no entanto, poderá provocar modificaçōes em outros caracteres da planta, devido as possiveis ligaçóes génicas e ou pleiotropia.

O presente trabalho tem por objetivo estimar os componentes da variância genética e fenotípica de diversos caracteres da planta e da covariância entre o teor de óleo e estes caracteres nas populaçōes Piranão VD-2 e Piranão VF-1, através do delineamento I de Comstock e Robinson. Com estas estimativas calcular os progressos esperados e as respostas correlacionadas, obtendo-se assim informaçōes sobre o potencial genético destas populaçóes para melhoramento intra-populacional e sobre as possiveis alteraçōes nos caracteres da planta provocadas pelo melhoramento para teor de b́leo. 


\section{REVISĀO DE LITERATURA}

\section{Composiçáo quimica do gråo de milto}

O grăo de milho é um fruto de uma só semente, ou cariopse, caracteristico das gramineas. A camada extema (pericarpo), derivada da parede do ovário, com $2 n$ cromossomos, tem constituição genética maternal e pode ser incolor, vermelha, marrom alaranjada ou variegada. A ponta do grăo é a parte remanescente do tecido que conecta o grão ao sabugo e permite uma rápida absorção de umidade. Dentro do grão está o endosperma com 3n cromossomos, sendo que $2 n$ provém da mãe e $n$ da fonte polinizadora, e o embrião com $2 n$ cromossomos. O endosperma, que pode ser branco, amarelo ou laranja, é envolvido por uma camada ou raramente várias camadas de celulas denominadas aleurona, que tem constituiçăo genética $3 n$ e apresenta-se nas cores vermelha, pürpura, azul, bronzeada, marrom, laranja, incolor e amarela (CURTIS et afi, 1956).

O endosperma é responsável por aproximadamente $85 \%$ do peso total do grão, enquanto o embriåo e o pericarpo correspondem respectivamente a 10 e $5 \%$ daquele va- 
lor (KIESSELBACH, 1949). Na Tabela 1 - Apéndice é apresentada uma análise química aproximada do grăo de milho.

A composiçáo química do gråo de milho varia com a linhagem, híbrido ou populaçăo, sendo influenciada pelo tipo de solo, fertilizaçăo e condiçర̃es climáticas. As porcentagens médias de amido, proteina, lipídeos, açúcares e cinzas dos diversos componentes de um milho normal, em base de peso seco, podem ser observadas na Tabela 2 - Apêndice.

O amido do milho comum apresenta $73-78 \%$ de amilopectina (molécula ramificada) e 22-27\% de amilose (molécula não ramificada). As duas moléculas são polímeros de glucose e possuem alto peso molecular. A molécula de amilose contém em média 1.000 unidades de glucose enquanto a da amilopectina pode conter até 40.000 unidades deste açúcar (INGLET, 1970).

As proteinas do grăo são classificadas em albuminas (solúveis em água), globulinas (solưveis em solução de cloreto de sódio), prolaminas (solúveis em etanol a $80 \%$ ) e glutelinas (solúveis em hidróxido de sódio).

Os lipideos ou óleo de milho, compreendem um grupo de subståncias químicas solúveis em solventes de baixa polaridade, como éter de petróleo, $n$-hexano, benzeno, clorofórmio, e praticamente insolúveis em água. Os principais ácidos graxos que os constituem são: ácidos palmítico, esteárico, oleico, linoleico, linolênico e araquídico (BEADLE et alii, 1965; NILSSON et alii, 1968).

\section{2 Ácidos graxos do óleo do gráo de milho}

As variedades e híbridos de milho do Brasil apresentam em média 4,5\% de óleo no grăo, embora haja informaçőes na literatura de variedades comerciais que possuem até $8,7 \%$ de óleo (MAZZARI \& SIQUEIRA, 1982).

Determinando-se os teores de óleo, proteina e carboidratos dos grăos e multiplicando-os pelos respectivos valores de 9,4,5,4 e 4,2 cal/g e somando os produtos tem-se 
o valor calórico do grão (WESTON \& TODD, 1963). Foi observado que este valor em cal/g de matéria seca no grăo está correlacionado, positivamente, com o teor de óleo e em menor grau com percentagem de proteina e negativamente com o rendimento em grăos (DUDLEY et alii, 1977). Apesar da correlaçăo negativa entre a energia de carboidratos e de bleo observada por ALEXANDER \& LAMBERT (1968), eles concluiram que a habilidade de uma planta em produzir carboidratos e sintetizar óleo sáo fisiológicamente independente e que alguns genótipos estão limitados em sua capacidade de estocar energia pelo ineficiente sistema de síntese de óleo.

Através da análise de vários constituintes do grão de milho, foi determinado que cerca de $85 \%$ do total de óleo está contido no embrião (LENG, 1967; CURTIS et alii, 1968; HOPKINS et alii, 1974; VÖRÖSBARANYI, 1981 ), embora no inicio do desenvolvimento da semente o endosperma apresente teores de óleo superiores ao do embriāo (CURTIS, et alii, 1968). Além da diferença em quantidade, o óleo do endosperma apresenta maiores teores de ácidos palmítico, esteárico e linolênico e menores teores de ácido linoleico (JELLUM et alii, 1969).

Os principais ácidos graxos encontrados na semente de milho são: ácidos linoleico $(58 \%)$, oleico (27\%), palmítico (12\%), esteárico (2\%), linolênico $(0,8 \%)$ e araquídico $(0,2 \%)$ (BEADLE et alii, 1965; NILSSON et alii, 1968 e VÖRÖSBARANYI, 1981), ocorrem também o B-caroteno (NILSSON et alii, 1968) e o ácido miristico (VÖRÖSBARANYI, 1981). Os ácidos palmítico e esteárico săo saturados, enquanto o oleico, linoleico e linolênico são insaturados (ROCHE et alii, 1971b e PAMIN et alii, 1986). O grau de insaturação é determinado pelo indice de iodo, que é negativamente correlacionado com a percentagem de oleo (QUACKENBUSH, 1961).

Acentuadas variaçסes nos teores de ácidos graxos podem ocorrer naturalmente ou podem ser obtidas por processos de seleçăo (VÖRÖSBARANYI, 1981; WDSTROM \& JELLUM, 1984). Assim é que JELLUM \& MDSTROM (1983) obtiveram a linhagem 57 a partir de genótipos de milho introduzidos do Nepal que apresentavam de 2,8 a 11,5\% de ácido esteárico. Deste mesmo germoplasma foi obtida a linhagem GE 180 que possue $18,3,13,8$ e $38,2 \%$ respectivamente dos ácidos esteárico, palmítico e linoleico, enquanto os teores médios destes ácidos săo de 2, 12 e 58\% respectivamente. 
A biossintese dos ácidos graxos segue as seguintes etapas: ácido laurico - ácido mirístico - ácido palmítico - ácido esteárico - ácido oleico - ácido linoleico (ALEXANDER \& CREECH, 1977). Uma vez que o ácido oleico é desnaturado para linoleico, explica-se assim as relaçőes observadas entre estes dois ácidos (CURTIS et alii, 1968; PONELEIT \& BAUMAN, 1970 e ROCHE et alii, 1971a) dal ROCHE ot alii (1971a) considerarem que o controle dos dois ácidos graxos seja efetuado a nivel de desnaturaçăo de oleato. Em estudos dos teores de b́leo nos cloroplastos do escutelo e nas mitocondrias de células das raizes, VÖRÖsBARANYI (1981) observou que o metabolismo ou biosintese dos lípideos e particularmente a sintese do ácido linoleico depende de iluminação.

A degradação dos lipideos ocorre através da ação dos glioxissomos ou microcorpos que são responsáveis em levar os produtos catabólicos (acetil coenzina A) até a gluconeogenesis. Os glioxissomos săo constituidos das enzimas catalase, malato sintetase e isocitrato liase. Apesar da grande diferença no teor de lipidios das linhagens "lllinois High Oil" IHO (20\%) e "Illinois Low Oil" - ILO (0,8\%), nāo foi detectada grande diferença entre suas populaçōes de glioxissomos e atividades da catalase e malato sintetase. A atividade da isocitrato liase foi duas vezes maior nas sementes de IHO, em relaçăo a ILO (TSAFARIS \& SCANDALIOS, 1983a e TSAFARIS \& SCANDALIOS, 1983b). A mais alta atividade da isocitrato liase das sementes com alto teor de lipideo não foi considerada uma consequência do lipideo em si, e, sim, devido à ligação entre genes controlando a atividade do isocitrato liase e aqueles que controlam o teor de lipideo (TSAFARIS \& SCANDALIOS, 1983a).

A qualidade de um lípideo é determinada pela proporção e o grau de insaturação (indice de iodo) dos vários ácidos graxos que o compoem, bem como da posição relativa dos ácidos graxos no triglicerideo (QUACKENBUSH, 1961; PONELEIT \& BAUMAN, 1970; ROCHE et alii, 1971a; ROCHE et alii, 1971b e PAMIN et alii, 1986). Os óleos com maior percentagem de ácidos graxos de cadeias longas, tendo duplas ligaçőes estruturais são mais insaturados e mais desejáveis para a nutriçăo humana além de serem mais fáceis de refinar. Um óleo de alta qualidade tem uma proporçáo relativamente alta de ácido linoleico e menores quantidades de ácido palmitico e esteárico (PONELEIT \& BAUMAN, 1970 e PAMIN et alii, 1986).

A maioria dos estudos de composição do b́leo em ácidos graxos revelaram uma correlação negativa entre os teores de ácido oleico e linoleico no óleo do grão do mi- 
Iho (PONELEIT \& ALEXANDER, 1965; CURTIS et alii, 1968; PONELEIT \& BAUMAN, 1970; JELLUM, 1970; ROCHE et alii, 1971a; WEBER \& ALEXANDER, 1975; JELLUM, 1984 e JELLUM \& WISTTRON, 1984), cuja magnitude pode chegar próximo de 1,0 ( $r=-0,99)$, como observado por VÖRÖSBARANYI (1981). Foi observada também uma correlação negativa entre teor de óleo de todo gråo com os teores de ácido linoleico e palmítico (QUACKENBUSH, 1961; CURTIS et ali, 1968 e PONELEIT \& BAUMAN, 1970) enquanto os teores de ácidos esteárico e oleico foram positivamente correlacionados com o conteúdo de óleo (CURTIS alii, 1968 e PONELEIT \& BAUMAN, 1970). No entanto, nåo foi detectada nenhuma correlaçăo entre rendimento de grãos e a composição de ácidos graxos do óleo (PAMIN et alii, 1986).

O teor e a composição do óleo do grão de milho podem ser afetados pelo local, época e ano de plantio, posiçăo da espiga na planta (primeira ou segunda espiga) e pela posição do grão na espiga (base, meio e ponta), mas nenhum destes fatores, atuando só ou em conjunto,exercem influência tão marcante quanto os fatores genéticos (JELLUM \& MARION, 1966; e JELLUM, 1967).

Parece que existe uma certa relação entre os genes opaco-2 $\left(0_{2}\right)$. floury2 (fl/2), sugary-2 ( su 2 ) waxy $(w x)$ com teores e composição do b́leo do milho. Foi observado que a presença do gene opaco-2 ou floury-2 aumenta o teor de óleo nos grăos, no entanto esta maior percentagem pode não ser significativa se considerarmos o rendimento em óleo (kg/ha), tendo em vista a redução de peso do grão, que normalmente está associada a estes genes (ARNOLD et alii, 1974; MEIRA, 1975; ARNOLD et alii, 1977 e MARTINIELLO ef alii, 1978). A presença do gene $\mathrm{Su}_{2}$ aumenta a percentagem de óleo do embrião e do endosperma (GLOVER \& TOSELLO, 1973; ROUNDY, 1976) e o gene wX afeta a composição dos ácidos graxos destes dois componentes do grão (MDSTROM \& JELLUM, 1984).

Há considerável variabilidade genética para todos os componentes do óleo de milho (QUACKENBUSH, 1961; PONELEIT \& BAUMAN, 1970 e PAMIN et alii, 1986) e também uma correlação negativa, embora baixa, entre os ácidos insaturados (linoleico e oleico) e os ácidos saturados (palmítico e esteárico), assim é possivel melhorar a qualidade através da seleção para ácidos insaturados (QUACKENBUSH, 1961 e PONELEIT \& BAUMAN, 1970). A falta de correlaçăo entre rendimento e composiçăo do bleo sugere que ambas as caracteristicas podem ser simultaneamente melhoradas (PAMIN et alii, 1986). 


\section{Fatores que afetam a percentagem do óleo em milho}

\subsection{Efeito ambiental}

Os resultados dos primeiros trabalhos de seleção para óleo de milho realizados na variedade "Burr's White" revelaram que o ambiente exercia influência no teor de óleo, embora nao houvesse definição de quais fatores ambientais e qual a influência de um fator isolado na composição química do grão (HOPKINS, 1974). Somente bem mais tarde é que os componentes ambientais tais como ano, local, adubação, época de plantio, densidade de plantio e temperatura foram isolados e relacionados com a componente de variaģão genética (SPRAGUE \& BRIMHALL, 1949; SPRAGUE \& BRIMHALL, 1950; JELLUM \& MARION, 1966; JELLUM, 1967; PONELEIT \& BAUMAN, 1970 e MEIRA, 1975).

Além do teor de óleo que em alguns casos é intensamente influenciado pelo ambiente (MENDES, 1972), a composição do óleo em ácidos graxos também sofre influência deste fator (JELLUM \& MARION, 1966; PONELEIT \& BAUMAN, 1970). Assim os locais favoráveis a altos teores de lipídeos tendem a produzir óleo com mais ácido oleico e com me nores teores de acido linoleico. De forma semelhante ao local, o ano exerce influência significativa na qualidade do óleo do grão de milho (JELLUM \& MARION, 1966).

\section{Efeito da fonte polinizadora}

Existem várias formas de isolar e assim avaliar o efeito da fonte polinizadora sobre o conteúdo de óleo. Este isolamento foi obtido através de genes marcadores, ou seja, aqueles que afetam a coloração do endosperma da semente, por MILLER \& BRIMHALL (1951) e CURTIS et ali(1956), por meio da polinizaçăo dirigida com pais contrastantes para teor de óleo (ALEXANDER \& LAMBERT, 1968) e, ainda, através do desenvolvimento de sementes de polinização cruzada e autofecundada provenientes de uma mesma planta (BATISTA 
\& TOSELLO, 1982). Os resultados mostraram que a fonte polinizadora possui pequeno, mas consistente efeito sobre o conteúdo de óleo da semente de milho. Portanto nos estudos de conteưdo de b́leo do grăo necessita-se de polinização controlada. O não controle da polinizaçáo pode acarretar uma determinaçăo errónea do conteúdo de lipideo, prejudicando a avaliaçăo das progênies para a seleção visando a alteração do conteúdo de óleo.

O efeito da fonte polinizadora, em relaçáo a energia de b́leo produzida foi estudada por ALEXANDER \& LAMBERT (1968), que obsenaram que plantas polinizadas por uma fonte de baixo teor de óleo produzirá significativamente menos caloria de óleo, do que as polinizadas por fontes de alto óleo.

O termo xenia é definido como a influência do grão de pólen no embriáo e no endosperma e metaxenia quando a influéncia é sobre o fruto ou semente (BRINK \& COOPER, 1947; ALLARD, 1971). Considerando que o grăo de milho é um fruto com uma semente ou cariopse e que o pólen afeta o teor de óleo em todo gráo (embriáo mais endosperma), o termo metaxenia seria mais adequado para definir a influência do pólen no teor de b́leo do gråo, embora em alguns trabalhos seja usado o termo xenia (RUSCHEL, 1972).

O efeito da metaxenia foi relatado por muitos pesquisadores (MILLER \& BRIMHALL, 1951; CURTIS et alii 1956; ALEXANDER \& LAMBERT, 1968; GARWOOD et alii, 1970 e RUSCHEL, 1972), dal a se considerar que o teor de óleo nos grãos de milho é determinado principalmente pelo genótipo da semente.

\section{Efeito da posiçáo da espiga na planta e dos gráos na espiga}

A posição da espiga na planta não tem efeito sobre os teores de ácidos palmítico, esteárico e linolenico, no entanto a espiga superior (situada no topo), apresenta maior teor de ácido oleico, menor teor de ácido linoleico e maior conteúdo de óleo nos gráos quando comparada com a outra espiga (JELLUM \& MARION, 1966 e JELLUM, 1967). Sendo estas diferenças pequenas e na maioria das vezes náo significativas, os autores concluiram não haver na prática diferenças no teor e qualidade do óleo dos grăos de diferentes espigas da planta. 
O efeito da posição do grăo dentro de uma espiga sobre o conteúdo de óleo na semente foi determinado por LAMBERT et alii (1967) e em relação a qualidade deste óleo foi verificado por JELLUM (1967). Em média, os gráos da base, parte central e ápice apresentaram respectivamente 5,0,5,3 e 4,7\% de bleo. Embora os grăos da posiçăo mediana tivessem maior conteúdo de óleo, os grăos da base apresentaram maior quantidade desta substância, devido ao seu maior peso (17 mg comparado com $14 \mathrm{mg}$ dos gráos do centro e $13 \mathrm{mg}$ dos gráos do ápice). A diferença no conteúdo de óleo dos gráos situados nas diferentes posiçóes da espiga se deve principalmente a efeitos esporofiticos (LAMBERT et alii, 1967).

A posição do grăo dentro da espiga influencia mais os teores de ácido oleico e linoleico do que o conteúdo do ácido palmítico. De uma forma geral, a proporçăo dos ácidos palmítico e linoleico aumenta linearmente da base para o ápice da espiga, enquanto diminui a do ácido oleico. Estes efeitos foram observados em linhagens, mas não em híbridos simples (JELLUM, 1967).

Uma vez que o conteúdo e qualidade do bleo dos grăos de milho podem ser influenciados pela posiçăo do grăo na espiga, sugere-se o uso de sementes da posição mediana da espiga em estudos de seleção de grăos individuais. Para se obter amostra representativa da espiga deve-se usar fileiras inteiras de grãos para retirada de amostras (JELLUM, 1967; LAMBERT et alii, 1967).

\subsection{Efeito matemo}

Considerando que o grăo de milho é composto por três tipos de tecidos geneticamente distintos, o pericarpo de constituiçåo exclusivamente maternal com o núcleo contendo número diploide de cromossomos (2n), o endosperma e a aleurona com núcleo triploide $(3 n)$, sendo $2 n$ proveniente da parte materna e $n$ da fonte polinizadora e o embriáo com núcleo diplóide (2n), em que $n$ cromossomos foram fomecidos pelo pai e $n$ pela máe (CURTIS et alii, 1956), que os sitios primários para a síntese do bleo såo as mitocondrias e os cloroplastos (STUMPF \& JAMES, 1963) e que o ATP, $M n^{++}$, coenzima A, acetatos e glicerol e outros componentes que participam da síntese do óleo (BARREN et alii, 1961; HAWKE \& STUMPF, 1965) sáo fornecidos pela planta que produzirá a semente, era de se esperar efeitos citoplas- 
máticos e ou matemos no conteúdo e composição do óleo. Mas como a atividade de síntese de ácido graxo é govemada principalmente pela quantidade de componentes cedidos pela planta, o genótipo matemal pode controlar o conteúdo de óleo da semente, sem apresentar efeitos citoplasmaticos significativos (SINGH \& HADLEY, 1968).

Na maioria dos estudos de teor de óleo em grãos de milho, observou-se um acentuado efeito matemo (MILLER \& BRIMHALL, 1951; CURTIS et alii, 1956; JELLUM, 1966; GARWOOD et alii, 1970 e BATISTA \& TOSELLO, 1982), embora haja resultado mostrando pequena influência matemal (MILLER et alii, 1981). A influência matema pode ser detectada a nível de percentagem de óleo no germe, na proporção do germe em relação a semente toda e a nivel de qualidade do óleo (CURTIS et alii, 1956; JELLUM, 1966; GARWOOD et alii 1970 e PONOLEIT \& BAUMAN, 1970) e seu efeito é muito maior quando comparado ao efeito citoplasmático (GARWOOD et alii, 1970 e PONELEIT \& BAUMAN, 1970).

O efeito matemo no teor de óleo de grãos de milho foi demonstrado de uma forma simplificada por MILLER \& BRIMHALL(1951),através do cruzamento da linhagem "Illinois Low Oil" (ILO), usada como fêmea, com a linhagem "Illinois High Oil" (IHO), resultando individuos que apresentavam teores médios de bleo em torno de 3,25\%, enquanto o cruzamento reciproco, tendo como mãe a linhagem com alto teor de óleo, produziu descendentes com teores médios de óleo de 6,0\%.

A influência da planta de milho na qualidade de sua semente é variável e depende do ácido graxo analisado e do genótipo usado. De modo geral o oléico e o linoleico são os ácidos graxos mais influenciados pela planta mãe (CURTIS et alii, 1956 e JELLUM, 1966).

Apesar do endosperma apresentar uma proporção de dois para um de genes matemos para paternos, a influência matema sobre o conteúdo de óleo do endosperma é menor do que aquela do germe (CURTIS et alii, 1956).

O isolamento do efeito materno foi normalmente obtido através de avaliaçōes de cruzamentos reciprocos (JELLUM, 1966; PONELEIT e BAUMAN, 1970). Ele foi também estudado por meio de comparaçóes pareadas entre o conteúdo de óleo da mesma espiga, 
tendo diferentes machos como pai (MILLER \& BRIMHALL, 1951) ou ainda através da avaliação de sementes autofecundadas e de polinização livre (BATISTA \& TOSELLO, 1982).

\section{Genes envolvidos com o conteuido de bleo em milho}

A maioria dos trabalhos sobre herança quantitativa do conteúdo de bleo em grăos de milho evidenciou que a variância aditiva é o principal fator que afeta o controle desta caracteristica (SPRAGUE \& BRIMHALL, 1949; EL ROUBY \& PENNY, 1967; LENG, 1974; DUDLEY et alii, 1977; MILLER et alii, 1981), mas năo existe concordância em relaçăo a variância dominante do conteúdo de b́leo. Enquanto os estudos envolvendo as linhagens "illinois High Oil" (IHO) e "lllinois Low Oil" (ILO), resultantes da seleção divergente para teor de óleo da variedade "Burr's White" mostraram evidências de efeito de dominância e, portanto, atribuiramse, importåncia a genes de ação dominante (SPRAGUE \& BRIMHALL 1949; MORENO-GONZALEZ et alii, 1975 e DUDLEY, 1977), os trabalhos com a variedade "Reid Yellow Dent", onde as estimativas de variâncias de domináncia obtidas pelo delineamento I de Comstock e Robinson não defiriram de zero, levaram a conclusão de que os genes de ação dominante năo foram importante para a percentagem de óleo (MILLER et alii, 1981).

MORENO-GONZALEZ et alii (1975) e DUDLEY (1977),estudando linhagens resultantes da seleçåo divergente para teor de bleo e proteina, respectivamente na $68^{\mathrm{a}}$ e 76ª geraçōes de seleção em Illinois, observaram que alguns cruzamentos exibiram dominância para alto óleo, em outros o dominante era o baixo teor de óleo e que próximo da metade dos loci que diferenciam o teor de óleo das linhagens de alto teor de óleo, das linhagens de baixo teor de óleo mostraram algum grau de domináncia. Resultados semelhantes foram obtidos por PONELEIT \& BAUMAN (1970), através de cruzamentos dialélicos de nove linhagens, reciprocos e seus $F_{2}$ ( o material apresentava variação no teor de bleo de 3-7\%) e por SPRAGUE \& BRIMHALL, (1949), com sete linhagens (cinco resultantes da seleçăo divergente de Illinois e duas de lowa) e as respectivas geraçóes $F_{1}, F_{2}, R C_{1}$ e $R C_{2}$. 
Foi demonstrado que o componente de variância aditiva possui muitos loci com ligaçăo completa e entre os loci dominantes ocorre falta de ligaçăo, indicando que os genes com ação dominante estão distribuidos ao longo de todo o genoma em distâncias tais que possam ser herdados independentemente (MORENO-GONZALEZ of ali, 1975). Estudo em 76 geraçбos de seleção divergente para teor de óleo na variedade "Burr's White", revelou que dentro de sete geraçбoes nâo houve nenhum efeito apreciável da ligação gênica, nas linhagens "Illinois High Oil" e "Illinois How Oil" (DUDLEY, 1977).

O teor de óleo nos grăos de milho é uma caracterlstica poligênica que depende basicamente da proporção do germe em relação ao grão e do conteúdo de óleo do embriāo (SPRAGUE \& BRIMHALL, 1949 e MILLER \& BRIMHALL, 1951). O número de genes envolvidos neste sistema ainda năo está bem definido. SPRAGUE \& BRIMHALL (1949) encontraram de $20-40$ genes influenciando o teor de óleo; o trabalho de DUDLEY (1977) estimou em 54 este número. Deve-se acrescentar, ainda, que estes dois resultados foram obtidos para os mesmos materiais, ou seja, linhagens resultantes da seleçăo divergente para óleo de Illinois, portanto, pode não ser aplicado ao milho irrestritamente.

Devido a natureza poligénica do conteúdo de óleo, era de se esperar que alguns destes genes apresentassem algum efeito pleiotrópico. Assim, o tratamento de linhagens de milho com agente mutagénico etil metano sulfonato (EMS), provocou mutaçסes recessivas, cujos portadores apresentavam menores teores de bleo nas sementes. Estas, na geração $\mathrm{M}_{2}$, resultaram em sementes albinas, sugerindo-se desta forma que o gene loc (recessivo) possa ser um gene regulador que se expressa no embrião, em sua forma recessiva homozigota, como uma severa redução no teor de óleo, afetando os cloroplastos dos tecidos esporofíticos, levando a produção de sementes albinas (PLEWA, 1979).

Também é esperado que muitos dos genes que controlam o teor de óleo estejam ligados a fatores relacionados a outras caracteristicas importantes da planta, gerando correlaçōes positivas ou negativas em diversas intensidades. Assim, foi detectado por TSAFA- 
RIS \& SCANDALIOS (1983), que os genes que controlam os niveis de isocitrato liase, enzima que compठe os glioxissomos, estáo ligados áqueles que controlam o teor de lipidios, e por ROUNDY (1976) que o gene sugary-2( $\left(\mathrm{su}_{2}\right)$ quando presente, invariavelmente, provoca aumentos do teor de bleo em linhas com alto ou baixo teor de bleo.

\subsection{Genes ervolvidos com os ácidos graxos}

Estudando a quantidade e qualidade do óleo em cruzamentos dialélicos, PONELEIT \& BAUMAN (1970) observaram que, além da variância aditiva, a variância de dominância é um fator importante no controle do conteúdo dos ácidos palmítico, esteárico, oleico e linoleico do óleo de milho. Empregando oito cruzamentos reciprocos e suas linhagens puras parentais; JELLUM (1966) mostrou uma diversidade de açåo génica para os ácidos graxos, de acordo com o cruzamento e o ácido graxo considerado.

ROCHE et alii (1971a), em estudos genéticos do ácido linoleico através de classes fenotipicas em populaçōes $F_{1}, F_{2}, F_{3}, R C_{1}$ e $R C_{2}$ oriundas dos cruzamentos $I H O x$ R84, R84 x C103 e C103 x IHO concluiram que a diferença entre as linhagens IHO e R84 é determinada por um simples alelo exibindo quase completa dominância e que as linhagens $\mathrm{HO}_{\mathrm{e}}$ R84 possuem os genótipos Ln/n e In/ln respectivamente. A R84 difere da C103 por um simples alelo com dominância incompleta. Do cruzamento entre $\mathrm{IHO} \times \mathrm{C} 103$ e as respectivas populaçбes segregantes, concluiutse que a herança do ácido linoleico está associada pelo menos a dois loci génicos. Em trabalho semelhante com cinco linhagens, WEBER (1983) observou que mais de um locus génico parecia estar envolvido no estabelecimento do ácido linoleico. Considerando a correlaçăo negativa entre ácido linoleico e oleico e que na biosintese de ácidos graxos em sementes de plantas superiores o oleato é desnaturado para linolato (ROCHE et alii, 1971a e ALEXANDER \& CREECH, 1977), sugere-se que o controle genético destes dois ácidos seja exercido a nivel de desnaturaç5o de oleato (ROCHE et alii, 1971a).

Em estudos utilizando linhagens contrastantes com relação ao teor de ácido esteárico e suas populaçōes $F_{1}, F_{2}, R C_{1}$ e $R C_{2}$, JELLUM \& WIDSTROM (1983) concluiram que o carater composiçáso de ácido esteárico é controlado essencialmente por um único gene, com dominância para baixo ácido esteárico, havendo no entanto influência de genes modificadores. Embora SUN et alii (1978) concordem que um único gene seja responsável pelo 
conteúdo deste ácido graxo, eles concluiram que a dominância era para alto ácido esteárico. Comparando os dois trabalhos, observa-se que JELLUM \& MDSTROM (1983) efetuaram análises de óleo em grăos individuais e a variaçăo do ácido esteárico foi de 1,41 a 10,15\%, enquanto SUN et alii (1978) analisaram óleo em amostras de grăos que apresentavam variạ̧âo do teor de ácido esteárico muito menor (1,40 a 2,30\%).

A variação genética do óleo do grăo de milho existe sob tres niveis, total de óleo, composição de ácidos graxos e distribuição posicional dos ácidos graxos no trigliceridio. No entanto, o modo de herança da especificidade posicional é desconhecida, supondo-se, que seja determinada por genes de efeitos secundásios ou modificadores (ROCHE et alii, 1971a).

\section{Localizaçáo de genes que controlam o teor de ácidos graxos}

Usando translocaçóes B-A ou técnicas de translocaçóes reciprocas com o gene marcador ceroso (waxy) para assinalar regiōes dos braços de cromossomos que afetam a composiģão dos ácidos graxos do óleo do embrião, foi detectada uma região no braço longo do cromossomo 4 que afeta os teores dos ácidos palmítico, esteárico, oleico e linoleico (JELLUM \& MDSTROM, 1984; WDSTROM \& JELLUM, 1984; SHADLEY \& WEBER, 1986). No braço longo do cromossomo 10 foi localizada outra regiåo que afeta os teores de ácido palmítico e esteárico (SHADLEY \& WEBER, 1986). Os resultados indicaram, ainda, que no braço longo do cromossomo 5 localizam-se genes que afetam os teores de ácido linoleico e a dosagem da composição de ácidos graxos do endosperma (SHADLEY \& WEBER, 1980; JELLUM \& MDSTROM, 1984; SHADLEY \& WEBER, 1986). O braço curto do cromossomo 1 também está envolvido no controle do ácido linoleico (MDSTROM \& JELLUM, 1984).

\subsection{Efeito da endogamia sobre o teor de bleo}

Em estudos dialélicos envolvendo nove raças de milho, seus possiveis

$F_{1}$ 's e o cruzamento duplo US 13, DUDLEY of alii (1977) observaram efeitos significativos da heterose para o conteúdo de óleo. Efeitos heteróticos foram também observados para os ácidos graxos em muitos dos cruzamentos reclprocos, entre linhagens de milho, efetuados por 
JELLUM (1966). Estimativas de heteroses positivas e negativas obtidas através da fórmula $\mathrm{H}=$ F1 - MP (onde MP é a média dos pais) foram obtidas por DUDLEY (1977) no estudo de 76 geraçס̄es de seleção divergente para óleo e proteina.

Considerando os resultados obtidos pela análise direta de sementes autofecundadas em relação àquelas de polinizaçăo livre, BATISTA \& TOSELLO (1982) observaram efeitos de depressão por endogamia de 4,0\% para percentagem de óleo na população ESALQ-VF-1 e de 8,0\% na mesma população melhorada para embrião grande.

\section{Alteraçóes morfo-fisiológicas do gráo resultantes da seleçáo para óleo}

As análises dos diversos constituintes do grăo revelaram que cerca de 85\% do total do óleo estão contidos no germe ou embrião (LENG, 1967 e HOPKINS et alii, 1974). Em vários trabalhos foram observadas correlaçóes positivas entre teor de óleo do grăo e tamanho do embrião e também entre teores de óleo no germe e no grão (BRUNSON et alii, 1948; SPRAGUE \& BRIMHALL, 1949; MILLER \& BRIMHALL, 1951; CURTIS et alii, 1968; RUSCHEL, 1972; GLOVER \& TOSELLO, 1973; RUSCHEL \& BAUMAN, 1973; MILLER et alii, 1981). De um modo geral, os autores concluiram que o aumento no teor de óleo dos grăos de milho depende principalmente do aumento da proporção do embriāo em relaçāo ao grão e da sua concentração em óleo. O fator mais importante, no entanto, depende da concentração de óleo da variedade usada (DUDLEY et alii, 1974), embora muitos autores considerem a proporção do germe em relação ao grão ou tamanho relativo do embrião como o principal fator (MILLER \& BRIMHALL, 1951; RUSCHEL, 1972 ; RUSCHEL \& BAUMAN, 1973).

Baseando-se nestas informaçōes, PATERNIANI (1972) propôs o uso da seleção visual do tamanho relativo do embrião como um critério a ser empregado em programas que visem o aumento do conteúdo de óleo nos grăos de milho. $O$ uso desta técnica possibilitará progressos razoáveis pelo menos nas etapas iniciais de um programa para elevar o conteúdo de óleo.

A eficiéncia da seleção visual do tamanho do embrião no melhoramento do teor de óleo do grão foi estudada por KINOSHITA \& PATERNIANI (1973a) na população Centralmex e por BATISTA (1980) na população ESALQ-VD-2. Os resultados obtidos pelos au- 
tores, no entanto, são divergentes, enquanto BATISTA (1980) concluiu que este sistema de seleçåo foi eficiente para elevar o conteưdo de óleo nos grăos de milho, com ganhos médios de $1,44 \%$ por ciclo em relação à população original, os resultados obtidos por KINOSHITA \& PATERNIANI (1973a) mostraram que o aumento do tamanho do embriåo nåo provocou acréscimo correspondente no teor de óleo da semente, embora a seleçăo tenha sido eficiente para aumentar tamanho do embriåo, com ganho de 3\% por ciclo de seleçăo nesta característica.

Além do embrião,o peso do grão é afetado pela seleção para alto teor de óleo. Mas o efeito de reduçăo no peso do grăo resultante da seleçăo para elevar o teor de óleo em milho só foi verificado a partir de $7 \%$ de óleo nos grăos (SRIWATANAPONGSE \& BAUMAN, 1966); CURTIS et alii, 1968; DUDLEY et alii, 1974; MILLER et alii, 1981), justificando assim a afirmativa de ALEXANDER \& SEIF (1963) de que a redução no tamanho do endosperma, nas variedades de alto teor de óleo, é um fator de importância primária no melhoramento para alto conteúdo de óleo, principalmente quando se pensa em indices de seleção para tal caracteristica.

As mudanças nos pesos da semente, germe, percentagem de b́leo do germe e relação entre peso germe/endosperma, durante o desenvolvimento da semente, foram estudadas por LENG (1967), que chegou às seguintes conclusōes: a proporção em peso do germe em relação ao grăo todo, aumenta do inicio de sua formação (20 dias após o florescimento) até próximo a maturidade do grão (sete semanas mais tarde); o teor de óleo no germe passa de aproximadamente $38 \%$ (inicio da formaçåo do germe) para $54-56 \%$ (quarta semana de desenvolvimento do grão), permanecendo quase constante dal para frente. $O$ conteúdo de b́leo do grão aumentou quase da mesma forma que a proporçăo do germe e só atingiu o nivel máximo sete semanas após a polinização.

Tendo em vista que o teor de óleo dos grãos de milho é uma função direta do tamanho relativo do embriāo e de seu conteúdo em óleo, LENG (1961) demonstrou que os métodos mais precisos para a predição de respostas a seleção para a percentagem de óleo são os que consideram os componentes proporçăo do germe em relação ao grăo e percentagem de óleo do germe.

A seleção para alto teor de b́leo no embriāo pode provocar aumentos no peso total do embriăo, na percentagem de germe em relação ao grăo, no tamanho e na percen- 
tagem de bleo do germe e reduçŏes no peso do endosperma e da semente, promovendo ainda um acréscimo na velocidade do desenvolvimento do embriáo durante a germinaçăo (SRIWATANAPONGSE \& BAUMAN, 1966 e CURTIS et ati, 1968). Por isto, a percentagem de óleo do germe pode ser usada como uma medida indireta do indice de qualidade de sementes individuais do milho (SRIWATANAPONGSE \& BAUMAN, 1966).

\section{Variabilidade genética do conteúdo de oleo em milho}

A maioria dos trabalhos em que se estimam variâncias genéticas o fazem exclusivamente com a finalidade de obtençăo da variância aditiva com os objetivos de previsão de ganhos em programas de melhoramento do teor de óleo de determinada populaçáo (BAUMAN et alii, 1965; MIRANDA et alii, 1976; TOSELLO \& GERALDI, 1980a; BIANCO, 1984; ZIMBACK, 1985; ZANOTTO, 1986 e PAMIN et alii, 1986). Os trabalhos que envolvem estimativas de variâncias de dominâncias, bem como interpretaçóes genéticas dos valores assumidos pelas variâncias em relação ao tipo de ação gênica envolvida, são mais raros (EL ROUBY \& PENNY, 1967; MORENO-GONZALES ef alii, 1975 e MILLER et alii, 1981).

Os valores de variância de dominância observados por EL ROUBY \& PENNY (1967) e MILLER et alif (1981), respectivamente em uma variedade sintética do cruzamento "Ford"s High Oil" x "lowa High Oil" 'e nos ciclos zero e cinco de seleção da variedade "Reid Yellow Dent" não diferiram de zero, indicando que os genes de ação dominante não foram importantes para a percentagem de óleo; no entanto, aqueles observados por MORENO-GONZALES ot alii, (1975)no cruzamento de linhagens de alto e baixo teor de b́leo resultante da 68ª geração de seleçăo divergente para o teor de óleo de lllinois, foram diferentes de zero, levando a obtenção de um grau médio de dominância (a) igual a 0,508 para $F_{2}$ e 0,681 para $F_{6}$, mostrando assim a importância da ação gênica dominante no teor de óleo.

$\mathrm{Na}$ Tabela 3 - Apendice, são apresentados resultados de estimativas de variância aditiva ( $\hat{\sigma}_{\hat{A}}^{2}$ ), variância de dominância ( $\left.\hat{\sigma o}_{\mathrm{D}}^{2}\right)$, razáo entre variância de dominância e variância aditiva ( $\left.\hat{\sigma}_{\bar{D}}^{2} / \hat{\sigma} \underset{A}{2}\right)$, média $(\bar{x})$, herdabilidade no sentido restrito ao nivel de planta $\left(h^{2}\right)$, herdabilidade no sentido restrito ao nivel de médias de parcelas, coeficiente de variaçăo genética $(\mathrm{CVg})$, índice de variação $(\mathrm{b}=\mathrm{CVg} / \mathrm{CVe})$ e o progresso esperado com a seleçăo (Gs) para o teor de óleo no grão de milho, em várias populaçరీes, obtidas por diferentes autores. Observa- 
se que a variancia aditiva ( $\hat{\sigma}_{\hat{A}}^{2}$ ) para o teor de óleo variou de $1,40 \times 10^{-2}(\%)^{2}$ obtida por MILLER et alii (1981) no ciclo zero da variedade "Reid Yellow Dent" a 155,00 × 10-2(\%) observado por MORENO-GONZALES et alii (1975) em uma popúlação $F_{2}$, do cruzamento entre linhagens de alto e baixo teor de óleo. A herdabilidade a nivel de plantas apresentou valores que variaram de 9,85 a 85,80\%. A variação do ganho de seleção foi inferior áquela da herdabilidade, pois o menor valor do ganho 1,03\% é 9,21 vezes inferior ao maior valor obtido por MIRANDA et alif (1976) que é de 9,49\%, enquanto a diferença entre os extremos da herdabilidade ao nivel de média de progênies foi 12,60 .

MIRANDA et alii (1976) trabalhando com 300 familias de meios irmâos da variedade Centralmex HS IV-MI observaram que a variância dentro de familias ( $\hat{\sigma} \frac{\hat{d}}{\mathrm{~d}} \mathrm{em}$ relação ao teor de óleo foi 3,3 vezes maior que a variância entre progênies. Relaçăo de $\hat{\sigma} \mathcal{d}^{2} \hat{\sigma}{ }_{p}^{2}$ maior do que 1,0, foi também observada por ZIMBACK, 1985 e ZANOTTO, 1986. No entanto, BIANCO (1984) observou proporçáo inferior a 1,0 entre variância dentro de famílias e variancia entre familias.

Os valores de $\hat{\sigma} \hat{A}_{A}^{2}=0,8220 \pm 0,1560(\%)^{2} ; \hat{\sigma}_{D}=0,0870 \pm 0,088(\%)^{2}$; $\hat{\sigma}^{2} \widehat{\sigma_{A}^{2}}=0,1897$ e $h^{2}=76,7 \%$ foram apresentados como estimativas médias para estes parâmetros da percentagem de óleo, indicando assim que esquemas simples de seleçåo devem conduzir a bons resultados no melhoramento de óleo em milho (HALLAUER \& MIRANDA FILHO, 1981).

Em quase todas as populaçסes estudadas foi detectada suficiente variabilidade genética para obtençăo de progressos significativos em programa de melhoramento para o teor de óleo; esta variabilidade náo foi exaurida mesmo depois de 76 ciclos de seleçáo para teor de óleo (DUDLEY et alii, 1974).

\section{Variabilidade genética em caracteres da planta do milho}

Levantamentos realizados por HALLAUER \& MIRANDA FILHO (1981) em 99 trabalhos em cinco tipos de populaçőes mostraram variabilidade genética aditiva suficiente para o melhoramento do rendimento de grãos. Estes autores observaram valores médios de $468,8(g / p t a)^{2}$ e $279,9(g / p t a)^{2}$, respectivamente para a variância aditiva ( $\left.\hat{\sigma}_{\hat{A}}^{2}\right)$ e a variáncia de domináncia ( $\hat{\sigma}_{\mathrm{D}}^{2}$ ). 
Estimativas de variância aditiva ( $\left.\hat{\sigma}_{\hat{A}}^{2}\right)$, variáncia de domináncia ( $\left.\hat{\sigma}_{D}^{2}\right)$, razáo entre variância de domináncia e variáncia aditiva ( $\hat{\sigma} \mathcal{Z} / \hat{\sigma} \mathcal{A})$, bem como herdabilidade ao nivel de plantas $\left(h^{2}\right)$ para o rendimento de grăos em g/pta, obtidas por diferentes pesquisadores em populaçóes brasileiras de milho, săo apresentadas na Tabela 4 - Apêndice. 0 maior valor assumido pela variância aditiva foi de $879(\mathrm{~g} / \mathrm{pta})^{2}$, observado por SOARES FILHO (1987) na populaçăo Piranăo VF-1 B, enquanto o menor valor deste parâmetro foi $54(\mathrm{~g} / \mathrm{pta})^{2}$ obtido por BIGOTO (1988) na população ESALQ PB-1 IV. VENCOVSKY et alii (1988) obtiveram valores médios (médias de 58 estimativas) de variância aditiva de $309(\mathrm{~g} / \mathrm{pta})^{2}$ e de herdabilidade de 11,00\% . Na Tabela 4 - Apéndice, obsena-se ainda que a herdabilidade do rendimento de gráos é sempre baixa $(25,12-1,85 \%)$ e que estimativas de variância de dominância sáo pouco frequentes.

Nas populaçб̄es brasileiras de milho braquittico avaliadas, a variância aditiva para o caráter altura de planta (Tabela 5-Apéndice) esteve entre 698 e 94 (cm/pta) ${ }^{2}$ valores estes obtidos respectivamente por SOARES FILHO (1987) e ZANOTTO (1986). Com exceção das herdabilidades 13,38 e 21,39\% obtidas por BIGOTO (1986) e 26,0\% obtida por BENITEZ TORRES (1986), todos os outros valores de herdabilidade para altura de plantas foram de médios a altos. Uma variação semelhante nos valores de variáncia aditiva e uma alta herdabilidade ao nivel de plantas foram observadas no caráter altura de espiga (Tabela 5 - Apéndice). Esta semelhança dos valores de variáncias e de herdabilidade é, em parte, explicada pela alta correlaçáo existente entre os caracteres altura de planta e altura de espiga.

A ocorrência de variâncias genéticas negativas quando detectadas se deve aos seguintes fatores: 1) modelo genético inadequado; 2) erro de amostragem; 3) delineamento experimental inadequado (efeitos de competiçáo entre individuos); 4) ordenaçăo de cruzamentos (HALLAUER \& MIRANDA FILHO, 1981 e LINDSEY et aii, 1962). Um ou vários destes fatores podem ter ocorrido, levando a obtençăo da variância aditiva negativa $-2,00$ (cm/espiga) ${ }^{2}$ obtida por PAL et alii (1986) para comprimento de espiga. Variáncias negativas de dominância săo mais frequentes do que variâncias aditivas negativas (BRIDGES \& KNAPP, 1987). Apesar dos valores negativos de variáncias observados para o caráter comprimento de espiga, os valores médios das estimativas destes parâmetros obtidos por HALLAUER \& MIRANDA FILHO (1981) foram de $152,4 \times 10^{-2}\left(\mathrm{~cm} /\right.$ espiga) ${ }^{2}$ para $\hat{\sigma} \frac{2}{A}, 50,40 \times 10^{-2}\left(\mathrm{~cm} /\right.$ espiga) ${ }^{2}$ para ô 2 e $38,10 \%$ para $\frac{2}{x}$ (Tabela 6 - Apéndice). 
O maior valor assumido pela variância aditiva do diâmetro de espigas foi de $8,14 \times 10^{-2}$ (cm/espiga) ${ }^{2}$ no cruzamento entre as populaçóes Entrelaçado $\times$ ESALQ PB-1, obtido por SANTOS (1985). O valor médio da ô 2 foi de $4,60 \times 10^{-2}$ (cm/espiga) ${ }^{2}$, em 35 estimativas obtidas por HALLAUER \& MIRANDA FILHO (1981). Excetuando os valores de herdabilidade média para diámetro de espiga de 7,19 e 13,6\% obtidos respectivamente por SOARES FILHO (1987) e VARGAS ot alii (1982), todas as demais herdabilidade foram acima de $32,00 \%$ (Tabela 7 - Apéndice).

Existe uma grande diferença entre o maior e o menor valor da estimativa da $\hat{\sigma}_{\hat{A}}^{2}$ para o caráter diâmetro do sabugo (o maior valor é 33,31 vezes o menor valor), no entanto os valores assumidos pela herdabilidade média teve uma variação muito menor, haja visto que entre os valores extremos existe uma proporção de 11,92 apenas, uma vez que todas as herdabilidades médias para diâmetro de sabugo foram de médias a altas (Tabela 8 - Apêndice).

Com um valor mínimo de $4,41 \mathrm{~g}^{2}$ e um máximo de $14,28 \mathrm{~g}^{2}$ pode-se observar, pelos dados da Tabela 9 - Apêndice, pequena variação nos valores da variância aditiva, para peso de 100 grăos nas diferentes populaçóes. Os valores da herdabilidade média variaram de 34,12\%, obtido por QUEIROZ (1969) em um composto dentado branco, a 79,87\%, obtido por MOTA (1974) na população Centralmex.

A $\widehat{o}_{\hat{A}}^{2}$ para o número de grãos por fileiras variou de 68,00 a 220,87 (grãos/fileira) ${ }^{2}$ e a herdabilidade média do caráter, em todos os trabalhos levantados foi alta (46,50-67,40\%) (Tabela 10 - Apéndice).

O caráter número de fileiras de grãos por espiga apresentou variâncias aditivas, em média, superiores áquelas apresentadas pelo número de grãos por fileiras. No entanto, a média da herdabilidade, do número de grăos por fileira foi superior àquela do número de fileiras por espiga, embora ambas caracteristicas tenham herdabilidade de média a alta (Tabela 10 - Apêndice). 


\section{Relaçáo entre teor de óleo do gráo de milho com outras caracterlsticas da planta}

Existem muitos trabalhos onde procurou-se estudar as possiveis relaçőes entre o teor de óleo do grão ou mesmo entre o teor de óleo do germe com outras características da planta do milho. Os caracteres rendimento de espigas ou de gráos, peso de 100 gráos, volume e densidade dos grăos, altura de espiga e altura de planta, percentagem de proteina e de triptofano no gráo e energia do grão foram os mais empregados nestes estudos.

A correlaçăo entre teor de óleo no milho e o rendimento de grăos foi estudada por muitos autores, com resultados contraditórios. Alguns experimentos revelaram haver uma correlação positiva, embora baixa, entre teor de óleo e produtivade em grăos (MILLER \& BRIMHALL, 1951; GUPTA et alii 1975; MILLER et alii 1981; BIANCO, 1984 e ZIMBACK, 1985), enquanto outros encontraram correlaçōes negativas (baixa a média) entre estas duas características (EL ROUBY \& PENNY, 1967; ALEXANDER et alii, 1970; DUDLEY et alii 1977; TOSELLO \& GERALDI, 1980b e BIANCO, 1984). Apesar destes resultados contrastantes MILLER \& BRIMHALL (1951), trabalhando com teores de oleo e rendimentos que variavam de 5,2 a $8,0 \%$ e 3.400 a $5.700 \mathrm{~kg} /$ ha respectivamente e uma correlaçáo positiva $(r=0,41)$ entre teor de óleo e rendimento de gráos, concluiram que aumentos de até $3 \%$ no teor de óleo pode ser obtido sem afetar a produtividade do material. Na realidade a seleção para alto teor de óleo só é significativa na reduçāo do peso de grãos, quando o conteưdo de óleo atingir limites superiores a 7\% (DUDLEY et alii, 1974; MILLER et alii, 1981). Assim PATERNIANI (1972) mostrou ser possivel elevar o conteúdo de óleo sem reduzir a produtividade dos grăos.

Correlaçăo negativa alta entre o teor de óleo e peso de 100 grăos $(r=-0,85)$ foi observada por DUDLEY et alii (1977) em estudo de populaçőes resultantes da seleção divergente para óleo da variedade "Burr's White". Valores negativos, muito baixos, de correlação entre estas características foram obtidas por ALEXANDER \& SEIF (1963) EL ROUBY \& PENNY (1967), ZIMBACK (1985) e por BATISTA \& TOSELLO (1979)na subpopulação alto óleo da população ESALQ-VD. Nas subpopulaçōes ESALQ-VD original e opaco foi observada correlaçáo positiva baixa entre teor de óleo e peso de 100 grăos (BATISTA \& TOSELLO, 1979 e TOSELLO \& GERALDI, 1980b). Estes resultados suportam a idéia de que existe uma baixa correlaçăo positiva entre o teor de b́leo e o peso de 100 grăos em populaçóes pouco melhoradas para alto oleo. Esta correlaçáo se modifica e passa a ser negativa à:medida que se intensi- 
fica a seleçăo para óleo. Assim, material com 76 geraçbes de seleçăo para alto bleo apresentou alta correlaçáo negativa entre estas duas características.

Estudando a variaçăo genética da composiçăo de ácidos graxos e a percentagem de óleo entre familias de irmáos germanos interpopulacionais (Nebraska B e Nebraska Krug), PAMIN et alii (1986) obsenvaram alta correlaçăo positiva entre rendimento de grăo e rendimento de oleo; resultado semelhante foi obtido por LAMBERT of alii (1967). Isto é facilmente explicável, tendo em vista que o rendimento de grăos é um dos componentes que entram no cálculo do rendimento de óleo. Alta correlação positiva entre teor de óleo (\%) e rendimento de óleo (kg/ha) foi obsenvada por EL ROUBY \& PENNY (1967).

Usando duas subpopulaçőes (original e alto óleo) oriundas da populaçăo ESALQ-VD, BATISTA (1980) observou que em ambas subpopulaçסீes a percentagem de óleo apresentou correlaçáo fenotipica positiva muito baixa com o caracter densidade de gráos. $R e$ sultado semelhante foi observado entre teor de óleo e volume de 100 grãos na ESALQ VD original. No entanto, a populaçăo alto óleo apresentou uma correlaçăo fenotípica negativa baixa, entre os caracteres teor de óleo e volume de 100 grãos. ZIMBACK (1985) observou altas correlaçōes genéticas aditivas negativas entre teor de óleo e densidade de gráos na população de milho dentado braquítico opaco. Os valores assumidos pela correlaçáo fenotípica foram positivos baixos, portanto não divergiram daqueles observados por BATISTA (1980) para estas caracteristicas.

Estudos relacionando teor de bleo com proporçáo do germe em relaçăo ao grăo inteiro foram efetuados por MILLER \& BRIMHAL (1951) em milho de endosperma normal e por RUSCHEL (1972) em milho opaco-2. Em ambos casos observaram-se que estas caractetrísticas estāo positivamente correlacionadas. Obsenvou-se também altas correlaçס̄es positivas entre a porcentagem de óleo do germe com a porcentagem de óleo do gráo e variaçăo independente das características tamanho relativo do germe e percentagem de óleo no germe (MILLER \& BRIMHALL, 1951). Devido à influência do teor de bleo no tamanho relativo do embriåo, no tamanho individual do grăo e principalmente na velocidade das reaçōes durante a germinação, SRIWATANAPONGSE \& BAUMAN (1966) sugeriram o uso do teor de bleo como uma medida indireta da qualidade da semente. 
Baixas correlaçóes positivas entre o teor de óleo e altura de planta e entre teor de óleo e altura de espiga foram obtidas por BIÁNCO (1984) nas populaçbeses Piranão VD-2 e Piranáo VF-1 e por EL ROUBY \& PENNY (1967) na variedade sintética resultante do cruzamento "Ford"s High Oil" $x^{\prime \prime}$ lowa High Oil", levando os autores a concluir que estes caracteres variam independentemente na planta.

A relaçáo entre o teor de óleo e outros componentes do gráo foi bastante estudada. Mais comum ainda sáo os estudos que envolvem a relaçăo entre b́leo e proteina (triptofano, lisina) devido aos aspectos nutricionais (MILLER \& BRIMHALL, 1951; RUSCHEL, 1972; RUSCHEL \& BAUMAN, 1973; BAUMAN, 1975; DUDLEY et alii 1977, TOSELLO \& GERALDI, 1980b; ZIMBACK, 1985; SONG et alii, 1986). Na maioria dos trabalhos onde se correlacionou teor de óleo com conteúdo de proteina obteve-se valores positivos de médios a baixos (MILLER \& BRIMHALL, 1951; BAUMAN, 1975; DUDLEY et alii, 1977 e SONG et alii, 1986); no entanto as correlaçōes genéticas aditivas entre estas caracteristicas, observadas por ZIMBACK (1985), foram de $r_{A}=0,8111$ e $r_{A}=0,8430$ respectivamente para as subpopulaçóes $A$ e $B$ oriundas do composto braquítico dentado opaco-2. A proteina do germe, ao contrário da protelna do gráo ou do endosperma, está negativamente correlacionada com o teor de óleo do germe (RUSCHEL, 1972; RUSCHEL \& BAUMAN, 1973 e BAUMAN, 1975).

Os resultados do estudo da correlaçáo entre conteúdos de óleo e de triptofano no grão sáo contraditórios. Enquanto ZIMBACK (1985) observou valores positivos altos de correlaçáo genética aditiva ( $r_{A}=0,845$ e $\left.r_{A}=1,000\right)$, TOSELLO \& GERALDI (1980b), observaram valores baixos e negativos, apesar de ambos os trabalhos terem sido conduzidos em populaçáo de milho opaco-2. Os valores desta correlaçăo, obtidos por MILLER \& BRIMHALL (1951), foram positivos e medianos.

Envolvendo ainda aspectos relacionados à qualidade do grão, foi observada correlação positiva entre o teor de b́leo no grăo e o teor de lisina também no gráo (BAUMAN, 1975; SONG et alii, 1986) e negativas entre o teor de óleo no grão e o teor de lisina na proteina do endosperma (BAUMAN, 1975) e entre conteúdo de amido e o teor de b́leo do gráo (MILLER \& BRIMHALL, 1951). 
Avaliando a variação genética da composição de ácidos graxos e da percentagem de b́leo em famílias de irmáos germanos intrapopulacionais envolvendo as populaç̋̌es "Nebraska B" e "Nebraska Krug", PAMIN et alii (1986) observaram correlaçбes negativas entre percentagem de b́leo e os teores de ácido linoleico e linolénico, cujos valores foram $r=-0,48$ e $r=0,45$ respectivamente e correlação positiva entre teor de óleo no grão e teor de ácido oleico $(r=0,51)$.

DUDLEY et alii (1977) levantaram tres aspectos a respeito da capacidade de armazenamento energético do milho; 1) concentraçăo de energia no gráo em cal/g de maté ria seca; 2) produção de energia por grão em cal/g; 3) rendimento de energia $\mathrm{Kcal} / \mathrm{ha}$. A produção de energia por grão e rendimento de energia săo positivamente correlacionados com conteúdo de óleo $(r=0,99$ e $r=0,49)$ e com o rendimento de grãos $(r=0,58$ e $r=0,98)$ respectivamente. Eles obsenaram também que o total de energia produzida é mais fortemente influenciada pela produção de grãos do que pela concentração de energia nos grãos.

Estudando a relação entre o conteúdo de bleo e o rendimento em milho usando híbrido simples como fémea, cruzado com linhagens com baixo e alto teor de óleo, ALEXANDER \& LAMBERT (1968) observaram correlaçōes negativas entre calorias de óleo e calorias de carboidratos no grăo polinizado com machos de baixo teor de bleo e positiva muito baixa entre estes caracteres, quando usou machos de alto teor de bleo. Segundo os autores, os resultados obtidos sugerem que a habilidade de uma planta em produzir carboidratos e sintetizar óleo é praticamente independente ou pelo menos independente fisiologicamente.

Usando material resultante do cruzamento entre "Ford"s High Oil" $\mathrm{x}$ "lowa High Oil", EL ROUBY \& PENNY (1967) observaram baixa correlaçáo negativa entre percentagem de óleo e data de florescimento e auséncia de correlaçáo entre o conteúdo de óleo e acamamento. Năo foi também observada correlação entre teor de bleo nos grãos e resisténcia à diploidia nos sintéticos estudados por ALEXANDER \& SEIF (1963).

\section{Métodos de selegáo usados para aumentar o teor de óleo em milho}

O primeiro método usado no melhoramento de óleo em gráos de milho foi de espiga por fileira, que consistia essencialmente na escolha de um grupo de espiga com 
características agronómicas desejáveis, sendo as sementes dessas espigas plantadas em fileiras individuais, obtendo-se assim uma avaliação das progênies das espigas escolhidas. As sementes remanescentes das melhores espigas nos testes de progenies eram misturadas para obtenção da geração seguinte. Este método foi idealizado por C.G. Hopkins e aplicado no meMhoramento divergente para teor de óleo e proteina da variedade "Burr's White" iniciado em Illinois em 1896 (HOPKINS, 1974). Com poucas e raras modificaçర̃es, o método de melhoramento espiga por fileira continuou sendo usado por muitas geraçб̋es de seleção. Resultados da 50, 65 e 70 geraçס̄es são apresentados respectivamente por WOODWORTH et alii (1974), DUDLEY \& LAMBERT (1974) e DUDLEY et alii (1974). O método de seleção espiga por fileira, quando usado no melhoramento do conteúdo de óleo em milho, é equivalente à seleçăo entre famílias de meios irmãos, uma vez que a percentagem de óleo dos grãos é estabelecida pelo genótipo do próprio grão (DUDLEY, 1977).

Vários outros métodos têm sido empregados no melhoramento de óleo em grăos de milho, tais como; seleção massal (EL ROUBY \& PENNY, 1967; PATERNIANI, 1972; RUSCHEL \& BAUMAN, 1973 ; WEBER \& ALEXANDER, 1975); seleção em familias de meios irmãos (RUSCHEL \& BAUMAN, 1973; MIRANDA et alii, 1976; FUNDUIANU \& MOGA, 1980 e MILLER et alii, 1981); seleção em famillias de irmãos germanos (EL ROUBY \& PENNY, 1967; RUSCHEL \& BAUMAN, 1973 ; FUNDUIANU \& MOGA, 1980); obtenção de híbridos através de autofecundação, "top cross" e retrocruzamento (ALEXANDER et alii, 1970); seleção para capacidade geral de combinação (EL ROUBY \& PENNY, 1967), seleção de progênies autofecundadas S 1 (PAMIN et alii, 1986); seleção recorrente (SPRAGUE et alii, 1952); seleção recorrente reciproca (ALEXANDER et alii, 1970).

Utilizando os resultados de 61 geraçōes de seleção divergente para bleo e proteina em milho efetuada em Illinois, LENG (1961) comparou os resultados de ganhos esperados, com ganhos reais obtidos, através de três métodos: 1) Extrapolação da linha de regressão (diferencial de seleção acumulado x percentagem de óleo); 2) uso da fórmula $R=i \hat{o} h^{2}$ (FALCONER, 1964) onde R: é a resposta esperada por geração, i: é a intensidade de seleção, $\hat{\sigma}$ : é o desvio padrão e $h^{2}$ : é a herdablidade; 3) subdivisão do caráter teor de óleo nas componentes tamanho do germe e teor de b́leo no germe. $O$ autor concluiu que o método de previsão de ganho que subdivide o caráter em componentes é o que mais se aproxima do ganho real. 
No entanto, a seleçăo baseada somente no tamanho do embrião pode não ser eficiente no melhoramento do teor de bleo (KINOSHITA \& PATERNIANI, 1973b).

Em programas de melhoramento poderão ser empregadas progénies autofecundadas e ou progénies de polinizaçăo livre, sem grandes alterações no ganho genético a ser obtido. Isto se deve à alta correlação existente entre estes dois tipos de progénies para teor de óleo $(r=0,67)$, observada por BATISTA (1981). A seleçăo no entanto, deverá ser baseada não só nas médias de progénies, mas também em grãos simples, aumentando assim a eficiência dos métodos de melhoramento para óleo (BAUMAN et alii, 1965).

O estudo da eficiência dos métodos de melhoramento foi feito por muitos pesquisadores, através de previsőes de ganhos genéticos (MIILER et alii, 1981; BIANCO, 1984; ZIMBACK 1985; ZANOTTO, 1986) ou por meio de cálculos de ganhos genéticos reais, obtidos ao submeter uma mesma populaçăo a mais de um método de seleçăo para teor de b́leo nos grăos (SPAGUE \& BRIMHALL, 1950; EL ROUBY \& PENNY, 1967; RUSCHEL \& BAUMAN, 1973 e PAMIN ef alii, 1986).

Os ganhos genéticos esperados no teor de b́leo dos grăos através da seleção massal foram comparados àqueles da seleção entre e dentro de famílias de meios irmãos (MILLER et alii, 1981; BIANCO, 1984; ZIMBACK, 1985). Nas populações Piranão VD-2, Piranăo VF-1 e Dentado braquítico opaco-2, observaram-se que os ganhos genéticos esperados pela seleção massal de $10 \%$ em ambos os sexos foi levemente superior à seleção entre (20\%) e dentro (10\%) de progénies de meios irmãos, com sementes remanescentes (BIANCO, 1984 e ZIMBACK, 1985). Na variedade "Reid Yellow Dent", observou-se ganhos genéticos esperados um pouco superiores na seleção entre e dentro de familias de meios irmãos em relação à seleçăo massal, obtendo-se o ganho esperado máximo quando a intensidade de seleção dentro foi maior que entre familias (MILLER et alii, 1981). Esta contradição nos resultados talvez possa ser explicada em parte pela diferença de intensidade de seleção entre e dentro de famílias meios irmãos consideradas na seleçăo da variedade ,"Reid Yellow Dent" em relaçăo ḋquelas assumidas nas populaçōes Piranão VD-2, Piranão VF-1 e Dentado braquítico opaco-2.

A comparação de ganhos genéticos no teor de óleo, obtidos nos diversos métodos de melhoramento, foi feita por muitos autores (SPRAGUE \& BRIMHALL, 1950; EL 
ROUBY \& PENNY, 1967; RUSCHEL \& BAUMAN, 1973; PAMIN et alii, 1986). Com exceção de EL ROUBY \& PENNY (1967), que compararam os ganhos de seleçăo massal com seleçăo recorrente para capacidade geral de combinaçăo, em todas as comparaçőes foram empregadas progénies autofecundadas. Os ganhos genéticos obtidos pela seleçáo massal foram superiores àqueles obtidos pela seleçăo para capacidade geral de combinaçăo para percentagem de óleo, o contrário foi observado quando se considerou o rendimento em óleo em kg/ha (EL ROUBY \& PENNY, 1967). A seleçăo de progénies autofecundadas foi tão eficiente quanto a seleçăo baseada em famílias de meios irmáos ou irmāos germanos (RUSCHEL \& BAUMAN, 1973 e PAMIN et alii, 1986) e 2,6 vezes superior à seleçăo recorrente, em ganhos genéticos para conteúdo de óleo dos grăos (SPRAGUE \& BRIMHALL, 1950). Ganhos genéticos obtidos pela seleçăo de progénies autofecundadas superiores aqueles obtidos por seleçáo de progênies de irmáos germanos foram obtidos por PAMIN et alii (1986) na populaçăo "Nebraska Krug".

Considerando os valores elevados de herdabilidade associados ao conteúdo de óleo e a influência do genótipo do grăo nesta característica, sugerem-se os esquemas simples de seleçăo, com ênfase na seleçăo de grăos individuais, como os métodos mais adequados de melhoramento para óleo em milho (PONELEIT \& BAUMAN, 1970; DUDLEY, 1977 e HALLAUER \& MIRANDA FILHO, 1981). 


\section{MATERLAL E MÉTODOS}

\subsection{MATERIAL}

Foram usadas as populaçōes Piranão VD-2 e Piranão VF-1, que correspondem a versão braquítico das populaçóes ESALQ VD e ESALQ VF respectivamente, obtidas por cruzamentos e retrocruzamentos, usando a variedade Piranão como pai não recorrente e fonte do gene braquítico 2 (br2). Após um retrocruzamento, seguiram-se três geraçбós de cruzamentos ao acaso em lotes isolados. Em cada populaçăo foi praticada uma seleçăo com objetivo de uniformizar a arquitetura (PATERNIANI, 1977). A variedade Piranão usada como pai nāo recorrente, foi obtida a partir de cruzamentos entre Piramex e Tuxpeño (br2) (PATERNIANI, 1973).

As plantas da população Piranão VD-2, caracterizam-se por ser braquíticas e apresentar grande produtividade, espigas relativamente grossas, com grăos amarelos dentados, largos e longos. A populaçāo Piranão VF-1 apresenta plantas braquíticas com boa produtividade, espigas com grăos duros e de cor laranja. As duas populaçб̄es encontram-se no segundo ciclo de seleção entre e dentro de famílias de meio irmāos, para alto teor de óleo (BIANCO, 1984). 
Como testemunhas, foram empregados os híbridos duplos $\mathrm{Ag}-352-\mathrm{B}$ da Agroceres e DEK XL 540 da Dekalb, de porte baixo, que em cultivos comerciais, têm manifestado boas produtividades e caracteristicas agronómicas satisfatórias.

\section{MÉTODOS}

\section{Obtenção das progénies do Delineamento I de Comstock e Robinson}

No ano agricola $1983 / 84$ foram instaladas 150 parcelas (fileira de dez plantas) com sementes da populaçăo Piranão VD-2.Em cada uma destas parcelas, a primeira planta, usada como macho (doadora de pólen), foi cruzada com cinco a seis plantas da mesma parcela, resultando assim progénies de irmáos germanos descendentes de um mesmo macho (Delineamento 1). Os mesmos procedimentos foram tomados em relaçăo à populaçăo Piranão VF-1. Obtiveram-se assim, 364 e 381 progênies respectivamente das populaçōes Piranăo VD-2 e Piranão VF-1.

\section{Execuçăo Experimental}

\section{Campo}

As 745 progénies das duas populaçőes usadas, foram avaliadas no município de Piracicaba, no Campo Experimental da Caterpillar, no ano agricola 1985/86, em solo Podzólico Vermelho Amarelo Distrófico (Tabela 11 - Apêndice). As médias mensais de temperatura mínima e máxima, umidade relativa e de precipitaçăo pluviométrica ocorridas no período de avaliação em campo são apresentadas na Tabela 12-Apéndice.

Usou-se o espaçamento de $1,00 \mathrm{~m}$ entre linhas e $0,20 \mathrm{~m}$ entre plantas. A parcela utilizada foi de $5 \mathrm{~m}^{2}$, onde foram semeadas 25 sementes. Empregou-se o delineamento em látices triplo, sendo as progénies do delineamento I da populaçăo Piranão VD-2, dispostas em três latices $10 \times 10$ e um látice $8 \times 8$. Na avaliação da população Piranão VF-1 usou-se três látices $10 \times 10$ e um látice $9 \times 9$. No início, meio e fim de cada repetiçáo de cada látice eram dispostas as parcelas dos híbridos Ag-352-B da Agroceres e DEK XL 540 da Dekalb.Somente as repetiçóes um e dois foram usadas nas avaliaçb̄es dos caracteres e nas análises estatísticogenéticas.

Foi efetuada uma adubação no sulco com $300 \mathrm{~kg} / \mathrm{ha}$ de fórmula 4-14-8. Posteriormente foram feitas duas aplicações de $150 \mathrm{~kg} / \mathrm{ha}$ de sulfato de amónia. Para o controle de evvas daninhas usou-se o herbicida Primextra, aplicado logo após a semeadura. 
Nas progênies de cada população foram tomados dados de doze caracteres, conforme discriminação mostrada a seguir:

Atura da planta (AP): Distância em centímetros, entre a superfície do solo, contlgua ao colo da planta, e a inserçăo da folha superior, determinada através de régua dividida em unidades de cinco centimetros. Esta medida foi feita em cinco plantas competitivas, tomadas ao acaso dentro da parcela.

Altura da espiga (AE): A medida de AE foi obtida nas mesmas plantas e com a mesma régua em que se mediu a AP e corresponde à distáncia em centímetros, entre a superficie do solo, contígua ao colo da planta, e a inserção da primeira espiga.

Rendimento de espigas ou peso de espigas por parcelas (RE): Devido ao fato das parcelas terem apresentado variaçōes em relação ao estande ideal de 25 plantas, as mensuraçōes do carater $R E$, que envolveram todas as plantas das unidades experimentais, sofreram, além das correçóes no teor de umidade dos grăos, ajustes para o referido estande .

A determinação do teor de umidade dos grãos foi feita em um aparelho "Steinlite". Os dados de RE foram entáo corrigidos para umidade 15,5\%, conforme a seguinte fórmula:

$$
\begin{aligned}
& \mathrm{PC}_{15.5}=\frac{\mathrm{PC}(1-u)}{0,845} \text { onde tem-se: } \\
& \mathrm{PC}_{15,5} \text { : peso de campo conigido para } 15,5 \% \text { de umidade } \\
& \mathrm{PC} \text { : peso de campo observado. } \\
& \mathrm{u}: \text { umidade observada em cada parcela. }
\end{aligned}
$$

A correção do estande foi feita através do método de covariáncia (STEEL \& TORRIE, 1960). A metodologia aqui usada baseia-se na realização de uma análise de variância relativa ao estande e de análise de covariância entre estande e peso das espigas, ambas tomando como base o delineamento de blocos casualizados. Obtem-se assim um coeficiente de regressão linear do peso de espigas em relação as variaçōes do estande (b), o qual 
é dado pelo $\mathrm{SP}_{e} / \mathrm{SQ}_{\mathrm{e}}$ onde $\mathrm{SP}_{\mathrm{e}}$ é a soma dos produtos residuais da análise de covariância e $S Q_{e}$ é a soma de quadrados residual da análise de variância do estande. A presente correção foi efetuada a nivel de totais de parcela segundo a fórmula:

$$
P c=P o-b(S-N) \text {, onde: }
$$

Pc: peso de campo corrigido para estande ideal de 25 plantas.

Po: peso de campo observado.

b: coeficiente de regressão linear do peso das espigas em relação às variações de estande com base em cada parcela de cada tratamento.

$\mathrm{N}$ : estande ideal.

S: estande observado.

Assim, as espigas colhidas de cada parcela eram despalhadas e pesadas. Os valores submetidos às correçōes de umidade e estande correspondem ao rendimento de espiga por parcela RE.

Amostras ao acaso, da primeira espiga, foram retiradas de quatro a cinco plantas competitivas da parcela. De cada espiga, devidamente identificada, em relação à planta que the deu origem, foram anotados os seguintes caracteres; peso de espiga (PE), peso de grãos (PG), comprimento de espiga (CE), diåmetro de espiga (DE), peso de 100 grãos (P100), número de grãos por fileira (GF), número de fileiras de grăos por espiga (NF) e diâmetro de sabugo (DS), descritos como se segue:

Peso de espigas (PE): Foi efetuado em espigas despalhadas. O PE, em gramas, foi obtido através de uma balança de marca Toledo, com capacidade máxima de $5 \mathrm{~kg}$ e sensibilidade a nivel de gramas.

Comprimento de espiga (CE): De cada uma das $k$ espigas retiradas dentro da parcela foi medido o CE em cm. Considerou-se como CE toda a extensão do sabugo, independente da presença ou não de grãos na base ou extremidade. A medida foi feita utilizando uma régua com cursor e escala milimétrica, especialmente confeccionada para as determina̧̧es de CE, DE e DS. 
Diâmetro de espiga (DE): Imediatamente após a determinaçăo do CE media-se o diâmetro da espiga, em cm, usando a régua já descrita. Considerando a forma cónica da maioria das espigas, e portanto o diâmetro diminuindo da base para a ponta da espiga, considerou-se o diametro mediano como o representativo de cada espiga.

Número de gros por fileiras (GF) e número de fileiras de gros por espiga (NF): Após medir o comprimento e diâmetro, contou-se o GF e NF para cada espiga.

Peso de grảos (PG): As espigas foram debulhadas e os grăos pesados na mesma balança e com a mesma unidade (g), usados na avaliaçăo do PE.

Peso de 100 grosos (P100): Foram tomados ao acaso 100 grãos de cada espiga, os quais foram pesados da mesma forma que se fez para PE.

Diâmetro de sabugo (DS): O DS foi avaliado usando a mesma régua, igual unidade e idênticos critérios da determinação do DE.

\section{2,2.2. Analise de laboratório}

Teor de óleo (TO): Das mesmas espigas, amostradas nas parcelas, conforme descrição no item anterior (3.2.2.1. Campo), obteve-se amostras de 20 grăos para a determinação do teor de óleo. Empregou-se o método de extração por solvente, usando n-hexano, um extrator tipo Soxhlet (TOSELLO, 1978 e BIANCO, 1984).

De forma semelhante ao item anterior, manteve-se a estrutura de látice, com as observaçס̋es dentro das parcelas.

\subsection{Análise estatistico-genética}

As análises estatísticas basicamente foram de dois tipos, análise de variância e análise de covariância.A execução destas análises foi feita da seguinte forma:inicialmente eram calculadas a média dos tratamentos e a variância dentro de cada tratamento de 
um dado látice e populaçăo (isto é, nos casos em que havia observaçóes dentro). A variância dentro posteriormente era indexada na análise do delineamento I (COMSTOCK \& ROBINSON, 1948). Em seguida procedia-se a análise de variância de cada látice individualmente, desta forma obtendo-se o valor do erro efetivo médio que era usado na análise do delineamento $\mathrm{I}$.

Após a análise individual de todos os experimentos (quatro por populaçóes) para uma característica em uma populaçăo, foi feito um agrupamento. O quadro de análise de variância agrupada do delineamento I tem como grau de liberdade e soma de quadrados a somatória dos graus de liberdade e somatória da soma dos quadrados das análises individuais, respectivamente. De uma forma semelhante foi feito o agrupamento para o cálculo da variância dentro.

No desdobramento dos tratamentos em machos e fêmeas/machos (delineamento 1), todas as vezes que havia somente uma fêmea por macho, impossibilitando assim o cálculo da variância de fémea/macho $(\hat{\sigma} \underset{\mathrm{f} / \mathrm{m}}{2}=0)$, o tratamento era eliminado, explicandose assim a năo correspondéncia do número total de tratamentos que constam dos quadros de análises com aqueles inicialmente avaliados em campo.

Foram feitas todas as análises de covariância possiveis dos caracteres RE e TO, ou seja, estudou-se a covariancia de cada um destes dois caracteres com todos os outros avaliados neste trabalho, perfazendo um total de 42 análises de covariância agrupadas para as duas populaçóes.

As análises de covariâncias foram executadas e agrupadas de maneira idéntica às análises de variância.

\section{Análises de variáncia}

Nas análises de variâncias feitas inicialmente para látice (COCHRAN \& COX, 1957), empregourse o seguinte modelo matemático.

$$
Y_{i j k l}=u+t_{i}+r_{k}+b_{j(k)}+e_{i j(k)}+d_{i(i j k)}
$$


onde:

$Y_{i j k l}=$ observaçăo relativa ao indlviduo $\mathrm{I}$, do tratamento $\mathrm{i}$, no bloco j da repetiçăo $\mathrm{k}$.

$\mathrm{u}=$ média geral.

$t_{i}=$ efeito do tratamento $i(i=1,2, \ldots 1)$.

$r_{k}=$ efeito da repetiçáo $k(k=1,2, \ldots K)$.

$b_{j(k)}=$ efeito do bloco j, dentro da repetiçáo $k(j=1,2, \ldots . J)$.

$e_{i j(k)}=$ erro experimental associado à parcela ij, dentro da repetiçáo $k$.

$d_{l(i j k)}=$ efeito concernente ao indlviduo $I$, da parcela $i j k(I=1,2, \ldots L)$.

Com exceção da média geral, todos os efeitos foram considerados como aleatórios tendo-se as seguintes esperanças matemáticas:

$E\left(t_{i}\right)=E\left(r_{k}\right)=E\left[b_{j(k)}\right]=E\left[e_{i j}(k)\right]=0$;

$E\left(t_{i}^{2}\right)=\sigma_{t}^{2} ; E\left(r_{k}^{2}=\sigma_{r}^{2} ; E\left[\sigma_{b j(k)}^{2}\right]=\sigma_{b^{\prime}}^{2} E\left[e^{2}{ }_{i j(k)}\right]=\sigma 2\right.$; sendo

$\sigma_{\mathrm{t}}^{2}=$ variância genética entre tratamentos.

$\sigma \underset{r}{2}=$ variância ambiental entre repetiçōes.

$\sigma{ }_{b}^{2}=$ variância ambiental entre blocos dentro de repetiçóes.

$\sigma^{2}=$ variancia do erro experimental entre parcelas, dentro de blocos.

A fonte de variaçăo dentro (caracteres avaliados planta a planta) foi estimada independente e posteriormente introduzida na análise.

As análises de variancias para todos os caracteres foram efetuadas com a média de parcela, à exceçáo do RE que foi feita com totais de parcelas.

Os tratamentos foram posteriormente desdobrados de acordo com o delineamento I (COMSTOCK \& ROBINSON, 1948). Nas análises de variâncias deste delineamento empregou-se o seguinte modelo matemático:

$$
\begin{aligned}
& Y_{i j k}=u+m_{i}+f_{j(i)}+r_{k}+e_{i j(k)} \text { onde: } \\
& u=\text { média geral } \\
& m_{i}=\text { efeito do macho } i(i=1,2, \ldots m) \\
& f_{j(i)}=\text { efeito da fêmea; no macho } i(j=1,2, \ldots f) . \\
& r_{k}=\text { efeito da repetiçáo } k(k=1,2 . . . k) \\
& \text { eij(k) = erro experimental associado à parcela do cruzamento do macho } i
\end{aligned}
$$

œm a fêmea j, dentro da repetiçao $k$. 
Da mesma forma já mencionada, com exceçâo da média geral, todos os efeitos foram considerados como aleatórios.

$\mathrm{Na}$ Tabela 1, encontram-se as esperanças matemáticas dos quadrados médios da análise de variáncia do delineamento $I$, acrescido da variância dentro ( $\sigma$ d). Este modelo de quadro de análise de variância foi usado para as análises individuais e agrupadas para todos os caracteres das duas populaçбes.

Partindo-se do pressuposto de que estimativas das variâncias individuais, dentro de parcelas, de maior magnitude possam estar associadas a erros experimentais (variapóes quanto a fertilidade do solo, incidéncias de pragas e doenças, enros de leitura em análise de laboratório, entre outros fatores), decidiu-se pela eliminaçáo de tais estimativas com vistas a uma avaliação mais precisa dos quadrados médios dentro de parcelas. A eliminação de algumas variâncias dentro, parte do principio de $S Q_{i j} / \sigma^{2}$ populacional, obtidos a partir de amostras aleatórias obedecem a distribuição de qui-quadrado $x^{2}$ (SNEDECOR \& COCHRAN, 1967 e ROHATGI, 1976).Deste modo, deliberou-se arbitrariamente excluir as estimativas com valores mais elevados, situados na porção final da cauda da distribuição de $\dot{x}^{2}$, correspondente a $1 \%$ da área total, conforme o proposto por SOARES FILHO (1987).

TABEAA 1 - Esperangas matemáticas dos quadrados médios das andlises de varianciasa segundo o detineamento $\mathrm{L}$ a nivel de media de parcelas

Fonte de Variaçáo

G.L. Q.M. $E\left(Q_{0} M_{*}\right)_{1}$

$E\left(Q . M_{0}\right)_{2}$

$\mathbf{F}$

$\begin{array}{llllll}\text { Repetiços } & - & - & & \\ \text { Machos } & g_{1} & Q_{1} & \sigma_{d}^{2} / K+\sigma_{e}^{2}+K_{1} \sigma_{\ell / m}^{2}+K_{2} \sigma_{m}^{2} & \sigma^{2}+K_{1} \sigma_{t / m}^{2}+K_{2} \sigma_{m}^{2} & Q_{1} / Q_{2} \\ \text { Fêmeas/machos } & g_{2} & Q_{2} & \sigma_{d}^{2} / K+\sigma_{e}^{2}+K_{1} \sigma_{\ell / m}^{2} & \sigma^{2}+K_{1} \sigma_{t / m}^{2} & Q_{2} / Q_{3} \\ \text { Emo efetivomødio } & g_{3} & Q_{3} & \sigma_{d}^{2 / K}+\sigma_{e}^{2} & \sigma^{2} & \\ \text { Dentro } & g_{4} & Q_{4} & \sigma_{d}^{2} & & \end{array}$

aAnálises considerando a presença $E\left(Q . M_{0}\right)_{1}$ e a auséncia $E(Q . M)_{2}$ da fonte de variaçáo dest tro. 
$\mathrm{Na}$ tabela das esperanças dos quadrados médios os coeficiente r(repetição) e f(número de fêmeas por machos) do delineamento i foram substituidos por $K_{1}$ e $K_{2}$, devido ao desbalanceamento ou diferentes números de fêmeas por machos.As estimativas dos valores de $\mathrm{K}_{1}$ e $\mathrm{K}_{2}$ foram obtidas segundo o procedimento VARCOMP DO SAS PC Versáo 60.3 para Nested design (SAS INSTITUTE, 1988), sendo $K=$ número de plantas avaliadas por parcela (peso de espigas $K=$ estande ideal; demais caracteres $K=K_{h}$ ou seja a média harmonica do número de plantas avaliadas por parcela).

\section{Da Tabela 1 serão estimados:}

$\hat{\sigma}_{m}^{2}=\left(Q_{1}-Q_{2}\right) / K_{2}:$ variáncia genética entre machos.

$\hat{\sigma}_{\hat{f} / \mathrm{m}}^{2}=\left(Q_{2}-Q_{3}\right) / K_{1}$ : variância entre fémeas dentro de machos.

$\hat{\sigma}_{e}^{2}=Q_{3}-Q_{4} / K:$ variância do erro ao nivel de parcelas.

$\hat{\sigma}_{d}^{2}=Q_{4}$ : variância fenotípica entre plantas dentro de parcelas.

A interpretação genética dos componentes de variáncia é a seguinte (COMSTOCK \& ROBINSON, 1948):

$$
\begin{aligned}
& \hat{\sigma}{ }_{m}^{2}=(1 / 4) \hat{\sigma}_{A}^{2} \\
& \hat{\sigma}_{f / m}^{2}=(1 / 4) \hat{\sigma}_{A}^{2}+1 / 4 \hat{\sigma}_{D}^{2} \text {. Assim, foram estimados os parâmetros gené }
\end{aligned}
$$

ticos e fenotípicos como se segue, (COMSTOCK \& ROBINSON, 1948 e HALLAUER \& MF RANDA FILHO, 1981):

$\hat{\sigma}_{\hat{A}}^{2}=4 \hat{\sigma}_{m}^{2}:$ variância genética aditiva.

$\hat{\sigma}_{D}^{2}=4\left(\hat{\sigma} \sum_{t / m}^{2}-\hat{\sigma}_{m}^{2}\right):$ variância genética dominante.

$\hat{\sigma}_{\mathrm{F}}^{2}=\hat{\sigma}_{\mathrm{m}}^{2}+\hat{\sigma} \hat{f}_{\mathrm{f} / \mathrm{m}}^{2}+\hat{\sigma}_{\mathrm{e}}^{2}+\hat{\sigma}_{\mathrm{d}}^{2}$ variancia fenotipica ao nivel de plantas.

$\hat{\sigma} \frac{2}{F}=Q_{1} / K_{2}$ variáncia fenotípica entre médias de progénies de meios

irmãos.Vale ressaltar que o valor médio obtido para um macho equivale ao de uma progénie de meio irmão, sendo este resultante da média das médias de progénies de imaāos germanos, provenientes do cruzamento daquele macho com j fêmeas. A mesma consideração deverá ser feita para os cálculos da herdabilidade ao nivel de médias de progénies de meios irmãos (h్,) do progresso esperado com a seleção de famílias de meios irmãos (Gs2) e nos estudos de co variåncia.

$$
\begin{gathered}
\hat{h}^{2}=\hat{\sigma}_{\hat{A}}^{2} / \hat{\sigma}_{F}^{2} \text { herdabilidade no sentido restrito ao nivel de plantas. } \\
\hat{h}_{X}^{2}=\hat{\sigma}_{\hat{p}}^{2} \frac{\hat{\sigma}_{2}^{2}}{F} \text { herdabilidade no sentido restrito, ao nivel de médias de } \\
\text { progénies de meios irmãos. }
\end{gathered}
$$


A partir destas estimativas foram obtidos os seguintes parâmetros:

a) Coeficiente de variação genética (em termos de progénies de meios irmãos).

$C V g \%=100 \times \quad \hat{\sigma}_{p} / u$

onde u: média

$\hat{\sigma}_{p}$ : raiz quadrada da variância de progênies de meios irmáos.

b) Coeficiente de variação experimental

CVe $\%=100 \times \sqrt{Q_{3} / u}$

c) İndice de variação genética

$\mathrm{b}=\mathrm{CVg} \% / \mathrm{CVe} \%$

Os progressos esperados foram obtidos conforme as expressões dadas por VENCOVSKY (1987).

d) $G s_{1}=i(1 / 2) \hat{\sigma}_{A}^{2 /} \hat{\sigma}_{F}$

Gs 1: progresso esperado com seleção massal em um só sexo.

i : diferencial de seleçáo estandardizado correspondente a uma intensidade de seleçăo de $10 \%(i=1,7555)$.

$\hat{\sigma}_{\mathrm{F}}:$ desvio padrão fenotipico entre plantas.

e) $G_{2}=i(1 / 4) \quad \hat{\sigma}_{\bar{A}}^{2} / \hat{\sigma}_{\bar{F}}$

Gs2 : progresso esperado com seleção entre famílias de meios irmãos, com sementes remanescentes.

P : diferencial de seleģáo estandardizada correspondente a uma intensidade de selegăo de $20 \%$ ( $i=1,3998)$.

$\hat{\sigma}_{\bar{F}}$ : desvio padrão fenotípico entre médias de famílias de meios irmãos.

\section{Análises de covariância}

As análises de covariância foram efetuadas a partir de análises de variância, mediante a aplicação do método apresentado por KEMPTHORNE (1966), o qual compreende, além da análise de cada caráter individualmente, uma análise de variáncia dos caracteres somados dois a dois. Os produtos médios entre caracteres resultam dos quadrados mé 
dios das análises de variâncias realizadas, segundo processo dado a seguir.

Quadrados médios(QM)

Machos

Femeas/machos

Erro efetivo médio
$\mathrm{QMm} m_{x} \mathrm{OMm} \mathrm{m}_{y} \mathrm{OMm}$

$\mathrm{QMt} / \mathrm{m}_{\mathrm{x}} \mathrm{QMt} / \mathrm{m}_{\mathrm{y}} \mathrm{QMt} / \mathrm{m}_{6}$

$\mathrm{QMe}_{\mathrm{x}} \mathrm{OM \theta _{y }} \mathrm{OMe}_{\mathrm{s}}$
Produtos médios (PM)

$$
\begin{aligned}
& P M m_{x, y}=1 / 2\left(Q M m_{s}-Q M m_{x}-Q M m_{y}\right) \\
& P M t / m_{x, y}+1 / 2\left(Q M t / m_{S}-Q M t / m_{x}-Q M t / m_{y}\right) \\
& P M e_{x, y}=1 / 2\left(Q M e_{s}-Q M e_{x}-Q M e_{y}\right)
\end{aligned}
$$

onde:

$x$ e $y=$ caracteres em estudo

$s=x+y$.

Com relação às combinações entre caracteres avaliados a partir de números diferentes de indíviduos por parcelas, como foi o caso entre o rendimento de espiga ( $n=$ estande ideal da parcela) e os demais caracteres ( $n \leq 5$ plantas), em razão das análises de covariância terem sido realizadas ao nivel de médias de parcelas, considerou-se para n o tamanho da amostra relativa ao caráter mensurado com base no maior número de indíviduos (RE), segundo demonstrado por GERALDI et alii (1978).

Em relação às demais combinaçōes, devido às variaçōes no tamanho das amostras obtidas dentro de parcelas, decorrentes de problemas de estande ; estabeleceu-se para $\mathrm{K}$ o valor correspondente à média harmónica dos números de plantas compreendidas por tais amostras relativamente a cada par de caracteres $(\mathrm{kh})$.

O agrupamento das análises de covariância foi feito de forma idêntica ao efetuado para análise de variância. Ou seja, analisava-se a covariância entre duas característi- 
cas em uma populaçăo, segundo o delineamento l, para cada látice e posteriormente fazia-se o agrupamento como descrito para a análise de variância (Tabela 2).

TABELA 2 - Esperangas matemáticas para os produtos médios das análises de covariáncias segundo o delineamento $\mathbf{L}$ no nivel de médias de parcelas.

Fonte de variaçăo

G.L

P.M.

$E(P . M$.

Machos

91

$P_{1}$

$\mathrm{COV}_{\mathrm{e}}+\mathrm{K}_{1} \mathrm{COV}_{\mathrm{f} / \mathrm{m}}+\mathrm{K}_{2} \mathrm{COV}_{\mathrm{m}}$

Fêmeas/machos

$g_{2}$

$\mathrm{P}_{2}$

$\mathrm{COV}_{\mathrm{e}}+\mathrm{K}_{1} \mathrm{COV}_{\mathrm{f} / \mathrm{m}}$

Erro efetivo médio

93

$\mathrm{P}_{3}$

$\mathrm{COV}_{\mathrm{e}}$

Os valores de $\mathrm{K}_{1}$ e $\mathrm{K}_{2}$ foram calculados de forma semelhante àquela da análise de variåncia, considerando o envolvimento de duas variáveis.

Da análise de covariância foram estimados os seguintes parâmetros:

CÔN $\mathrm{m}_{m}=\left(\mathrm{P}_{1}-\mathrm{P}_{2}\right) / \mathrm{K}_{2}$ : covariância genética entre os caracteres ao nivel de machos.

CÔ $V_{f / m}=\left(P_{2} \cdot P_{3}\right) / K_{1}$ : covariância genética entre caracteres ao nível de fêmeas dentro de machos.

CÔv $\mathrm{e}_{\mathrm{e}}=\mathrm{P}_{3}$ : covariância ambiental entre caracteres ao nivel de parcelas.

A interpretação genética dos componentes de covariância entre caracteres (COMSTOCK \& ROBINSON, 1948 e HALLAUER \& MIRANDA FILHO, 1981) foi a seguinte:

$\operatorname{côv}_{m}=1 / 4 \operatorname{CôV}_{A}$

CÔV $f / m=1 / 4$ CÔV $A+1 / 4$ CÔV . Assim serão estimados os seguintes parâmetros:

$\operatorname{CÔV}_{A}=4{ }_{C O ̂} V_{m}$ : covariância genética aditiva

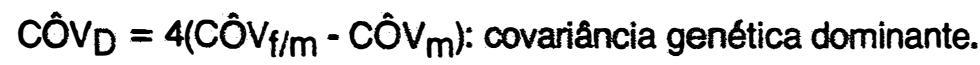

CÔ $V_{F}=P_{1} / K_{2}:$ covariância fenotípica entre médias de progênies de meios irmãos.

A partir destas estimativas, foram obtidas as correlaçóes genéticas e fenotlpicas de acordo com a metodologia relatada por FALCONER (1964) e KEMPTHORNE 
(1966), conforme apresentada a seguir:

a) $r_{A}(x, y)=\operatorname{Cô} V_{A(x, y)} \hat{\sigma}_{A x} \cdot \hat{\sigma}_{A y}$ : correlação genética aditiva entre pares de caracteres.

b) ${ }^{r} F(x, y)=\operatorname{CôV} F(x, y){ }^{\prime} \quad \hat{\sigma} \bar{F} x \cdot \hat{\sigma} \bar{F}_{y}:$ coeficiente de correlação fenotipica entre médios de famflias de meios imáos.

Conforme os procedimentos apresentados por FALCONER (1964), a expressão utilizada para estimar as respostas correlacionadas é a seguinte:

$R_{(y / x)}=i^{\prime} .1 / 4 \operatorname{CÔV}_{A(x, y)^{\prime}} \hat{\sigma}_{F x}$ : resposta correlacionada esperada no carater y quando a seleção é praticada em $x$, entre médias de familias de meios irmãos.

i': já definido em Gsa.

$\hat{\sigma}_{\overline{F X}}:$ desvio padrão fenotípico entre médias de familias de meios irmãos para o caráter $\mathrm{X}$.

\section{Distribuiçáo de frequéncias das médias dos caracteres}

Para todas as características estudadas, determinou-se a amplitude de variação (maior e menor valor avaliado), a média geral e o número de médias avaliadas. Em seguida determinou-se o intervalo de confiança segundo STEEL \& TORRIE (1960), da seguinte forma:

$$
\mathrm{IC}=\overline{\mathrm{x}}+\mathrm{t} \mathrm{S}_{\bar{x}}
$$

$\bar{X}$ : média geral observada para cada caráter.

$\mathrm{t}$ : valor tabelado de $\mathrm{t}$ a $5 \%$ de probabilidade, de acordo com os graus de liberdade.

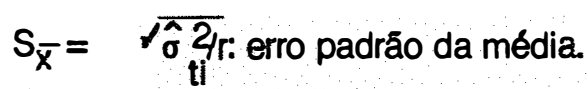

$\hat{\sigma}$ ti $^{2}$ estimativa da variância dos tratamentos na análise inicial dos látices.

$r=$ número de repetiçőes;

Finalmente traçou-se o polígono de frequência das médias de cada cará-

ter. 


\section{Precisáo das estimativas}

A precisão das estimativas dos componentes da variância $V\left(\hat{\sigma}_{\hat{A}}^{2}\right), V\left(\hat{\sigma} \frac{2}{D}\right)$, $V\left(\hat{\sigma} \underset{e}{2}\right.$ e V( $\left.\hat{\sigma}_{d}^{2}\right)$ foi calculada conforme a metodologia de VELLO \& VENCOVSKY (1974) e HALLAUER \& MIRANDA FILHO (1981) a partir dos quadrados médios e estimativas de variâncias através das seguintes relaçōes:

1) $v\left(\hat{\sigma}_{A}^{2}\right)=\frac{16 \times 2}{\left(K_{2}\right)^{2}}\left[\frac{Q_{1}}{\left(g_{1}+2\right)}+\frac{Q_{2}}{g_{2}+2}\right]$ : Variância da variância

2) $V \cdot\left(\hat{\sigma}_{D}^{2}\right)=\frac{16 \times 2}{\left(K_{1}\right)^{2}}\left[\frac{Q_{2}{ }^{2}}{g_{2}{ }^{2}}+\frac{Q_{3}{ }^{2}}{g_{3}+2}+\frac{1}{\left(K_{2} / K_{1}\right)^{2}}\left(\frac{Q_{1}{ }^{2}}{g_{1}+2}+\frac{Q_{2}{ }^{2}}{g_{2}{ }^{2}}\right)\right]$ :

Variância da Variância de dominância.

3) $v\left(\hat{\sigma}_{e}^{2}\right)=\frac{2}{k^{2}}\left[\frac{Q_{3}{ }^{2}}{g_{3}+2}+\frac{Q_{4}{ }^{2}}{g_{4}+2}\right]$ : $\begin{aligned} & \text { Variância da variância do } \\ & \text { erro efetivo médio. }\end{aligned}$

4) $v\left(\hat{\sigma}_{d}^{2}\right)=\frac{2 Q_{4}{ }^{2}}{\left(g_{4}+2\right)}$ : Variância da variância fenotipica entre 


\section{RESULTADOS E DISCUSSÃO}

\subsection{Médias populacionais}

Os caracteres peso de espigas (PE), peso de grăos (PG), peso de 100 grăos (P100), número de fileiras de grãos da espiga (NF), número e grãos por fileira (GF), diå metro da espiga (DE), diâmetro do sabugo (DS), juntamente com a prolificidade constituem-se nos principais componentes do rendimento de espiga (RE).

Os valores médios obtidos para PE, PG, DE, DS, AP e AE (Tabela 3) na populaçăo Piranão VD-2 foram superiores e mais precisos (menor intervalo de confiança), do que aqueles observados por SOARES FILHO (1987) para a mesma população. Comparando os resultados obtidos pelo mesmo autor para a população Piranão VF-1 B com aqueles da Piranão VF-1, tem-se que esta última população apresentou menores valores para $P E, P G, A P$ e $A E$, idéntico valor de DS e maior valor de DE em relação a Piranão VF-1 B. 
As alturas de planta e de espiga apresentadas pelas testemunhas $\mathrm{Ag}$ 352-B e DEK XL 540 foram, respectivamente, $159,38 \mathrm{~cm}$ e $86,11 \mathrm{~cm}$ e $168,61 \mathrm{~cm}$ e $86,00 \mathrm{~cm}$, enquanto os respectivos valores das populaçóes Piranão VD-2 e Piranão VF-1 foram $161,68 \mathrm{~cm}$ e $83,96 \mathrm{~cm}$ e $167,17 \mathrm{~cm}$ e $88,26 \mathrm{~cm}$.

Apesar dos resultados evidenciando uma maior AP e AE da população Piranão VD-2 em relaçăo à Piranão VF-1 (SOUZA Jr., 1981; SOUZA Jr., \& ZINSLY, 1981; PATERNIANI et alii, 1982 e CASTRO, 1983), os valores obtidos para estes caracteres (Tabela 3), embora próximos, mostram uma pequena superioridade na AP e AE da população Piranăo VF. 1. Esta alteração pode ter sido uma consequência do melhoramento para teor de óleo feita nestas populaçōes.

Trabalhando com a população ESAKQ-PB1, SANTOS (1985) observou valores inferiores de PE, PG, CE e DE, intermediários de GF e superiores de NF e DS em relaçăo as duas populaçóes usadas neste estudo.

Os valores médios de $32,36 \mathrm{~g}$ para peso de 100 grăos obtidos na população Piranão VD-2 foram superiores áqueles observados por ZIMBACK (1985) para milho opaco e idênticos aos valores da testemunha (ESALQ-VD) usada pelo autor. A população Piranão VF1 (com P100 igual a 29,05g) no entanto, apresentou valores próximos aos observados pelo mesmo autor para o composto braquítico VD opaco.

Nas Figuras 1-12 encontram-se as distribuiçoes de médias para os 12 caracteres avaliados. Com exceçăo de NF e DE da populaçăo Piranão VD-2, todas as demais curvas aproximam-se bastante de uma curva de distribuiçăo normal padrăo. 
Somente os caracteres RE, AP, AE e TO foram avaliados nas testemunhas Ag 352-B e DEK XL 540 e os valores médios obtidos foram comparados áqueles observados nas populaçס̋es estudadas.

Devido a importância atribuida ao caráter teor de óleo neste trabalho; sempre que possivel ele será discutido separadamente, de uma forma comparativa com os resultados obtidos na literatura. Os demais caracteres independente de sua maior ou menor importåncia serão considerados de forma global, sem se ater a detalhes de estimativas individuais.

\subsubsection{Médias populacionais para caracteres da planta}

Encontram-se na Tabela 3 os valores médios obtidos para os caracteres RE, PE, PG, P100, NF, GF, DE, CE, DS, AP, AE e os respectivos intervalos de confiança (IC) a $5 \%$ de probabilidade, referentes às duas populaçōes avaliadas.

O rendimento de espigas apresentado pela população Piranão VD-2 foi de $8,0151 \mathrm{~kg} / 5 \mathrm{~m}^{2}$, o que corresponde a 16,03 t/ha de espigas ou 13,16 t/ha de grăos (eliminando o peso de sabugo obtido para esta população). A população Piranão VF-1 apresentou rendimento de $6,7178 \mathrm{~kg} / 5 \mathrm{~m}^{2}$, correspondente a 13,44 t/ha de espigas ou a 10,89 t/ha de grãos. Comparando o RE das populaçóes com aqueles obtidos pelas testemunhas, observa-se que a população Piranão VD-2 apresentou rendimento médio ligeiramente superior aos 7,9993 $\mathrm{kg} / 5 \mathrm{~m}^{2}$ apresentado pelo Ag 352-B e pouco inferior aos 8,2033 kg/5m² da DEK XL 540, enquanto a população Piranão VF-1 apresentou rendimento inferior ao das duas testemunhas. Uma vez que os dois híbridos usados são materiais comerciais, verifica-se a boa performance das duas populaçరీes em relação ao rendimento.

Considerando o maior rendimento da população Piranão VD-2 em relação à população Piranão VF-1, era de se esperar que os componentes do RE também obedecessem esta ordem. Realmente, a populaçăo Piranão VD-2 apresentou maiores médias para PE, PG, P100, GF e DF do que a Piranão VF-1, no entanto esta última população teve um idêntico CE e uma maior média de NF em relação a Piranão VD-2. 
O fato de DE năo apresentar uma distribuiçăo mais próxima da normal pode ser devido talvez a unidade de mensuraçăo $(\mathrm{cm})$ emprégada em sua determinaçăo. A utilizạaáo de $\mathrm{mm}$ talvez fosse mais recomendável por permitir que a distribuição dos dados pudesse ser estabelecida com maior precisão, logrando assim um melhor ajuste em relaçăo à. arva normal. A descontinuidade ocorrida na cunva para o carater NF, talvez possa ser explicado pela distribuiçăo discreta e pela não ocorrência de valores ímpares de número de fileiras de gráos. Distribuiçáo irregular (que se afasta da normal) foi também obsenada para NF por SANTOS (1985) na populaçåo ESALQ PB1 e nos cruzamentos ESALQ PB1 × Cravo e ESALQ-PB1 $x$ Entrelaçado.

Para os caracteres CE e DS das duas populaçóes nota-se uma similaridade nas médias (Tabela 3), assim como nas suas curvas de distribuiçőes e amplitudes de variaçăo (Figuras 9-10).As maiores discrepâncias entre curvas de distribuiçס̄es e amplitude de variaçס̄es nas duas populaçס̄es ocorreu nos caracteres RE, PE, PG e AP (Figuras 2,3,4 e 11).

\subsection{Médias populacionais para teor de óleo}

Apesar do maior rendimento apresentado pela população Piranão VD-2, esta apresentou um teor de óleo médio inferior ao da Piranåo VF-1 (Tabela 3). Estudando o potencial genético para teor de óleo da semente,nestas mesmas populaçóes, BIANCO (1984) obteve valores de 4,62\% para a Piranão VD-2 e de 4,68\% para a Piranão VF-1, portanto inferiores àqueles obtidos neste trabalho. A diferença entre as médias do teor de bleo das duas populaçōes acentuou-se com a intensificaçăo do processo de melhoramento para óleo das populaçóes, haja vista o maior valor desta diferença obtido neste estudo em relaçáo àquele conseguido por BIANCO (1984).

O menor valor obtido para TO em milho foi de $1,2 \%$ na linhagem "Illinois Low Oil" após 87 geraçóes de seleçăo para baixo teor de óleo, enquanto o valor mais elevado foi de $21,3 \%$ observado na "Illinois High Oil" (ALEXANDER, 1988); valores em tomo de $17 \%$ de óleo, foram obtidos por MISEVIC \& ALEXANDER (1989) após 24 ciclos de seleção no sintético Alexho. Apesar destes extremos apresentados, os teores de óleo obtidos na maioria dos trabaIhos variam de 4-9\%, como pode ser constatado na Tabela 3 - Apéndice. A Piranăo 
VD-2 com 4,62\% de óleo (BIANCO, 1984) e a ESALQ VF-1 (embrião grande) com 6,21\% de óleo (ZANOTTO, 1986) foram respectivamente as populações com menor e maior teor de óleo entre as populações de alto óleo avaliadas no Departamento de Genética da ESALQ. Enquanto as testemunhas Ag-352-B e DEK XL 540 apresentaram respectivamente 4,63 e 4,48\% de óleo, o TO médio da população Piranão VD-2 foi de 4,79\% e da Piranão VF-1 foi de 5,06\%. Apesar de ter rendimentos de espigas comparáveis aos híbridos comerciais, as populações avaliadas apresentam teor de óleo bem superior.

Embora seja possivel aumentar o teor de óleo de qualquer população de milho, o procedimento às vezes não é economicamente viável, uma vez que altas concentra̧ões em óleo invariavelmente estão associadas a baixos rendimentos de espiga.

A Figura 1 mostra a curva de distribuição das médias para o teor de óleo nas populações Piranão VD-2 e Piranão VF-1. Por esta figura, constata-se que as duas popula̧̧ões apresentaram distribuição de médias e amplitudes de variação semelhantes, embora a sua média geral tenha sido diierente.

\section{Consideragúes sobre o Delinoamento I}

O delineamento I subentende-se como delineamento estatístico de efeitos aleatórios. Além de fornecer estimativas de variância aditiva e de variância de dominância, ele permite ainda estimar a capacidade geral de combinação dos machos. Para que o modelo básico do delineamento seja atendido são necessárias as condições: herança diplóide, ausência de epistasia e equilíbrio de Hardy-Weinberg e de ligação (COMSTOCK \& ROBINSON, 1952). Este delineamento apresenta dois inconvenientes: 1) alta frequência de estimativas de variâncias negativas, principalmente variância de dominåncia; 2) imprecisão na estimativa da variância de dominância, uma vez que o erro padrão associado a este parâmetro é sempre grande devido à função complexa usada no seu cálculo (COMSTOCK \& ROBINSON, 1952; HALLAUER \& MIRANDA FILHO, 1981; BRIDGES \& KNAPP, 1987).

O uso do delineamento I tem levado à obtenção de estimativas de variância de dominância negativas para todos os caracteres da planta (LINDSEY et alii, 1962; GOODMAN, 1965; WILLIAMS et alii, 1965; EBERHART et alii, 1966; HALLAUER \& WRIGHT, 
1967). A ocorrência de estimativas de variâncias aditivas negativas é bem menor e tem sido verificada somente para alguns caracteres (WILLIAMS et alii, 1965; MARQUEZ-SANCHEZ \& HALLAUER, 1970; BRIDGES \& KNAPP, 1987).

As principais causas atribuldas à obtenção de variâncias negativas são: 1) uso inadequado do delineamento experimental; 2) inadequação do sistema de amostragem; 3) ordenação dos cruzamentos; 4) reduzido número de fêmeas por machos em caracteres com baixa herdabilidade (LINDSEY et alii; 1962; MARQUEZ-SANCHEZ \& HALLAUER, 1970; HALLAUER \& MIRANDA FILHO, 1981 e BRIDGES \& KNAPP, 1987).

Apesar de todos estes inconvenientes o delineamento I é usado com mais frequência do que o delineamento II de Comstock e Robinson, principalmente devido a facilidade de obtenção dos acasalamentos.

\subsection{Potencial das populaçōes para o melhoramento}

$\mathrm{Na}$ análise agrupada, foi eliminado um látice $10 \times 10$ da população Piranão VD-2, por apresentar valores de CVe\% não compativeis com os demais látices, bem como por fornecer estimativas de variâncias negativas para a maioria dos caracteres avaliados. Assim esta análise foi efetuada atendendo a observância da regra de Box (GOMES, 1976) a qual estabelece que em tais situações o valor do quadrado médio residual de maior magnitude nunca deve exceder ao daquele de menor tamanho de 3 a 4 vezes.

Nas Tabelas 4 e 5, onde são apresentados os valores de significância dos quadrados médios de 12 caracteres da planta das populações Piranão VD-2 e Piranão VF1, observa-se que o $\mathrm{F}$ para machos foi significativo somente para os caracteres TO, P100 e CE, enquanto a significância de $F$ para fêmeas/machos ocorreu para os caracteres $T O, N F, D E, C E$, DS, AP e AE da população Piranão VD-2. Considerando que o F para lêmeas/machos é o resultado da razão $Q M_{f} / m / Q M_{e}$ e que o $F$ para machos resulta da razão $Q M_{m} / Q M_{f} / m$ conclui-se que os valores de $\mathrm{QM}_{\mathrm{m}}$ são baixos em relação aos demais quadrados médios, o que resultará na obtenção de baixas variâncias aditivas.

Uma vez que o $\mathrm{F}$ para machos do caráter $\mathrm{RE}$ não foi significativo espera- 
va-se que um ou mais carácteres componentes do RE assim também o fossem (Tabela 4), isto, no entanto, nåo explica os valores de F nåo significativos obtidos para AP e AE.

Ao contrário do que ocorreu na população Piranão VD-2, na Piranão VF-1 todos os caracteres, com exceçăo da AP, GF e CE apresentaram F de machos significativo e o F de fêmeas/machos também significativo para todos caracteres, exceto AE (Tabela 5).

Apesar do RE ter sido avaliado em toda parcela (estande ideal) e seus componentes em amostras dentro de parcelas ( $n \leq 5$ plantas) houve uma total coincidéncia entre o rendimento de espiga e seus principais componentes (PE e PG) quanto a significáncia de F.

A população Piranão VD-2, com F de machos não significativos para a maioria dos caracteres, apresentou $\mathrm{F}$ de machos para teor de bleo significativo a 1\% de probabilidade, enquanto a Piranão VF-1, que teve F de machos altamente significativo ( $1 \%$ de probabilidade) para RE e seus componentes, teve $F$ de machos para teor de óleo somente significativo a 5\% de probabilidade. O estágio do melhoramento do TO e do RE das duas populaçóes talvez explique os valores médios alcançados por estes caracteres e seu nivel de significância de F.

\subsubsection{Coeficientes de variaçáo experimental (CVe\%), genética (CVg\%) e Indice de varia căo $(b=C V g \% / C V e \%)$ para caracteres da planta}

Conforme mencionado anteriormente, o caráter RE está estreitamente relacionado aos caracteres PE e PG, que são seus principais componentes. Também já foi dito que as amostras para RE foram tomadas em toda parcela que, com a correção do estande tinha 25 plantas (estande ideal), enquanto PE e PG foram avaliados em amostras de aproximadamente cinco plantas ( $n \leq 5)$. A amostragem de toda parcela associada à correção do estande na avaliaçåo do RE resultou na obtenção de CVe\% para este carater inferior áqueles obtidos para PE e PG.

O CVe\% obtido para um caráter na população Piranão VD-2 foi praticamente o mesmo obtido para este caráter na população Piranão VF-1 (Tabelas 4 e 5). Comparando 
estes valores de CVe\% com as médias obtidas na literatura para os mesmos parâmetros e caracteres, tem-se que o RE e CE tiveram CVe\% inferiores, NF, GF, DE e DS apresentaram valores idênticos, enquanto $P 100, A P$ e $A E$ assumiram valores superiores aqueles médios que constam da Tabela 13 - Apêndice.

Apesar dos CVe\%'s apresentados pela AP e AE nas duas populações estudadas serem superiores à. média da Tabela 13 - Apêndice, eles não ultrapassaram o valor superior da amplitude de variação observada para este parâmetro nos diversos trabalhos. No entanto, este limite foi ultrapassado em $29 \%$ pelo CVe\% do caráter P100.

À semelhança do que foi determinado no presente trabalho, cabe mencionar RISSI (1980) que chamou a atenção para o fato de que habitualmente o caráter $\mathrm{AE}$ apresenta $\mathrm{CVe} \%$ superior a $\mathrm{AP}$ tanto em materiais normais quanto naqueles braquíticos, não obstante as mensurações destes caracteres provirem de um mesmo conjunto de plantas.

A análise comparativa dos valores dos coeficientes de variação experimental para caracteres da planta das duas populações empregadas neste estudo, com as correspondentes médias de $\mathrm{CVe} \%$, obtidas para os mesmos caracteres em outras populações (Tabela 13 - Apêndice), leva a concluir que, de um modo geral, os experimentos tiveram uma precisão de média a alta.

Tendo-se em vista que os coeficientes de variação experimental normalmente diferem entre os distintos caracteres e condições experimentais e considerando $o$ fato de que o coeficiente de variação genética tem sua magnitude influenciada pela média do caráter ou caracteres que se esteja considerando, Vencovsky (1975), citado por GERALDI (1977), e RAMALHO (1977), sugere que a comparação da variabilidade genética de um dado caráter entre diferentes populações, bem como entre diversos caracteres ao nivel de uma mesma população ou conjunto de populações, seja efetuado através do índice de variação ou coeficiente $b$, que dá a proporção da variância genética entre progênies em relação ao erro residual, além de eliminar a influência da média populacional nas comparações a serem realizadas. Conforme mencionado em material e métodos, considerou-se para o cálculo de $\mathrm{CVg} \%$ a variância de famílias de meios irmãos, ou seja, considerou-se $1 / 4$ da variancia aditiva. 
Para os caracteres GF e DE da população Piranão VD-2 não foi possível estimar os parâmetros $\mathrm{CVg} \%$ e b, devido aos valores negativos obtidos para variância de machos. Os demais caracteres da população Piranão VD-2, com exceção de CE e AE, também apresentaram valores $\mathrm{CVg} \%$ e b inferiores aos da Piranão VF-1. O coeficiente de variação genética do CE e o índice de variação do CE e AP da população Piranão VD-2 foram superiores àqueles parâmetros dos mesmos caracteres da Piranảo VF-1.

Em relação ao coeficiente de variação genética, SAMPAIO (1986) relacionou um total de 41 estimativas relativas ao rendimento de grãos de diferentes variedades de milho, encontrando-se as mesmas compreendidas entre os limites de 3,4 e 21,0\%, com uma média de 8,0\% Estes valores em sua maioria inferiores a 10,0\%, ao serem confrontados com os da Tabela 4 e 5 evidenciam o baixo CVg\% para RE da população Piranão VD-2, enquanto a população VF-1 apresentou valor médio para este parâmetro.

Em levantamento bibliográfico apresentado por SAMPAIO (1986) envolvendo 38 estimativas referentes ao rendimento de grãos de várias populações de milho, os valores dos indices de variação estiveram entre os limites de 0,22 a 0,92 com uma média de 0,49. Os resultados obtidos para $b$, nas duas populações enquadram-se neste intervalo. $O$ valor do Indice de variação da população Piranão VF-1 é praticamente igual a média obtida pelo autor.

De uma forma geral, todos os caracteres da população Piranão VD-2 apresentaram valores $b$ de médio a baixos, enquanto os índices de variação da população Piranão VF-1 assumiram valores médios em relação aos observados na literatura.

\subsection{Coeficientes de variação experimental (CVe\%), genética (CVg\%) e indice de varia ção $(b=C V g \% / C V e \%)$ para teor de óleo}

Os valores de $5,97 \%$ e $5,40 \%$ obtidos para os coeficientes de variação experimental, respectivamente para as populações Piranão VD-2 e Piranão VF-1, foram idêntiœs àqueles obtidos por BIANCO (1984) para as mesmas populações. Em média, os coeficientes de variação experimental para teor de óleo obtidos em outros trabalhos foram superiores aos calculados para as duas populaçoes (MORENO_GONZALES et alii, 1975; MI- 
RANDA et alii, 1976; TOSELLO \& GERALDI, 1980a; ZIMBACK, 1985 e ZANOTTO, 1986), embora KINOSHITA \& PATERNIANI (1973) tenham obtido CVe\% inferior aos observados neste estudo.

A população Piranão VD-2 apresentou CVg\% duas vezes maior do que aquele apresentado pela Piranão VF-1. Uma vez que as duas possuem CVe\% próximos, dai o valor $b$ da Piranão VD-2 ser superior ao da Piranão VF-1. A média de índice de variação obtida de oito populaçōes da Tabela 3 - Apêndice foi superior ao valor $b$ da população Piranão VF-1 e inferior ao da Piranåo VD-2 (Tabelas 4 e 5).

O coeficiente de variação experimental e o indice de variação das duas populaçōes comparados aos resultados obtidos por diferentes autores permite a afirmativa de que os CVe\% para TO no presente estudo foram de médios a baixos e os valores de b de médios a altos.

\subsubsection{Variâncias genéticas ambientais e fenotipicas para caracteres da planta}

Entre as 48 estimativas de variâncias aditivas $\left(\hat{\sigma}_{\hat{A}}^{2}\right)$ e dominantes $\left(\hat{\sigma}_{\mathrm{D}}^{2}\right)$ das populações Piranão VD-2 e Piranão VF-1 obtidas para 12 caracteres ocorreram sete com valores negativos. Os caracteres GF e DE da população Piranão VD-2 foram os únicos casos de $\hat{\sigma}_{A}^{2}$ negativa. Estimativas de $\hat{\sigma}_{D}^{2}$ negativas foram obtidas para os caracteres $P 100, G F$ das duas populaçōes e AE da população Piranão VF-1 (Tabelas 6 e 7).

Várias são as hipóteses que poderiam explicar as estimativas negativas. A primeira e mais simples seria a de que os verdadeiros valores destas estimativas seriam algo próximo de zero e portanto, possivel de ocorrer valores negativos, haja vista os pequenos valores das variâncias em relação aos seus próprios erros padrão. Em segundo lugar, deve-se considerar que uma das características do delineamento I é a frequente ocorrência de variância genética negativa (BRIDGES \& KNAPP, 1987), fato que se acentua pela ordenação dos cruzamentos (LINDSEY et alii, 1962; MARQUEZ SANCHEZ \& HALLAUER, 1970). A última hipotese é a de que o número de fêmeas por machos usada no delineamento I foi muito baixo. Assim, para os caracteres P100, GF, DE e AE que apresentaram variâncias negativas, são sugeridos respectivamente seis, seis, quatro e seis fêmeas por machos (MARQUEZ SANCHEZ \& HAL- 
LAUER, 1970), ao invés de trés como empregado neste estudo.

Considerando os baixos valores da variância aditiva do caráter diâmetro da espiga obtidos em diferentes populações (Tabela 7 - Apendice), a primeira hipótese é a mais adequada para explicar o valor negativo ocorrido. No caso do número de grãos por fileira a primeira situação não se aplica bem, uma vez que as estimativas dos $\hat{\sigma}_{\hat{A}}^{2}$ deste caráter são bem maiores que a do DE (Tabela 10 - Apéndice).Devido a ocorréncia sistemática de estimativas de $\hat{\sigma}_{D}^{2}$ negativas para $\mathrm{P} 100$ e dos baixos valores das estimativas da $\hat{\sigma} 2$ quando positivas (EL ROUBY \& PENNY, 1967; MILLER et alii, 1981), pode se afirmar que o verdadeiro valor da variância de dominância deste caráter é muito baixo (próximo de zero), portanto os genes de ação dominante não são importantes para o peso de 100 grăos. Variâncias de domináncia negativas, portanto consideradas iguais a zero, foram obtidas para o caráter GF nas duas populaçőes avaliadas e por VARGAS et alii (1982) na população ZAC-58. Considerando a existéncia generalizada de variância de dominância diferente de zero para altura de espiga (HALLAUER \& MIRANDA FILHO, 1981; BENITEZ TORRES, 1986), a ocorréncia pouco frequente de variâncias dominantes negativas para este mesmo caráter (MARQUEZ-SANCHEZ \& HALLAUER, 1970 e VARGAS et alii, 1982) e levando-se em conta ainda que somente a população Piranão VF-1 apresentou $\hat{\sigma}_{D}^{2}$ negativa, as tres hipóteses anteriormente levantadas poderiam explicar este fato. Tendo em vista que o caráter $A P$, estreitamente relacionado a $A E$, apresentou $\hat{\sigma} 2 \frac{2}{D}$ que náo difere de zero, é lógico pensar que o verdadeiro valor da $\hat{o}_{D}^{2}$ de AE da população Piranão VF-1 seja zero.

Apesar da involuntária sistematização dos cruzamentos e da impossibilidade de obtenção de maior número de fêmeas por machos a oconéncia de variâncias negativas foi baixa.

Independente do caráter e dos valores obtidos para $\hat{\sigma}_{A}^{2}$ e $\hat{\sigma}_{D}^{2}$, na maioria dos trabalhos levantados, a variância aditiva foi sempre maior que a variancia de domináncia (MOLL \& ROBINSON, 1967; MARQUEZ-SANCHEZ \& HALLAUER, 1970; HALLAUER \& MIRANDA FILHO, 1981; VARGAS et alii, 1982; VALOIS \& MIRANDA FILHO, 1984 e BENITEZ TORRES, 1986). 
A auséncia do cálculo da $\hat{o}_{d}^{2}$ para o caráter RE impediu a estimativa da variância fenotípica entre plantas e consequentemente da herdabilidade no sentido restrito a nivel de plantas $\left(h^{2}\right)$ e do progresso esperado na seleção massal. No intuito de contornar o problema, GARDNER (1961), apoiandose em conhecimentos de natureza empírica, sugeriu a possibilidade do emprego da relaçáo $\hat{\sigma}_{d}^{2}=10 \hat{\sigma} \underset{e}{2}$ nos casos específicos de rendimento de grãos, em que a fonte de variação entre plantas dentro de progénies fosse desconhecida. No entanto, QUEIROZ (1969) indicou como mais recomendável a relação $\hat{\sigma}_{d}^{2}=5 \hat{\sigma}{ }_{e}^{2} \mathrm{em}$ se tratando de pesquisas conduzidas sob condiçס̋es experimentais peculiares ás condiçőes do Departamento de Genética IESALQ-USP. Considerando que foram obtidas as variâncias fenotípicas entre plantas dentro de parcelas para PE e PG e que estes caracteres, juntamente com o número de espigas, são os principais componentes do RE, assim a herdabilidade a nivel de plantas estimada para PE e PG dará uma idéia da $h^{2}$ que se obteria para RE.

Estimativas com maior precisão são aquelas (em tese) em que os caracteres, a priori, são reconhecidos por sua alta herdabilidade. Caracteres como RE e seus componentes principais, como o PE e PG, deveriam ser avaliados com maior número de plantas possiveis (AGUILAR MORAN, 1984 e SOARES FILHO, 1987), evitando-se casos de falta de precisão como o ocorrido para a variância aditiva do peso de espigas na população Piranão VD-2 (Tabela 6). Via de regra a precisão das estimativas de variâncias genéticas é relativamente baixa (VELLO \& VENCOVSKY, 1974), exceção à variância fenotípica entre plantas dentro de progénies ( $\hat{\sigma}_{\mathrm{d}}^{2}$ ) onde a alta precisão de suas estimativas deve-se primeiro ao número elevado de graus de liberdade, e em segundo lugar, é que as mesmas provieram de quadrados médios únicos calculados independentemente das análises de variâncias, ao contrário de outras estimativas de variâncias primárias ( $\hat{\sigma}_{\mathrm{m}}^{2}, \hat{\sigma} \sum_{\mathrm{f} / \mathrm{m}}^{2}$ e $\hat{\sigma} \mathrm{e}^{2}$, que procederam de equaçōes algébricas envolvendo um maior número de quadrados médios, estando sujeitos consequentemente a erros mais expressivos. Além disso, a eliminação dos quadrados médios, obtdos dentro da parcela, que se mostraram relativamente elevados e portanto poderiam estar associados a erros experimentais, contribuiu para a maior precisão da $\hat{\sigma}_{\mathrm{d}^{*}}^{2}$

Os valores de variância aditiva do rendimento de espiga das populaçбes avaliadas, quando transformados para as mesmas unidades usadas na Tabela 4 - Apéndice para rendimentos de grăos, resultam em 454,83 (g/pta) ${ }^{2}$ e 1063,36 $(\mathrm{g} / \mathrm{pta})^{2}$ respectivamente para 
as populaçóes Piranão VD-2 e Piranão VF-1. Variâncias aditivas para rendimento de grãos de 423 (g/pta) $)^{2}$ para a populaçáo Piranão VD-2B e de 879 (g/pta) ${ }^{2}$ para o Piranáo VF-1B foram obtidas por SOARES FILHO (1987). A média de 99 estimativas de variâncias aditivas para rendimento de grãos, calculada por HALLAUER \& MIRANDA FILHO (1981) foi de 469,1 (g/planta)². VENCOVSKY et alii (1988) obtiveram uma variância aditiva média de 309 (g/pta) ${ }^{2}$ para 58 estimativas. Face ao exposto e considerando que o rendimento em espiga apresenta variáncia aditiva um pouco maior que o rendimento de grãos, conclui-se que os valores obtidos para $\hat{\sigma} 2_{A}$ do RE da população Piranão VD-2 é um valor médio e da Piranão VF-1 é considerado alto.

A variância de dominância para RE da população Piranão VD-2 não diferiu de zero, enquanto a população Piranão VF-1 apresentou $\hat{\sigma}_{\mathrm{D}}^{2}$ diferente de zero (Tabelas 6 e 7). A forma complexa de estimar o erro associado a estimativa de ô 2 normalmente leva a obtenção de erros padrões elevados e consequentemente a variâncias de dominâncias que não diferem de zero; no entanto, as 99 estimativas levantadas por HALLAUER \& MIRANDA FILHO (1981) apresentaram em média 286,8 (g/planta $)^{2}$ para variáncia de domináncia e 210,0 (g/planta) ${ }^{2}$ para o desvio padrão.

Com exceção da $\hat{\sigma}_{A}^{2}$ do TO, P100 e CE, todas as estimativas de variâncias aditivas dos caracteres da planta da população Piranão VF-1 foram superiores àquelas da populaçáo Piranão VD-2. As duas populaçóes apresentaram valores idênticos para $\hat{\sigma}_{\hat{A}}^{2}$ de P100, enquanto as variâncias aditivas estimadas para CE e TO da população Piranăo VD-2 foram superiores ao da Piranão VF-1.

Dos 12 caracteres avaliados, sete da populaçăo Piranáo VD-2 (TO, NF, CE, DS, DE, AP e AE) e cinco da Piranão VF-1 (TO, NF, CE, DS e RE) apresentaram estimativas de variâncias de dominância diferentes de zero (Tabela 6 e 7). Como pode ser observado para os caracteres TO, NF, CE, DS a $\hat{\sigma} 2$ significativa ocorreu nas duas populaçōes, enquanto que para DE, AP e AE este fato só se verificou na população Piranão VD-2.

\subsection{Vanáncias geneticas ambientais e fenotipicas para teor de óleo}

Quando comparadas as duas populaçbes avaliadas em termos de $\hat{\sigma} \underset{A}{2}$ 
nota-se que a Piranão VD-2 apresentou uma estimativa maior para este parâmetro em relaçăo à população Piranão VF-1 (Tabelas 6 e 7). Os valores estimados para as duas populaçőes, no entanto, foram inferioes à média das 17 estimativas das variâncias aditivas apresentadas na Tabela 3 - Apêndice.

A população Piranão VF-1 com menor variância aditiva, apresentou variância de dominancia superior à Piranão VD-2 mas em ambas as populaçóes foi detectada ô 2 diferente de zero, fato este também verificado por SPRAGUE \& BRIMHALL (1949), MORENO-GONZALEZ et alii, (1975) e DUDLEY (1977). Conclui-se, assim, que os genes de asão dominantes são importantes no estabelecimento do teor de óleo das populaçōes Piranão VD-2 e Piranão VF-1. Uma vez que foi observado efeito de heterose para TO (DUDLEY, 1977), espera-se que os hibridos obtidos destas populaçōes apresentem teores de óleo bem superiores às linhagens que lhes deram origem.

O baixo valor estimado para a variância aditiva inferior ao valor da estimativa de variância de dominância do TO, observado na população Piranão VF-1, pode ter sido causado pelos desvios, inerentes às estimativas de $\hat{\sigma} \hat{D}$ (COMSTOCK \& ROBINSON, 1952) e ou uma pequena redução na $\hat{\sigma}_{A}^{2}$ provocada pela sua exploração no processo seletivo ou mesmo as duas causas associadas. Mas isto náo vai de encontro à maioria dos rabalhos de herança quantitativa do teor de óleo em milho, os quais levaram à conclusão de que a variância aditiva é o principal fator que afeta o controle deste caráter (SPRAGUE \& BRIMHALL, 1949; EL ROUBY \& PENNY, 1967; LENG, 1974; DUDLEY et alii 1977; MILLER et alii, 1981).

Independente do caráter, o número mínimo de fêmeas por machos, sugerido para o delineamento l, é quatro (MARQUEZ-SANCHEZ \& HALLAUER, 1970). Embora não haja na literatura informaç̧es sobre o número mais adequado de fêmeas/machos para o caráter TO, é lógico supor que o número médio de 3,1 femeas por machos usada neste experimento tenha sido baixo, o que poderia provocar distorçóes nas estimativas dos parâmetros. Inclusive, este fato poderia explicar a obtenção de $\hat{\sigma}_{D}^{2}$ superior a $\hat{\sigma}_{A}^{2}$ como a que ocorreu na população Piranão VF-1. Uma vez que os valores de $\hat{\sigma}_{D}^{2}$ das duas populaçð̋es são semelhantes e que a população Piranão VF-1 apresenta maior média de TO, e por isto supbese mais melhorada para este caráter, a possibilidade de pequena reduçăo da variância aditiva também náo pode ser descartada. 
A variância fenotípica dentro de progênie foi aproximadamente 10 vezes maior que a variância do erro e portanto semelhante a razão entre estas variâncias sugerida por GARDNER (1961) para o rendimento de grãos. A variância de machos foi inferior a variância fenotípica entre plantas dentro de progénies; resultados semelhantes foram obtidos por MlRANDA et alii (1976), ZIMBACK (1985) e ZANOTTO (1986) na relação entre variância de progênie e variância fenotípica entre plantas dentro de parcela.

As duas populaçóes apresentaram suficiente variabilidade genética para obtenção de progressos significativos em programa de melhoramento para o teor de óleo.

\subsubsection{Coeficientes de herdabilidade para caracteres da planta}

Com exceção do TO e CE, todos os caracteres da população Piranão VF1 apresentaram herdabilidade superior aos da população Piranão VD-2 (Tabela 6 e 7). Somente os caracteres TO e P100 da população Piranão VD-2 apresentaram herdabilidade média a alta. Todos os outros caracteres desta população tiveram baixa $h^{2}$. Na população Piranão VF-1 ao contrário, somente GF, CE e AP tiveram baixa herdabilidade, todos os outros apresentaram valores de $\mathrm{h}^{2}$ médios a altos.

Em caracteres mais influenciados pelo ambiente, a herdabilidade a nivel de médias tende a ser superior àquela determinada a nivel de plantas. Assim sendo, a indicaçâo deste ou daquele processo seletivo relativamente ao melhoramento de um dado caracter deverá basear-se preferivelmente em sua herdabilidade ao nivel de planta, visto que esta reflete com maior fidelidade o comportamento frente às variaçóes ambientais.

Os valores de herdabilidade ao nivel de plantas para PE $(3,73 \%)$ e PG (5,61\%) da população Piranão VD-2, apesar de baixos em relação aos dados da Tabela 4 Apêndice, foram compativeis com os valores observados por BIGOTO (1988) nas populaçóes ESALQ PB-1-II e ESALQ PB-1-IV. As herdabilidades de 13,57\% para PE e 13,63\% para PG da população Piranáo VF-1 encontram-se em torno da média $(11,00 \%)$ de 58 estimativas obtidas para rendimento de grãos (VENCOVSKY et alii, 1988). 
Considerando que a herdabilidade a nivel de planta foi proporcional àquela obtida a nível de médias de parcelas e que os valorés de herdabilidade a nivel de médias de parcelas para caráter RE foi superior aos obtidos para PE e PG, os valores de $h^{2}$ para o RE caso fossem estimados, seriam médios a altos em relação aos da Tabela 4 - Apendice.

Os valores de $h^{2}$ obtidos para AP e AE foram inferiores a todas as estimativas da Tabela 5 - Apéndice, sendo compativeis apenas com os valores observados por ZANOTTO (1986) para a população ESALQ VF-1.

A alta herdabilidade observada para o caráter $\mathrm{P} 100$ nas populaçōes Piranão VD-2 e Piranão VF-1 foi semelhante àquelas observadas por diversos autores (Tabela 9 Apéndice). No entanto, a herdabilidade elevada para os caracteres NF e GF detectada na literatura (Tabela 10 - Apéndice) não foi verificada nas populaçóes avaliadas.

O caráter DE da população Piranão VF-1 apresentou uma estimativa de herdabilidade de 49,54\%, portanto muito semelhante à maioria dos valores de $h^{2}$ levantados na Tabela 7 - Apêndice. A ocorrência de variância aditiva negativa para este caráter e para a GF na população Piranão VD-2 impediu o cálculo de sua herdabilidade.

Conforme pode ser observado nas Tabelas 6 e 7, os caracteres GF, CE e AP apresentaram uma herdabilidade muito baixa nas duas populaçbees avaliadas. Para o caráter CE, os valores obtidos de herdabilidade tanto na populaçăo Piranão VD-2 quanto na população Piranão VF-1 foram inferiores a todas as estimativas de parâmetro da Tabela 6 - Apêndice.

Enquanto a população Piranão VF-1 apresentou valor de herdabilidade média para DS compativel com os da Tabela 8 - Apêndice, a herdabilidade do DS estimada para a população Piranão VD-2 foi inferior a todos os valores daquela tabela.

Como pode ser verificado, muitos caracteres como AP, AE, NF e GF de alta herdabilidade apresentaram valores baixos de $h^{2}$. As possiveis causas para que isto tenha ocorrido são: 1) estimativas de variâncias imprecisas e 2) alterações dos parâmetros populacio- 
nais resultantes do processo de seleção para óleo efetuado nas populaçbees.

\subsubsection{Coeficientes de herdabilidade para teor de óleo}

Os valores de herdabilidade obtidos nas duas populaçbes(Tabelas 6 e 7), foram intermediários aos extremos obsenados para o caráter em outras pesquisas. Enquanto a população Piranão VD-2 apresentou herdabilidade a nivel de plantas semelhantes à da média (53,25\%) das estimativas deste parâmetro em várias populaçőes (Tabela 3 - Apéndice) a Piranão VF-1 teve um valor bem inferior a esta, embora superior àquelas observadas por ZIMBACK (1985) em milho braquítico dentado opaco e por ZANOTTO (1986) na população ESALQ VF-1. Em termos de herdabilidade média, ambas populaçbes apresentaram valores superiores ao valor médio de 16,22\% obtido para as cinco populaçőes da Tabela 3 - Apéndice.

A herdabilidade média a alta para o TO, explicada pelo fato de que este caráter, embora quantitativo, seja controlado por um número relativamente pequeno de genes (SPRAGUE \& BRIMHALL, 1949 e DUDLEY, 1977), indica que esquemas simples de seleção devem conduzir a bons resultados no melhoramento de óleo em milho (HALLAUER \& MIRANDA FILHO, 1981).

\subsection{Progressos esperados com a seleçáo para caracteres da planta}

O objetivo principal do uso do Delineamento l é estimar variáncias e covariâncias, principalmente as variâncias e covariáncias aditivas e de dominâncias. Somente a título de exercício serão estimados os progressos esperados para os caracteres avaliados. Deve-se considerar também que, para RE, não foi possivel o cálculo dos progressos esperados com a seleção massal devido a auséncia da estimativa da variância fenotípica dentro de progénies, o que impossibilita estimar a variância fenotípica entre plantas.

Deve-se ainda considerar que a seleção para o TO (caráter principal deste trabalho) poderá ser feita em um só sexo sem grande prejuizo, devido ao pequeno efeito da fonte polinizadora neste caráter (MILLER \& BRIMHALL, 1951; CURTIS et alii 1956; ALEXANDER \& LAMBERT, 1968 e BATISTA \& TOSELLO, 1982) e o acentuado efeito matemo (MILLER \& BRIMHALL, 1951; CURTIS et ali, 1956; JELLUM, 1966; GARWOOD et alii, 1970; BATISTA \& TOSELLO, 1982). 
As estimativas dos progressos esperados com a selęão massal em um só sexo e intensidade de $10 \%$ e com seleção entre famillias de meios irmãos com sementes remanescentes e intensidade de 20\% são apresentados nas Tabelas 8 e 9.A obtenģão das estimativas dos ganhos esperados com a seleção de famillias de meios irmãos baseou-se no fato de que a variância entre machos no delineamento I corresponde a variância entre famílias de meios irmãos (conforme exposto em material e métodos).

Os progressos esperados com a seleção entre famílias de meios irmãos (20\%) foi superior àqueles esperados com a seleção massal (10\%) para todos os caracteres, exceto para TO da população Piranão VD-2 onde ocorreu o inverso. Este fato é explicado devido as baixas herdabilidades a nivel de plantas individuais em relação às herdabilidades ao nivel de médias de famillias de meios irmãos dos caracteres.

O estudo dos ganhos genéticos em muitos dos caracteres aqui considerados pode não ter uma aplicação direta, mas os progressos obtidos neles associados a ganhos em outros, pode fornecer informaçōes sobre caracteres de diflcil avaliação; ou ainda, a alta correlação entre caracteres pode alterar a importância de um caráter. Assim DS, que por si só parece não importante, quando associado ao DE assume papel de importância quando se pensa em melhorar a profundidade do grão. Cuidados deverão ser dispensados para evitar aumentos na altura de planta e de espiga quando se pensa em melhorar o rendimento de espiga.

Os ganhos esperados com seleção massal e seleção de famillias de meios irmãos de todos os caracteres (exceto TO e CE) da população Piranão VF-1 foram superiores àqueles da Piranão VD-2 (Tabela 8 e 9).

Os progressos esperados com a seleção de familias de meios irmãos para RE na população Piranão VD-2 foram semelhantes aqueles observados por SANTOS \& NASPOLINI (1986), SOARES FILHO, (1987), ANDRADE (1988) e BIGOTTO (1988), enquanto os ganhos esperados da Piranão VF-1 se aproximam mais dos resultados de RISSI (1980), SOUZA JR. (1983), SANTOS (1985) e SAMPAIO (1986). Na população Piranão VD-2, foram estimados ganhos de seleção para RE inferiores em $50 \%$ aqueles calculados para a população Piranão VF-1. Proporção idêntica foi obtida por SOARES FILHO (1987) entre os ganhos da população Piranão VD-2B em relação a Piranão VF-1B. 
Independente do processo de seleção, os ganhos esperados de seleção para $A P$ e $A E$ foram baixos e menores ainda na população Piranão VD-2. Os valores percentuais dos ganhos de seleção por ciclo para AP foram próximos aqueles obtidos por AYALA OSUNA (1977); AGUILAR-MORAN (1984) e ANDRADE (1988) enquanto aqueles observados para AE se aproximaram dos obtidos por AYALA OSUNA (1977) e ANDRADE (1988). Os ganhos de seleção para AP e AE são, em geral, superiores aos Gs obtidos neste estudo.Estes desejáveis e baixos Gs estimados talvez tenham sido uma consequência das alterações na variância aditiva provocada pela seleção para óleo efetuada nessas populações.

Praticamente não houve diferença entre os Gs esperados obtidos nos dois sistemas seletivos e nas duas populações para o P100, uma vez que este carater apresenta alta herdabilidade. Os ganhos percentuais de seleção que variaram de $3,64-5,51 \%$ não diferiram daqueles obtidos por QUEIROZ (1969), MOTA (1974) e ZIMBACK (1985).

\subsubsection{Progressens esperados com a seleçāo para teor de óleo em milho}

Considerando a herdabilidade média a alta observada para teor de óleo e que este é influenciado pelo genótipo do grão, esquema simples de seleção (seleção massal), com ênfase na seleção de grãos individuais, são os mais adequados métodos para o melhoramento de óleo em milho (PONELEIT \& BAUMAN, 1970; DUDLEY, 1977 e HALLAUER \& MIRANDA FILHO, 1981).

Apesar de bem próximos,os ganhos esperados com seleção massal foram superiores àqueles da seleção entre famillias de meios irmãos na população Piranão VD-2. Estes resultados estão de acordo com os obtidos por ZIMBACK (1985) na população Dentada braquítica opaco-2 e por BIANCO (1984) nas populaçōes Piranāo VD-2 e Piranão VF-1. MILLER et alii (1981), no entanto observaram maiores ganhos na seleção entre e dentro de familias de melos irmáos em relaçăo a seleçăo massal na variedade "Reid Yellow Dont": A contradição dos resultados obtidos por estes autores em relaçāo aos deste trabalho provavelmente se deve ao uso da seleção dentro de progênies de meios irmãos empregada por MILLER et alii (1981) e não considerada no presente estudo. Praticamente não houve diferença entre os progressos esperados com seleção massal e seleção entre familias de meios irmãos para a população Piranão VF-1. 
Os ganhos percentuais esperados na seleção de famílias de meios irmãos para TO da população Piranão VD-2 foram superiores àqueles da população Piranão VF1; esta mesma situação foi detectada por BIANCO (1984), nas mesmas populações, embora os ganhos esperados observados pelo autor tenham sido superiores. Isto provavelmente devido à exploração da variabilidade dentro de progênies (seleção dentro com 10\% de intensidade).

A média de oito estimativas de progressos esperados com a seleção em diferentes populações foi de 4,47\% (Tabela 3 - Apêndice). A população Piranão VD-2 apresentou ganhos percentuais esperados um pouco acima, enquanto a Piranão VF-1 abaixo desta média.

Uma vez que a população Piranão VD-2 apresenta TO médio inferior ao da Piranão VF-1 e tendo-se em vista que ocorre o inverso em relação aos valores de Gs esperados para este carater, espera-se que dentro de poucos ciclos de seleção as duas populações alcancem a mesma concentração média em óleo; se a mesma situação (embora em sentido contrário) foi detectada em relação ao RE, pode-se supor que o equilíbrio ocorra também para o rendimento em óleo (t/ha).

\subsection{Associação entre caracteres}

Nas Tabelas 10 e 11 encontram-se os produtos médios referentes às combinações entre o teor de óleo e 11 caracteres da planta da população Piranão VD-2 e da Piranão VF-1 respectivamente. Os produtos médios referentes às combinações entre o rendimento de espiga e dez caracteres da planta destas populações são apresentados na Tabela 12 e 13. A partir destes produtos médios, calculou-se as estimativas das covariâncias genéticas ambientais e fenotípicas, particularmente a covariância aditiva $\left(\mathrm{COV}_{A}\right)$ e covariância fenotípica de médias de famílias de meios irmãos (COVF) entre o teor de óleo e 11 caracteres da planta (Tabelas 14 e 15) e entre rendimento de espiga e dez caracteres da planta nas populações Piranão VD-2 e Piranão VF-1, (Tabelas 16 e 17) que juntamente com as respectivas variância aditiva e variância entre médias de família de meios irmãos resultaram nos coeficiente de correlação genética aditiva $\left(r_{A}\right)$ e nos coeficientes de correlação fenotîpica ao nível de médias de progênies de meios irmãos ( $\left.r_{F}\right)$. 


\subsubsection{Correlaçōes genéticas e fernotipicas entre rendimento de espiga e outros caracteres} da planta

As principais causas da existência de correlação entre caracteres são a pleiotropia e a ligação gênica, tendo esta última uma importancia relativamente alta quando se tem uma população resultante do cruzamento de diferentes populações (FALCONER, 1964).

Conforme o esperado a exemplo do que tem sido verificado em certos trabalhos (MURTY \& ROY, 1957; AGUILAR MORÁN, 1984; MARTINS, 1986, SOARES FILHO, 1987), o rendimento de espiga e o peso de grãos (PG) são positivamente correlacionados. Considerando-se que o PE na pratica nada mais é do que outra forma de se expressar o $R E$, era de se esperar também uma alta correlação entre os caracteres rendimento de espiga e peso de espiga. Altas correlações genéticas aditiva $\left(r_{A}\right)$ e fenotípica a nível de médias de progênies de meios irmãos $\left(r_{F}\right)$ entre o RE e os caracteres $P E$ e $P G$ foram observadas nas duas populações. A correlação entre RE e P100 foi também positiva, embora não tão elevada quanto as anteriores, mas bem próximas àquelas observadas por EL ROUBY \& PENNY (1967) e DUDLEY et alii (1977)(Tabela 18).

Quanto às associações de natureza tanto genética como fenotípica, entre rendimento de grãos e a altura de planta e ou da espiga, estas, em regra, têm-se mostrado positivas, segundo foi constatado por diversos autores em diferentes populações ou variedades (MURTY \& ROY, 1957; EL ROUBY \& PENNY, 1967, OBILANA \& HALLAUER, 1974; LIMA \& PATERNIANI, 1977; CRISÓSTOMO, 1978; HALLAUER \& MIRANDA FILHO, 1981; AGUILAR MORÁN, 1984; ANDRADE et alii, 1986 e SAMPAIO, 1986). Dentre estas pesquisas foram observados coeficientes de correlação com valores bastante variáveis, e em alguns casos bem baixos. Assim, as perspectivas de redução da altura da planta e da espiga sem consequentes prejulzos no rendimento de grãos são muito animadoras. A este respeito, os resultados obtidos por PATERNIANI (1967), CIMMYT (1972), ANDRADE et alii (1986) e SOARES FILHO (1987) atestam a viabilidade desta prática. Como se sabe, a redução do porte da planta, principalmente a altura da espiga, causa um rebaixamento do centro de gravidade da planta, tornando-a mais resistente ao acamamento. 
Complementando, o trabalho conduzido por MURTY \& ROY (1957) alerta para o fato de que a associação positiva comumente verificada entre porte e o rendimento de milho resultar em verdade do número de folhas relativamente superior normalmente encontrado em plantas de maior altura; fundamenta-se esta colocação em informações alcançadas a partir do cálculo de correlações fenotípicas simples e parciais, cujos conteúdos demonstraram que o grau de associação entre rendimento de grãos e a altura da planta é sensivelmente reduzido quando se isola do processo de sua determinação a influência do número de folhas.

Cabe acrescentar que TOLLENAAR (1977), em revisão bibliográfica dirigida às relações existentes entre o rendimento e o armazenamento de substâncias essenciais ao desenvolvimento do milho, enfatiza que a área foliar por planta é um dos principais fatores responsáveis pelo suprimento de produtos assimiláveis pelos grãos. Diante disto, depreende-se que a redução do porte da planta mediante o emprego do gene br2 constitui sem dúvida em alternativa altamente viável, uma vez que sua introdução de porte normal não é acompanhada por modificações na área foliar.

Os coeficientes de correlação entre rendimento e o porte da planta (AP e $A E)$, com exceção do $r_{A}$ entre RE e $A E$ da população Piranão VD-2, foram baixos, possibilitando assim melhorar o rendimento de espiga sem grandes alterações na AP e AE da população Piranão VF-1 ou sem alterar a AP da Piranão VD-2 (Tabela 18).

Informações provenientes da literatura revelam que em regra o rendimento em grãos tende a se associar positivamente a nivel fenotípico e genético com diâmetro ou circunferência da espiga, comprimento da espiga diâmetro ou circunferência do sabugo (ROBINSON et alii, 1951; MURTY \& ROY, 1957; OBILANA et alii, 1979; HALLAUER \& MIRANDA FILHO, 1981; MARTINS, 1986). No entanto, correlação negativa entre RE e os caracteres DE e DS foram observadas por SOARES FILHO(1987). Segundo este autor os valores negativos obtidos se deve ao reduzido número de plantas amostradas por parcela $(n \leq 5)$ para estes caracteres que apresentam baixa herdabilidade.

Os caracteres NF, GF, DE, CE e DS são componentes importantes do PE. Uma vez que existe uma alta correlação positiva entre RE e PE, era de se esperar, como 
foi verificado nas duas populações, correlação positiva entre o RE e aqueles caracteres (Tabela 19).

A população Piranão VD-2 apresentou valores maiores de correlações entre RE e os caracteres PE, PG, NF, DS e AE e menores correlações entre o RE e os caracteres P100, GF, DE, CE e AP em relação a populą̧ão Piranão VF-1.

\subsection{Correlaçöes genéticas e fenotípicas entre o teor de óleo e caracteres da planta}

Dos coeficientes de correlação genético aditivo $\left(r_{A}\right)$ e fenotípico a nível de médias de progênies de meios irmãos $\left(r_{F}\right)$, apresentados na Tabela 19, sómente aqueles entre TO e os caracteres RE, AP e AE foram semelhantes, nas duas populações; os demais coficientes diferiram em magnitude e ou em sinal de uma população para outra. Como pode ser observado, existe uma correlação positiva (média a baixa) entre o TO e os caracteres RE, AP e AE nas populações avaliadas.

Correlações positivas entre TO e RE foram também obtidas por vários autores (MILLER \& BRIMHALL, 1951; GUPTA et alii, 1975; MILLER et alii, 1981; BIANCO, 1984 e ZIMBACK, 1985). Em geral, à medida que se processa o melhoramento para o teor de oleo de uma população parece haver uma tendência de alterações das ligações entre genes para rendimento de espiga e genes para teor de óleo. Desta forma, DUDLEY et alii (1974) e MILLER et alii (1981) estabeleceram um valor próximo a 7\% como sendo o limite máximo que se pode aumentar o teor de óleo, sem haver grandes alterações no rendimento de espiga. Valores de TO superiores a este seriam conseguidos, segundo os autores, às custas de reduções no RE. Em populações com alto TO, a correlação entre rendimento e TO é negativa é pode atingir valores tão altos quanto -0,96, observado por MISEVIC \& ALEXANDER, (1989).

Considerando a estreita relação entre RE, PE e PG era de se esperar que houvesse uma correlação positiva mais elevada entre TO e os caracteres PE e PG, do que a ocorrida na população Piranão VF-1, mas que não fosse tão alta quanto a observada na população Piranão VD-2. Não é possivel estabelecer o quanto destas divergências poderiam ser explicadas pelos reduzidos números de plantas amostradas dentro de parcelas $(n \leq 5)$ e de fêmeas por machos usados no delineamento I $(K=3,1)$ para os caracteres PE e PG, que sofrem grande influência do ambiente. 
As correlações negativas observadas entre TO e AP e TO e AE obtidas por MISEVIC \& ALEXANDER (1989), em populações com alto teor de óleo, contrastam com aquelas observadas no presente estudo. Em concordância com os resultados deste trabalho, foram observadas correlações positivas entre o teor de óleo e altura de planta e entre teor de óleo e altura de espiga (BIANCO, 1984) nas populações Piranão VD-2 e Piranão VF-1. As correlações obtidas pelos referidos autores, bem como as listadas na Tabela 19 entre TO e os caracteres $A P$ e $A E$, possuem idênticos magnitudes e sinais daquelas observadas entre RE e TO.

O baixo valor de correlação positiva observado entre TO e P100 na população Piranão VF-1 é comparável com aqueles obtidos por ALEXANDER \& SEIF (1963); BATISTA \& TOSELLO (1979) e TOSELLO \& GERALDI (1980b). No entanto a alta correlação entre os dois caracteres da população Piranão VD-2 só é semelhante ao valor de 0,88 obtido para a correlação entre teor de óleo e peso de 500 grãos obtido por MISEVIC \& ALEXANDER (1989).

Considerando que a população Piranão VF-1 com teor de óleo de 5,06\% tenha sido mais melhorada ou respondido mais o processo de melhoramento para este caráter do que a população Piranão VD-2 que se encontra com $4,79 \%$ de óleo e que a medida que se intensifica a seleção reduz-se os coeficientes de correlação entre TO e P100, explica-se assim a maior correlação entre TO e P100 ocorrida na popula̧̧ão Piranão VD-2.

A alta correlação negativa entre TO e CE obtida por MISEVIC \& ALEXANDER (1989), no sintético Alexho, aproxima-se mais da correlação entre estes caracteres obtida na população Piranão VF-1, enquanto a correlação entre TO e NF de 0,37 , observada pelo mesmo autor, é mais próxima daquela observada na Piranão VD-2 entre o teor de óleo e o número de fileiras de grãos.

Considerando-se as altas discrepâncias ocorridas entre os valores das correlações entre TO e os caracteres NF, GF, DE, CE e DS nas duas populações e tendo-se em vista a escassez de avaliações similares na literatura, não se pode afirmar que tais diferenças sejam de origem genética. Talvez o mais lógico seja supor que os valores de correlação tenham sido ocasionados por problemas de amostragens (SOARES FILHO, 1987) e ou reduzido número de fêmeas por machos usados no delineamento I (MARQUEZ-SANCHEZ \& HAL- 
LAUER, 1970). Portanto, sugere-se o uso de amostras com maior número de plantas e, no caso do se empregar o delineamento I, deve-se fazê-lo com um número maior de fêmeas por machos, nos estudos que envolvam os caracteres NF, GF, DE, CE e DS, antes de se admitir e tentar explicar que na populạão Piranão VD-2 existe alta correlação positiva entre TO e os caracteres DS e CE, enquanto estes valores são negativos na população Piranão VF-1. As diferenças entre as médias do TO, CE e DS associada às diferenças genéticas populacionais não são suficientes para explicar este fato.

\subsubsection{Respostas correlacionadas esperadas com a seleçáo}

A resposta correlacionada esperada com a seleção será aqui analisada sob dois aspectos básicos e tendo o teor de óleo como o caráter principal em ambas considerações. No primeiro caso, serão consideradas as respostas correlacionadas nos diversos caracteres quando se faz a seleção para TO. Assim, são verificadas as alteraçōes previstas nos diferentes caracteres das populações braquiticas avaliadas neste trabalho em função da seleção praticada para o TO. Estes prognósticos além de teóricos, restringem-se a ambientes análogos àqueles em que as populações ou variedades em questão tenham sido investigadas. $\mathrm{O}$ outro aspecto seria as variações no TO quando a seleção é voltada para outros caracteres que não ele próprio. Este tipo de resposta é que fundamenta e viabiliza a execução de seleção indireta de caracteres que são pouco sensiveis ao melhoramento. $O$ êxito desta técnica alternativa depende de duas condiçoes: 1) o caráter secundário objeto de seleção deve possuir herdabilidade superior ao do principal; 2) a correlação genética entre ambos deve ser elevada (FALCONER, 1964; GERALDI et alii, 1975; VENCOVSKY, 1987). Tomando-se dois caracteres quaisquer, chamando de $\mathrm{x}$ o principal e y o secundário, a seleção indireta de $\mathrm{x}$ com base em y será mais eficiente que a direta desde que :

$\left.r_{A} A, y\right) \cdot$ hy $h x$ onde $r_{A}(x, y)$ refere-se à correlação genética aditiva entre $x$ e $y$ e hx e hy correspondem à raiz quadrada dos coeficientes de herdabilidade de $x$ e y respectivamente (FALCONER, 1964).

A maior herdabilidade do TO em relação aos demais caracteres, não satisfazendo assim a primeira das condições da seleção indireta impossibilitou a ocorrência de ganhos indiretos ou respostas correlacionadas no teor de óleo, com a seleção feita em 
11 caracteres da planta (Tabela 20), superiores ao ganho de seleção direta no TO (Tabela 9); houve ganhos indireto negativos ou redução no teor de óleo quando a seleção foi feita no GF da população Piranão VD-2 e NF, CE e DS da Piranão VF-1.

A alta herdabilidade do TO e sua elevada correlaçáo com os caracteres PE, PG, CE, DS e AP levou a obtenção de respostas correlacionadas (RPE/TO; RPG/TO;

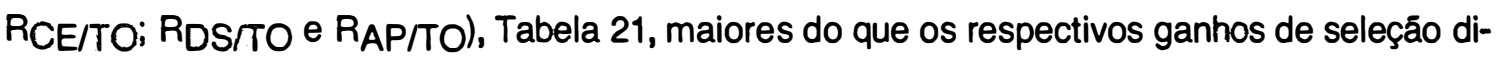
reta para os caracteres PE, PG, CE, DS e AP da população Piranão VD-2 (Tabela 9).

As informaçóes da Tabela 21 evidenciam o aspecto desejável do aumento do rendimento à medida que se seleciona para TO e os cuidados que deverão ser tomados para evitar os aumentos nas alturas de plantas e de espiga que acompanha este processo.

A seleção para TO provocou reduçóes do NF em ambas as populaçōes do GF na Piranão VD-2 e do DE e DS na população VF-1.

A redução do NF e GF da população Piranão VD-2 e do NF, CE e DS da população Piranão VF-1 não se adequaram aos ganhos no rendimento de espiga provocados pela seleģão no teor de óleo, a não ser é claro que tais componentes de produção não sejam tão importantes. 


\section{CONCLUSÕES}

Os resultados obtidos neste trabalho permitiram a formulação das seguintes conclusōes:

a) As médias fenotipicas dos caracteres rendimento de espiga, altura de planta e altura de espiga das populaçōes Piranáo VD-2 e Piranão VF-1 revelaram-se compatíveis com o esperado em milhos comerciais de porte baixo. $O$ teor de óleo das populaçóes se encontra em um nivel superior ao dos híbridos Ag 352-B e DEK XL 540.

b) Os caracteres peso de espiga, peso de grãos, peso de 100 grăos, número de fileiras de grãos por espiga, número de grăos por fileira, diâmetro de espiga e diâmetro de sabugo das duas populaçōes apresentaram médias fenotípicas compativeis com aquelas observadas por outros pesquisadores nas mesmas populaçōes e ou populaçōes semelhantes.

c) As populaçōes estudadas apresentaram variáncia aditiva suficiente para o melhoramento de praticamente todos os caracteres avaliados, à exceçăo do número de grâos por fileira, diâmetro de espiga, peso de espiga, número de fileiras de grăo por espiga, diâmetro de sabugo e altura da planta da população Piranão VD-2, sendo tais perspectivas, em termos genéricos, mais promissoras na Piranão VF-1. 
d) A população Piranão VF-1 apresentou estimativas de herdabilidade dos caracteres rendimento de espiga, peso de grãos, peso de espiga, peso de 100 grãos, número de fileiras de grão por espiga, número de grãos por fileira, diâmetro de espiga, diâmetro de sabugo, altura de planta e altura de espiga superiores aos da Piranão VD-2. O contrário ocorreu para herdabilidade de teor de óleo e comprimento de espiga, em que as maiores estimativas foram observadas na população Piranão VD-2.

e) Os resultados obtidos, particularmente aqueles relacionados à presença de variância de dominância dos caracteres número de fileiras de grão por espiga, comprimento de espiga, diâmetro de sabugo e teor de óleo das duas populações, diâmetro de espiga da Piranão VD-2 e rendimento de espiga da população Piranão VF-1 ampliam as perspectivas de suœesso na criação de hilbridos nas duas populações com relação a esses caracteres.

f) Os ganhos esperados com a seleção de famílias de meios-irmãos foram superiores àqueles obtidos com seleção massal para todos os caracteres das duas populações, exceto para teor de óleo da Piranáo VD-2. Os progressos esperados para todos os caracteres, exceto para teor de óleo e comprimento de espiga da população Piranão VF-1 foram superiores àqueles da Piranão VD-2.

g) Devido a alta correlação genética e fenotípica existente entre rendimento de espiga e peso de grãos e a semelhante variação destes caracteres, as pesquisas voltadas para rendimento de grãos poderão basear-se somente no rendimento de espiga, dada à sua maior facilidade de mensuração.

h) O rendimento de espiga apresentou correlação positivacom todos os outros caracteres avaliados nas duas populaçōes. Na população Piranão VD-2 ocorreram as maiores correlaçōes entre rendimento de espiga e os caracteres peso de espiga, peso de grãos, número de fileiras de grão por espiga, diâmetro de sabugo e altura de espiga e as menores entre rendimento de espiga e os caracteres peso de 100 grãos, número de grãos por fileira, diâmetro de espiga, comprimento de espiga e altura de planta em relação àquelas observadas na população Piranão VF-1. O melhoramento do rendimento de espiga provocará, invariavelmente, um aumento da altura de planta e altura de espiga. 
i) Todos os caracteres da população Piranão VD-2 foram positivamente correlacionados com o teor de óleo. As correlaçőes entre o teor de óleo e os caracteres rendimento de espiga, peso de espiga, peso de grăos, peso de 100 grăos, número de grăos por fileira, diâmetro de espiga, altura de planta e altura de espiga da população Piranão VF-1 foram também positivas, embora de menor magnitude. Foi observada uma baixa correlạ̧áo negativa entre o teor de óleo e os caracteres nưmero de fileiras de grăo por espiga, comprimento de espiga e diámetro de sabugo da Piranão VF-1.

j) Foi observada uma baixa correlạão positiva entre o teor de óleo e os caracteres rendimento de espiga, altura de planta e altura de espiga das duas populações braquíticas. Assim, obtêm-se, com facilidade, aumentos no rendimento de espiga, quando na condução de um programa de melhoramento para elevar o teor de óleo. O aumento da altura de planta e altura de espiga pode náo ser problemático, haja vista a presença do gene braquítico nas populaçōes.

1) As respostas correlacionadas nos caracteres peso de espiga, peso de grăos, comprimento de espiga, diâmetro de sabugo e altura de planta com a seleção para teor de óleo foram maiores que os ganhos na seleção direta destes caracteres da população Plranão VD-2. Na população Piranão VF-1, nenhum caráter apresentou ganho indireto superior ao direto com a seleção para teor de óleo. 


\section{REFERÊNCIAS BIBLIOGRÁFICAS}

AGUILAR MORÁN, J.F. Avaliação do potencial genético de linhagens e respectivos testadores obtidos de duas populações de milho (Zea mays L.). Piracicaba, 1984, 118p. (Mestrado Escola Superior de Agricultura "Luiz de Queiroz"(USP).

ALEXANDER, D.E. Breeding special nutritional and industrial types. In: SPRAGUE, G.F. \& DUDLEY, J.W.,ed. Com and com improvement. 2. ed. Madison, American Society of Agronomy, 1988. p. 869-80.

ALEXANDER, D.E. \& LAMBERT, R.J. Relationship of kernel oil content to yield in maize. Crop Science, Madison, 8:273-4, 1968.

ALEXANDER, D.E. \& SEIF, R.D. Relation of kernel oil content to some agronomic traits in maize. Crop Science, Madison, 3: 354-5, 1963.

ALEXANDER, D.E.; DUDLEY, J.W.; CREECH, R.G. Corn breeding and genetics. In: INGLETT, G.E., ed. Corn; culture processing, products. New York, The Avi. Pub. Compl., 1970. p. 6-23.

ALLARD, R.W. Principios do melhoramento genético das plantas. Sảo Paulo, Edgar Blucher, 1971. 381p. 
ANDRADE, J.A.C. Seleção divergente para tamanho do pendão e posição da espiga na população ESALQ-PB-1 de milho (Zea mays L). Piracicaba, 1988, 136p. (Mestrado - Escola Superior de Agricultura "Luiz de Queiroz"/USP).

ANDRADE, J.A.C.; MIRANDA FILHO, J.B.; GERALDI, 1.O.: SOUZA JUNIOR, C.L Seleção divergente para o número de ramificaçōes de pendão e altura de espigas na população ESALQ-PB1 de milho. In: CONGRESSO NACIONAL DE MILHO E SORGO, 16 s, Sete Lagoas, MG, 1986. Resumos, Sete Lagoas, EMBRAPA-CNPMS. 1986. p. 57-8.

ARNOLD, J.M.; BAUMAN, LF.; MAKONNEN, O. Physical and chemical kernel characteristics of normal and opaque-2 endosperm maize hybrids. Crop Science, Madison, 17:362-6, 1977.

ARNOLD, J.M.; PIOVARCI, A.; BAUMAN, L.F.; PONELEIT, C.G. Weight, oil and fatty acid composition of components of normal opaque-2 and floury-2 maize kernels. Crop Science, Madison, 14: 598-9, 1974.

AYALA OSUNA, J. Avaliação da seleção massal estratificada combinada com despendoamento de plantas inferiores em duas populações de Zea mays L (milho) e de heterose dos seus cruzamentos. Jaboticabal, 1977. 138p. (Livre Docência. Faculdade de Ciências Agrárias e Veterinárias de Jaboticabal/UNESP).

BARREN, E.T.; SQUIRES, C.; STUMPF, P.K. Fat metabolism in higher plants; 15. Enzymatic synthesis of fatty acids by an extract of avocado mesocarp. Joumal of Biological Chemistry, Baltimore, 236. 2610-4, 1961.

BARTUAL, R. \& HALLAUER, A.R. Variability among unselected maize inbred lines developed by full sibbing. Maydica. Bergamo, 21: 46-60, 1976. 
BATISTA, L.A.R. Seleção para tamanho do embrião relacionada com o teor de óleo do grão de milho (Zea mayz L.). Piracicaba, 1980. 72p. (Mestrado - Escola Superior de Agricultura "Luiz de Queiroz"/USP ).

BATISTA, L.A.R. Uso de sementes autofecundadas e de polinização livre no melhoramento do conteúdo de óleo em duas subpopulações de milho (Zea mays L). Piracicaba, 1981. 72p. (Doutorado - Escola Superior de Agricultura "Luiz de Queiroz"/USP).

BATISTA, L.A.R. \& TOSELLO, G.A. Correlações fenotípicas entre a percentagem de óleo, peso volume e densidade dos grãos de milho (Zea mays L.). Relatório Cientffico do Departamer to de Genética, ESALQ, Piracicaba, 13:44-52, 1979.

BATISTA, L.A.R. \& TOSELLO, G.A. Influência da fonte polinizadora sobre o conteúdo de óleo em grãos de milho. Pesquisa Agropecuśria Brasileira, Brasília, 17: 1757-62, 1982.

BAUMAN, LF. Germ and endosperm variability, mineral elements and modifier genes in opaque-2 maize. In: INTERNATIONAL SYMPOSIUM ON PROTEIN QUALITY IN MAIZE, 1., EI Batan, 1972. Proceedings. Purdue, CIMMYT, 1975. p.217-27.

BAUMAN, L.F.; CONWAY, T.F.; WATSON, S.A. Inheritance of variations in oil content of individual corn (Zea mays L) kernels. Crop Science, Madison, 5: 137-8, 1965.

BEADLE, J.B., JUST, D.E.; MORGAN, R.E.; REINERS, R.A. Composition of corn oil. Joumal of the American Oil Chemists Society, Chicago, 42: 90-5, 1965.

BENITEZ TORRES, L Avaliação de progênies de irmãos germanos obtidos por cruzamento em cadeia em duas populações de milho (Zea mays L). Piracicaba, 1986. 102p. (Mestrado Escola Superior de Agricultura "Luiz de Queiroz"(USP).

BIANCO, S. Avaliação do potencial genético de populações de milho (Zea mays, L) braquítico para o teor de óleo na semente. Piracicaba, 1984. 98p. (Mestrado - Escola Superior de Agricultura "Luiz de Queiroz"/USP). 
BIGOTO, C.A. Estudo da população ESALQ-PB-1 de milho (Zea mays, L) em cinco ciclos de seleçăo recorrente. Piracicaba, 1988. 124p. (Mestrado - Escola Superior de Agricultura,"Luiz de Queiroz"/USP).

BRIDGES, J.R. \& KNAPP, S.J. Probabilities of negative estimates of genetic variances. Theoretical and Applied Genetics, Berlin, 24: 269-74, 1987.

BRINK, R.A. \& COOPER, D.C. The endosperm in seed development. Botanical Review, New York, 13: 423-54, 1947.

BRUNSON, A.M.; EARLE, F.R.; CURTIS, J.J. Interrelations among factors influencing the oil content of corn. Joumal American Society Agronomy, Geneva, 40. 180-5, 1948.

CANTON, T. Avaliação de oito ciclos de seleção recorrente na população de milho (Zea mays L) Suevan DMR. Piracicaba, 1988. 112p. (Mestrado - Escola Superior de Agricultura "Luiz de Queiroz"(USP).

CASTRO, E.M. Competição entre populaçōes de milho normais e braquíticas. Piracicaba, 1983. 155p. (Doutorado - Escola Superior de Agriculura, "Luiz de Queiroz"/USP).

CENTRO INTERNACIONAL DE MEJORAMIENTO DE MAIZ Y TRIGO. Maiz-mejoramiento genético. In: Informe Anual Chapingo, 1972. p.94-103.

COCHRAN, W.G. \& COX, G.M. Experimental designs. 2. ed. New York, John Wiley, 1957. $611 p$.

COMSTOCK, R.E. \& ROBINSON, H.F. The components of genetic variance in populations of biparental progenies and their use in estimating the averege degree of dominance. Biome trics, Washington, 4: 254-66, 1948. 
COMSTOCK, R.E. \& ROBINSON, H.F. Experiments for estimation of the average combinance of genes affecting quantitative characters. in: GOWEN, J.W., ed. Heterosis. Ames, lowa State College, 1952. p. 494-516.

CRISÓSTOMO, J.R. Estimação de parâmetros genéticos visando seleção em dois compostos de milho (Zea mays L). Piracicaba, 1978, 71p. (Mestrado - Escola Superior de Agricultura "Luiz de Queiroz"(USP).

CURTIS, J.J.; BRUNSON, A.M.; HUBBARD, J.E.; EARLE, F.R. Effect of the pollen parent on oil content of com kernel. Agronomy Joumal, Madison, 4\&:551-5, 1956.

CURTIS, P.E.; LENG, E.R. ; HAGEMAN, R.H. Developmental changes in oil and fatty acid content of maize strains varying in oil content. Crop Science, Madison, \& 689-93, 1968.

DUDLEY, J.W. Seventy six generations of selection for oil and protein percentage in maize. In: INTERNATIONAL CONFERENCE ON QUANTITATIVE GENETICS, 2., Ames, 1976. Proceedings. Ames, lowa State University, 1977. p.459-74.

DUDLEY, J.W. \& LAMBERT, R.J. Genetic variability after 65 generations of selection in Illinois oil and protein strains of Zea mays L. In: DUDLEY, J.W., ed. Seventy generations of selections for oil and protein in maize Madison, Crop Science Society of América, 1974. p.175-80.

DUDLEY, J.W.; LAMBERT, R.J.; ALEXANDER, D.E. Seventy generations of selection for oil and protein concentration in the maize kemel. In: DUDLEY, J.W. ed. Seventy generations of selection for oil and protein in maize Madison, Crop Science Society os America, 1974. p.181-211. 
BIGOTO, C.A. Estudo da população ESALQ-PB-1 de milho (Zea mays, L.) em cinco ciclos de seleção recorrente. Piracicaba, 1988. 124p. (Mestrado - Escola Superior de Agricultura,"Luiz de Queiroz"(USP).

BRIDGES, J.R. \& KNAPP, S.J. Probabilities of negative estimates of genetic variances. Theore tical and Applied Genetics, Berlin, 24: 269-74, 1987.

BRINK, R.A. \& COOPER, D.C. The endosperm in seed development. Botanical Review, New York, 13: 423-54, 1947.

BRUNSON, A.M.; EARLE, F.R.; CURTIS, J.J. Interrelations among factors influencing the oil content of corn. Jounal American Society Agromomy, Geneva, 40: 180-5, 1948.

CANTON, T. Avaliação de oito ciclos de seleção recorrente na população de milho (Zea mays L.) Suevan DMR. Piracicaba, 1988. 112p. (Mestrado - Escola Superior de Agricultura "Luiz de Queiroz"/USP).

CASTRO, E.M. Competição entre populações de milho normais e braquíticas. Piracicaba, 1983. 155p. (Doutorado - Escola Superior de Agriculura,"Luiz de Queiroz"/USP).

CENTRO INTERNACIONAL DE MEJORAMIENTO DE MAIZ Y TRIGO. Maiz-mejoramiento genético. In: . Informe Anual. Chapingo, 1972. p.94-103.

COCHRAN, W.G. \& COX, G.M. Experimental designs. 2. ed. New York, John Wiley, 1957. $611 p$.

COMSTOCK, R.E. \& ROBINSON, H.F. The components of genetic variance in populations of biparental progenies and their use in estimating the averege degree of dominance. Biometrics, Washington, 4: 254-66, 1948. 
COMSTOCK, R.E. \& ROBINSON, H.F. Experiments for estimation of the average combinance of genes affecting quantitative characters. In: GOWEN, J.W., ed. Heterosis. Ames, lowa State College, 1952. p. 494-516.

CRISÓSTOMO, J.R. Estimação de parâmetros genéticos visando seleção em dois compostos de milho (Zea mays L). Piracicaba, 1978, 71p. (Mestrado - Escola Superior de Agricultura "Luiz de Queiroz"/USP).

CURTIS, J.J.; BRUNSON, A.M.; HUBBARD, J.E.; EARLE, F.R. Effect of the pollen parent on oil content of com kernel. Agronomy Journal, Madison, 48: 551-5, 1956.

CURTIS, P.E.; LENG, E.R. ; HAGEMAN, R.H. Developmental changes in oil and fatty acid content of maize strains varying in oil content. Crop Science, Madison, 8:689-93, 1968.

DUDLEY, J.W. Seventy six generations of selection for oil and protein percentage in maize. In: INTERNATIONAL CONFERENCE ON QUANTITATIVE GENETICS, 2., Ames, 1976. Proceedings. Ames, lowa State University, 1977. p.459-74.

DUDLEY, J.W. \& LAMBERT, R.J. Genetic variability after 65 generations of selection in Illinois oil and protein strains of Zea mays L In: DUDLEY, J.W., ed. Seventy generations of selec tions for oil and protein in maize. Madison, Crop Science Society of América, 1974. p.175-80.

DUDLEY, J.W.; LAMBERT, R.J.; ALEXANDER, D.E. Seventy generations of selection for oil and protein concentration in the maize kemel. In: DUDLEY, J.W. ed. Seventy generations of se lection for oil and protein in maize. Madison, Crop Science Society os America, 1974. p.181-211. 
DUDLEY, J.W.; LAMBERT, R.J.; ROCHE, J.A. Genetic analysis of crosses among strains divergently selected for percent oil and protein. Crop Science, Madison, 17: 111-7, 1977.

EARLE, F.R.; CURTIS, J.J.; HUBBARD, J.E. Composition of the cornponent parts of the corn kemel. Cereal Chemistry, St. Paul, 23 : 504-11, 1956.

EBERHART, S.A.; MOLL, R.H.; ROBINSON, H.F.; COCKERHAM, C.C. Epistatic and other variances in two varieties of maize. Crop Science. Madison, 6:275-80, 1966.

EL-LAKANY, M.A. \& RUSSELL, W.A. Relationship of maize characters with yield in testcrosses of inbreds at different densities. Crop Science. Madison, 11: 698-701, 1971.

EL ROUBY, M.M. \& PENNY, LH. Variation and covariation in high oil population of corn (Zea mays L) and their implications in selection. Crop Science, Madison, 7: 216-9, 1967.

FALCONER, D.S. Introduction to quantitative genetics. New York, The Ronald Press, 1964. $365 p$.

FITCH, B. Com oil. Joumal of the American Oil Chemists Society, Illinois, 62 : 1524-7, 1985.

FUNDUIANU, D. \& MOGA, A. Genetic variability in the content and yield of oil in maize population. Analele Institutului de Cercetari pentry Cereali Si Plante Thenice, Bucarest, 45: 15-21, 1980.

GALAL, H.E.; ABD-ALLA, S.A.; KASSABY, Y.A. Effect of sample size on precision of the estimates of genetic variance in maize. II. Ear caracters. Egyptian Joumal of Genetics and $\mathrm{Cy}_{\mathbf{y}}$ tology, Giza, 6: 306-18, 1977.

GARDNER, C.O. An evaluation of effects of mass selection and seed irradiation with thermal neutrons on yield of com. Crop Science Madison, $1: 241-5,1961$. 
GARWOOD, D.L.; WEBER, E.J.; LAMBERT, R.J. ; ALEXANDER, D.E. Effect of different cytoplasm on oil fatty acids, plant height and ear height in maize (Zea mays, L). Crop. Science, Madison, 10. 39-41, 1970.

GERALDI, 1.O. Estimação de parâmetros genéticos de caracteres do pendão em milho (Zea mays, (L.) e perspectivas de melhoramento. Piracicaba, 1977, 103p. (Mestrado-Escola Superior de Agricultura "Luiz de Queiroz"/USP).

GERALDI, I.O.; VELLO, N.A.\& VENCOVSKY, R. Estimativas de parâmetros genéticos e fenotipicos e implicaçōes no melhoramento de populaçōes de capim gordura (Melinis minutiflora Beauv.). Relatório Cientifico do Departarnento e Instituto de Genética,ESALQ. Piracicaba,: 73-86, 1975.

GERALDI, I.O.; VENCOVSKI, R.; MIRANDA FILHO, J.B. Processo para estimação dos componentes de covariáncia entre caracteres avaliados com número diferentes de indivíduos por parcela. Relatório Cientifico do Departamento de Genética, ESALQ, Piracicaba,: 12 84-91, 1978.

GOODMAN, M.M. Estimates of genetic variance in adapted and exotic populations of maize. Crop Science. Madison, 5:87-90, 1965.

GLOVER, D.V. \& TOSELLO, G.A. Kemel characteristics protein quality and biological value of the sugary-2 mutation and its combination with opaque-2 in Zea mays $L$ In: ANNUAL MEETING , 65., Madison, 1973. Agronomy Abstracts. Davis, American Society of Agronomy, 1973. p.5.

GOMES, F.P. Curso de estatistica 6 ed. Piracicaba, Livraria Nobel, 1976. 430p.

GUPTA, D; KOVÁCS, I.; GÁSPAR, L. Protein quality traits and their relationships with yield and yield components of opaque-2 and analogous normal maize hybrids and inbred lines. Theoretical and Applied Genetics, Berlin, 45: 341-8, 1975. 
HALLAUER, A.R. Change in genetic variance for seven plant and ear traits after four cycles of reciprocal recurrent selection for yield in maize. lowa State Joumal of Science, Ames, 45:575-93, 1971.

HALLAUER, A.R. \& MIRANDA FILHO, J.B. Quantitative genetics in maize breeding. Ames,lowa State University, 1981. 468p.

HALLAUER, A.R. \& WRIGHT, J.A. Genetic variance in the open-pollinated variety of maize, lowa Ideal. Der Züctrter, Berlin, 37: 178-85, 1967.

HAWKE, J.C. \& STUMPF, P.K. Fat metabolism in higher plants; 27. Syntesis of long-chain fatty acids by preparations of Hordeum vulgare L and other Gramineae. Plant Physiology, Lancaster, 40:1023-32, 1965.

HOPKINS, C.G. Improvement in the chemical composition of the corn kemel. In: DUDLEY, J.W., ed. Seventy generations of selection for oil and protein in maize. Madison, Crop Science of American, 1974. p.1-29.

HOPKINS, C.G.; SMITH, L.H.; EAST, E.M. The structure of the com kemel and the composition of its different parts. In: DUDLEY, J.W. ed. Seventy generations of selection for oil and protein in maize. Madison, Crop Science Society of America, 1974. p.33-63.

INGLET, G.E. Com culture, processing, products. Westprot, The Avi Publishing, 1970. 369p.

JELLUM, M.D. Fatty acid composition of corn oil of parental inbreed and reciprocal crosses. The Jounal of Heredity, Washington, $57:$ 243-4, 1966.

JELLUM, M.D. Fatty acid composition of com oil as influenced by kernel position on ear. Crop Science, Madison, 7:593-5, 1967. 
JELLUM, M.D. Developmental changes in fatty acid composition of oil kernel fractions of com (Zea mays L.) Joumal American oil Chemists Societs, Chicago, 47 : 245-8, 1970.

JELLUM, M.D. Registration of high stearic acid maize GE 180 germplasm. Crop Science, Madison, 24: 829-30, 1984.

JELLUM, M.D. \& MARION, J.E. Factors affecting oil content and oil composition of corn (Zea mays L.) grain. Crop Science. Madison, 6:41-2, 1966.

JELLUM, M.D. \& WIDSTROM, N.W. Inheritance of stearic acid in germ oil of the maize kernel. The Journal of Heredity, Washington, 74: 383-4, 1983.

JELLUM, M.D. \& WIDSTROM, N.W. Location of genes controlling oleic and linoleic acids in maize oil. Maize Genetics Cooperation. Newsletter, Urbana, 58: 88, 1984.

JELLUM, M.D.; HELM, J.L;; FERGASON, V.L.; ZUBER, M.S. Fatty acid composition of oil from normal and high amylase backcross strains of corn. Crop Science, Madison, 9. 746-9, 1969.

KEMPTHORNE, O. An introduction to genetic statistics. 3 ed. New York, John Wiley, 1966. $545 p$.

KHERA, A.S.; SINGH, H. ; DHIILON, B.S. Genetic architecture of a heterotic cross between two populations of maize. Theoretical and Applied Genetics, Berlin, 69. 259-61, 1985.

KIESSELBACH, T.A. The structure and reproduction of corn. Lincoln, Nebrasca Agricultural Experimental Station Research,1949. 96p. (Bulletin, 161).

KINOSHITA, K. \& PATERNIANI, E. Proporçăo endosperma/embrião e o seu efeito sobre o teor de óleo no milho Centralmex. Relatớrio Cientifico do Departamento de Genética, ESALQPiracicaba, 7: 68-73, 1973a.

KINOSHITA, K. \& PATERNIANI, E. Seleção para alto teor de óleo no milho "Centralmex". Relaúrio Cientifico do Departamento de Genética, ESALQ,Piracicaba, 7:62-7, 1973b. 
LAMBERT, R.J.; ALEXANDER, D.E.; ROGERS, R.C. Effect of kernel position on oil content in com (Zea mays L). Crop Science, Madison, 7. 143-4, 1967.

LENG, E.R. Predicted and actual responses during longterm selection for chemical composition in maize. Euphytica, Wageningen, 10: 368-78, 1961.

LENG, E.R. Changes in weight, germ ratio, and oil content during kernel development in high oil com (Zea mays L). Crop Science, Madison, 7: 333-4, 1967.

LENG, E.R. Results of long term selection for chemical composition in maize and their significance in evaluating breeding systems. In: DUDLEY, J.W. ed. Seventy generations of selection for oil and protein in maize. Madison, Crop Science Society of América, 1974. p.149-72.

LIMA, M. \& PATERNIANI, E. Estimativas de parâmetros genéticos e fenotípicos em progênies de meios irmãos (Zea mays L.) ESALQVD-2 MIHSII e suas implica̧̧ões com o melhoramento. Relatório Cientifico do Departamento de Instituto de Genética, ESALQ, Piracicaba, 11: 84-9, 1977.

LINDSEY, M.D.; LONQUIST, J.H.; GARDNER, C.O. Estimates of genetic variance in open-pollinated varieties of cornbelt com. Crop Science, Madison, 2 : 105-8, 1962.

MARQUES, J.R.B. Seleção recorrente com endogamia em duas populaçōes de milho (Zea mays L). Piracicaba, 1988. 145p. (Mestrado - Escola Superior de Agricultura "Luiz de Quei$\mathrm{roz}^{n} /$ USP).

MARQUEZ-SANCHEZ, F. \& HALLAUER, A.R. Influence of sample size on the estimation of genetic variance in a synthetic variety of maize. II. Plant and ear characters. lowa State Jounal of Science, Ames 44: 423-36, 1970. 
MARTINIELLO, P.; LORENZONI, C.; STANCA, A.M.; MAGGIORE, T.; GENTINETTA, E. ; SALAMINI, F. Seed quality differences between normal floury-2 and opaque-2 maize inbreds. Euphytica, Wageningen, 27: 411-7, 1978.

MARTINS, C.S. Potencial genético de linhagens e híbridos de duas populações de milho (Zea mays L.) braquítico. Piracicaba, 1986., 135p. (Mestrado-Escola Superior de Agriculura "Luiz de Queiroz"/USP).

MAZZARI, M.R. \& SIQUEIRA, F.A.R. Composiçáo quimica e aminogramas de cultivares de miIho em melhoramento genético. Rio de Janeiro, EMBRAPA-CTAA, 1982. 14p.

MEIRA, J.L. Produção de espigas e teores de proteína, lisina e óleo em progenitores e híbridos de milho Zea mays L. opaco-2. Viçosa, 1975. 44p. (Mestrado - Universidade Federal de Vi९osa).

MENDES, D.D. Estudo quimico comparativo das variedades de milho cultivadas em diversas regióes do pals. Rio de Janeiro, EMBRAPA-CTAA, 1972. 5p. (EMBRAPA-CTAA Boletim Técnico, 4).

MILLER, P.A. \& BRIMHALL, B. Factors influencing the oil and protein content of corn grain. Agronomy Joumal, Madison, 43:305-11, 1951.

MILLER, R.L;; DUDLEY, J.W.; ALEXANDER, D.E. High intensity selection for percent oil in com. Crop Science, Madison, 21: 433-7, 1981.

MIRANDA, P.; RUSCHEL, R.; PATERNIANI, E. Avaliação de famílias de meios-imãos no milho (Zea mays, L) Centralmex, para a produçāo de gráos e óleo. Recife, Instituto de Pesquisa Agronômico, 1976. 37p. (IPA. Boletim Técnico, 76).

MIRANDA FILHO, J.B.; VENCOVSKY, R.; PATERNIANI, E. Variância genética aditiva da produção de grãos em dois compostos de milho e suas implicações no melhoramento. Relatớrio Cientiffico do Departamento de Genética, ESALQ, Piracicaba, 6:67-73, 1972. 
MISEVIC, D. \& ALEXANDER, D.E. Twenty-four cycles of phenotypic recurrent selection for percent oil in maize. I Per se and testcross performance. Crop Science, Madison, 29. 320-4, 1989.

MOLL, R.H. \& ROBINSON. Quantitative genetics in investigations of yield of maize. Der Züctr ter, Berlin, 37: 191-9, 1967.

MORENO-GONZALEZ, J.; DUDLEY, J.W.; LAMBERT, R.J. A design III. Study of linkage disequilibrium for percent oil in maize. Crop Science, Madison, 15: 840-3, 1975.

MOTA, M.G. Comportamento de progênies de meios-irmãos e $S_{1}$ na variedade de milho Centralmex. Piracicaba, 1974. 73p. (Mestrado-Escola Superior de Agricultura "Luiz de Queiroz"/USP).

MURTY, G.S. \& ROY, N.N. Study of the indian collection of maize varieties with special reference to the relationship between yield and other characters. Indian Joumal of Genetics and Plant Breeding. New Delhi, 17: 73-89, 1957.

NASPOLINI FILHO, V. Variabilidade fenotipica e estabilidade em híbridos simples, híbridos duplos, variedades e compostos de milho (Zea mays L.). Piracicaba, 1975, 68p. (Mestrado Escola Superior de Agriculura "Luiz de Queiroz"/USP).

NILSSON, J.L.G.; REDALEIN, E.; NILSSON, I.M.; FOLKES, K. On the protection against infraction by corn oil. Acta Chemica Scandinavica, Copenhagen, 2297-105, 1968.

OBILANA, A.T. \& HALLAUER, A.R. Estimation of variability of quantitative traits in BSSS by using unselected maize lines. Crop Scionco. Madison, 14: 99-103, 1974.

OBILANA, A.T. \& HALLAUER, A.R. Comparison of estimates of genetic variability in lowa Stiff Stalk Synthetic of maize. Maydica, Bergamo, 22 159-72, 1977. 
OBILANA, A.T.; HALLAUER, A.R.; SMITH, O.S. Estimated genetic variability in a maize interpopulation. The Joumal of Heredity, Washington, 70. 127-32, 1979.

PAL, S.S.; KHEHRA, A.S.; DHILLON, B.S. Genetic analysis of the selection advance in a maize population. Maydica, Bergamo, 31:153-62, 1986.

PAMIN, K.; CAMPTON, W.A.; WALKER, C.E.; ALEXANDER, D.E. Genetic variation and selection response for oil composition in corn. Crop Science, Madison, 26 279-82, 1986.

PATERNIANI, E. Selection among and within half-sib families in a brazilian population of maize (Zea mays L.). Crop Science. Madison, 7: 212-6, 1967.

PATERNIANI, E. Relação entre o tamanho relativo do embriâo do milho avaliado visualmente e o teor de óleo. Relatório Cientifico do Departamento de Genética,ESALQ, Piracicaba, 6. 8690, 1972.

PATERNIANI, E. Origem e comportamento do milho Piranão. Relatório Cientifico do Departa mento de Genética, ESALQ, Piracicaba, 12 : 148-60, 1973.

PATERNIANI, E.; CASTRO, E.M.; RISSI, R. Competição entre populaçōes de milho normais e braquíticas. Relatório Cientifico do Departamento e Instituto de Genética,ESALQ, Piracicaba, 16: 15-24, 1982.

PATERNIANI, E.; ZINSLY, J.R.; MIRANDA FILHO, J.B. Populaçōes melhoradas de milho obtidas pelo Instituto de Genética. Relabrio Cientifico do Departamento de Genética/ESALQ. Piracicaba, 11: 108-14, 1977.

PLEWA, M.J. Isolation of chemical mutagen induced oil content mutants of maize. Maize Genetics Cooperation News Letter, Urbana, 53: 93-6, 1979. 
PONELEIT, C.G. \& ALEXANDER, D.E. Inheritance of linoleic and oleic acids in maize. Science, New York, 147: 1585-6, 1965.

PONELEIT, C.G. \& BAUMAN, L.F. Dialel analyses of fatty acids in com Zea mays L oil. Crop Science, Madison, 10. 338-41, 1970.

QUACKENBUSH, F.W. Corn oil quantity and physiological effects. In: HYBRID CORN INDUSTRY RESEARCH CONFERENCE, 16.,Chicago, 1961. Proceedings Chicago, American Seed Trade Association, 1961. p.27-32.

QUEIROZ, M.A. Correlaçōes genéticas e fenotipicas em progênies de meios irmãos em milho (Zea mays L) e suas implicaçōes no melhoramento. Piracicaba, 1969. 71p. (Mestrado - Escola Superior de Agricultura "Luiz de Queiroz"/USP).

RAMALHO, M.A.P. Eficiência relativa de alguns processos de seleção intrapopulacional no miIho baseados em famílias não endogamas. Piracicaba, 1977. 122p. (Doutorado - Escola Superior de Agriculura "Luiz de Queiroz"/USP).

RISSI, R. Estimação de parâmetros genéticos em duas subpopulaçōes da variedade de milho (Zea mays L) Piranão. Piracicaba, 1980. 87p.(Mestrado-Escola Superior de Agricultura "Luiz de Queiroz"/USP).

ROBINSON, H.F.; COMSTOCK, R.E.; HARVEY, P.H. Genotypic and phenotypic correlations in corn and their implications in selection. Agronomy Joumal, Madison, 43: 282-7, 1951.

ROCHE, I.A. de la; ALEXANDER, D.E.; WEBER, E.J. Inheritance of oleic and linoleic acids in Zea mays L. Crop Science, Madison, 11: 856-9, 1971a.

ROCHE, I.A. de la; WEBER, E.J.; ALEXANDER, D.E. Genetic aspects of triglyceride structure in maize. Crop Science, Madison, 11: 871-4, 1971 b.

ROHATGI, V.K. An introduction to probability theory and mathematical statistias New York, Jonh Wiley, 1976. 684p. 
ROUNDY, T.E. Effects of the sugary-2 endosperm mutant on kernel characteristics oil, protein and lysine in Zea mays L. Dissertation. Abstracts International, B, Lafayette, 37: 1063-4, 1976.

RUSCHEL, R. Selection for oil and relationships among oil protein and lysine in an opaque-2 population of maize Zea mays L Lafayette, 1972. 61p. (PhD. - Purdue University).

RUSCHEL, R. \& BAUMAN, LT. Seleção para alto teor de óleo no grão numa população de milho opaco-2. Pesquisa Agropecaŕria Brasileira, Brasília, 8:239-44, 1973.

SAMPAIO, N.F. Propriedades genéticas e potencial para o melhoramento dos compostos de milho (Zea mays L) ESALQ-PB4 e ESALQ-PB5. Piracicaba, 1986. 105p. (Mestrado - Escola Superior de Agricultura "Luiz de Queiroz"/USP).

SANTOS, M.X. dos. Estudo do potencial genético de duas raças brasileiras de milho (Zea mays L) para fins de melhoramento. Piracicaba, 1985. 185p. (Doutorado - Escola Superior de Agricultura "Luiz de Queiroz"/USP).

SANTOS, M.X. \& NASPOLINI FILHO, V. Estimativas de parâmetros genéticos em tres ciclos de seleção entre e dentro da famílias de meios irmãos no milho (Zea mays L) Dentado Composto Nordeste. Revista Brasileira de Genética, Ribeirão Preto, 9:307-19, 1986.

SAS INSTITUTE. The nested procedure. In: SAS STAT user's guide: release. 6. 03.ed. Cary, 1988. p.667-74. 
SHADLEY, J.D. \& WEBER, D.F. Identification of a factor in maize that increases embryo fatty acid unsaturation by trissomic and B-A translocation analyses. Canadian Joumal of Genetics and Cytology, Ottawa, 22. 11-9, 1980.

SHADLEY, J. \& WEBER, D. Location of chromosomal regions controlling fatty acid composition of embryo oil in Zea mays L. Canadian Joumal Genetics and Cytology, Ottawa, 28: 260-5, 1986.

SINGH, B.B. \& HADLEY, H.H. Maternal control of oil syntesis in soybeans, Glycine max (L.) Merr. Crop Science, Madison, 8:622-5, 1968.

SNEDECOR, G.W. \& COCHRAN, W.G. Statistical methods Ames, The lowa State University, 1967. 593p.

SOARES FILHO, W.S. Caracterlsticas fenotipicas e genéticas das populações de milho (Zea mays L) braquítico Piranão VD-2B e Piranão VF-1B. Piracicaba, 1987. 185p. (Doutorado Escola Superior de Agricultura "Luiz de Queiroz"/USP).

SONG, T.M.; SUN, Z;; ALEXANDER, D.E. Selection for oil content and grain quality improvement in maize (Zea mays L). Acta Agricultural Universitatis Pekinensis, Pekin, 2251-6, 1986.

SOUZA JUNIOR. C.L Análise de cruzamentos dialélicos e predição de compostos de milho (Zea mays L.) braquítico. Piracicaba, 1981. 102p. (Mestrado-Escola Superior de Agricultura ,"Luiz de Queiroz"/USP).

SOUZA JUNIOR. C.L Variabilidade genética em milho (Zea mays L) e relações com seleção recorrente intra e interpopulacional. Piracicaba, 1983. 151p. (Doutorado-Escola Superior de Agricultura "Luiz de Queiroz"/USP). 
SOUZA JUNIOR, C.L. \& ZINSLY, J.R. Avaliação de variedades de milho (Zea mays L) braquítico-2 em cruzamentos dialélicos. Relatório Cientfico do Departamento de Genética ESALQ, Piracicaba, 15: 271-84, 1981.

SPRAGUE, G.F. \& BRIMHALL, B. Quantitative inheritance of oil in the corn kernel. Agronomy Joumal, Madison, 41:30-3, 1949.

SPRAGUE, G.F. \& BRIMHALL, B. Relative effectibeness of two systems of selection for oil content of the com kernel. Agronomy Joumal, Madison, 4283-8, 1950.

SPRAGUE, G.F.; MILLER, P.A.; BRIMHALL, B. Aditional studies of the relative effectiveness of two systems of selection for oil content of corn kernel. Agronomy Joumal, Madison, 44: 329$31,1952$.

SRIWATANAPONGSE, S. \& BAUMAN, LF. Oil content as a measure of seed quality in corn (Zea mays L.). Crop Science, Madison, 6:88, 1966.

STEEL, R.G.D. \& TORRIE, J.H. Principles and procedures of statistics New York, McGraw-Hill, 1960. 481p.

STUMPF, P.K. \& JAMES, A.T. The biosynthesis of long chain fatty acids by lettuce chloroplast preparations. Biochimica et Biophysica Acta, Amsterdan, 70: 30-2, 1963.

SUN, D.; GREGORE, P.; GROGAN, C.O. Inheritance of saturated fatty acids in maize. The Joumal of Heredity, Washington, 69:341-2, 1978.

TOLLENAAR, M. Sink-source relationships during reproductive development in maize. A review. Maydica Bergamo, 22 49-75, 1977. 
TOSELLO, G.A. Comparações entre populaçōes de milho (Zea mays L.) opaco e normal. Piracicaba, 1978. 80p. (Livre Docência - Escola Superior de Agricultura "Luiz de Queiroz"/USP).

TOSELLO, G.A. \& GERALDI, 1.O. Correlações genéticas e fenotípicas envolvendo caracteres da planta e da qualidade do grão na população ESALQ-VD opaco de milho. Relatório Cientffi$\infty$ do Departamento de Genética, ESALQ, Piracicaba, 14 :190-3, 1980 .

TOSELLO, G.A. \& GERALDI, I.O. Estimativas de parâmetros genéticos e fenotípicos para caracteres da planta e da qualidade do grão na população de milho ESALQ-VD opaco. Relatório Cientifico do Departamento de Genética,ESALQ, Piracicaba, 14: 183-90, 1980 b.

TSAFARIS, A.S. \& SCANDALIOS, J.G. Comparison of the glyoxysomes and the glyoxysomal enzymes in maize lines with high or low oil content. Plant Physiology, Lancaster, 71: 447-50, 1983a.

TSAFARIS, A.S. \& SCANDALLOS, J.G. Genetic analysis of isocitrate lyase enzyme activity levels in maize lines selected for high or low oil content Joumal of Heredity, Washington, 74: 70-4, 1983b.

VALOIS, A.C.C. \& MIRANDA FILHO, J.B. Estimação de componentes de variância na cultivar de milho Centralmex. Pesquisa Agropecuária Brasileira, Brasilia, 19:479-88, 1984.

VALVA, D.D'A. Heterose em hibrido intervarietal de milho (Zea mays $L$ ) $\mathrm{br}_{2} \mathrm{br}_{2}$ (Braquitico-2). Piracicaba, 1976. 96p. (Mestrado - Escola Asuperior de Agricultura "Luiz de Queiroz"/USP).

VARGAS, J.E.; MOLINA, J.D.; CERVANTES, T. Seleccion masal y parametros genéticos en la variedad de maiz ZAC 58. Agrociencia, Chapingo, 48. 93-105, 1982. 
VELLO, N.A. \& VENCOVSKY, R. Variâncias associadas às estimativas de variâncias genéticas e coeficientes de herdabilidade. Relatório Cientfico do Departamento de Genética,ESALQ, Piracicaba, 8: 238-48, 1974.

VENCOVSKY, R. Herança Quantitativa In: PATERNIANI, E. \& VIEGAS, G.P., ed. Melhoramento e produção de milho. Campinas, Fundação Cargill, 1987. p.137-209.

VENCOVSKY, R.; MIRANDA FILHO, J.B.; SOUZA JÚNIOR, C.L. Quantitative genetics and com breeding in Brazil. In: INTERNATIONAL CONFERENCE ON QUANTITATIVE GENETICS, 2., Raleigh, 1987. Proceedings. Sunderland, Sinawer Associates, 1988. p.465-77.

VÖRÖSBARANYI, I.F. Investigation of changes in fatty acid composition in inbred maize lines during the erliest period of plant development. Zhomik za Prirodne Nauke, Novisad, 60:53-92, 1981.

WEBER, E.J. Variation in com (Zea mays L.) for fatty acid composition of triglycerides and phospholipids. Biochemical Genetics, Urbana, 21: 1-13, 1983.

WEBER, E.J. \& ALEXANDER, D.E. Breeding for lipid composition in corn. Joumal American Oil Chemists Society, Chigado, 52 370-3, 1975.

WESTON, E.S. \& TODD, W.R. Textbook of biochemistry. 3 ed. New York, The Macmillan, 1963. 1423p.

MDSTROM, N.W. \& JELLUM, M.D. Cromossomal location of genes controlling oleic and linoleic acid composition in the grain oil for two maize inbreds. Crop Science, Madison, 24: 1113-5, 1984. 
WLLIAMS, J.C.; PENNY, LH.; SPRAGUE, G.F. Ful-sib and half-sib estimates of genetic variance in an open-pollinated variety of corn. Zea mays L Crop Science. Madison, 5, 125-9. 1965.

WOODWORTH, C.M. ; LENG, E.R.; JUGENHEIMER, R.W. Fifty generations of selection for protein and oil in com. In: DUDLEY, J.W., ed. Seventy generations of selection for oil and protein in maize. Madison, Crop Science Society of America, 1974. p.121-31.

ZANOTTO, M.D. Variabilidade genética e endogamia em duas populaçōes de milho (Zea mays, L) contrastantes para teor de óleo. Piracicaba, 1986. 62p. (Mestrado - Escola Superior de Agricultura "Luiz de Queiroz"/USP).

ZIMBACK, L. Estimaşâo de parâmetros genéticos e fenotípicos em uma variedade de milho dentado braquítico opaco (Zea mays L). Piracicaba, 1985. 169p. (Mestrado - Escola Superior de Agricultura "Luiz de Queiroz"(USP). 
T A B E L A 


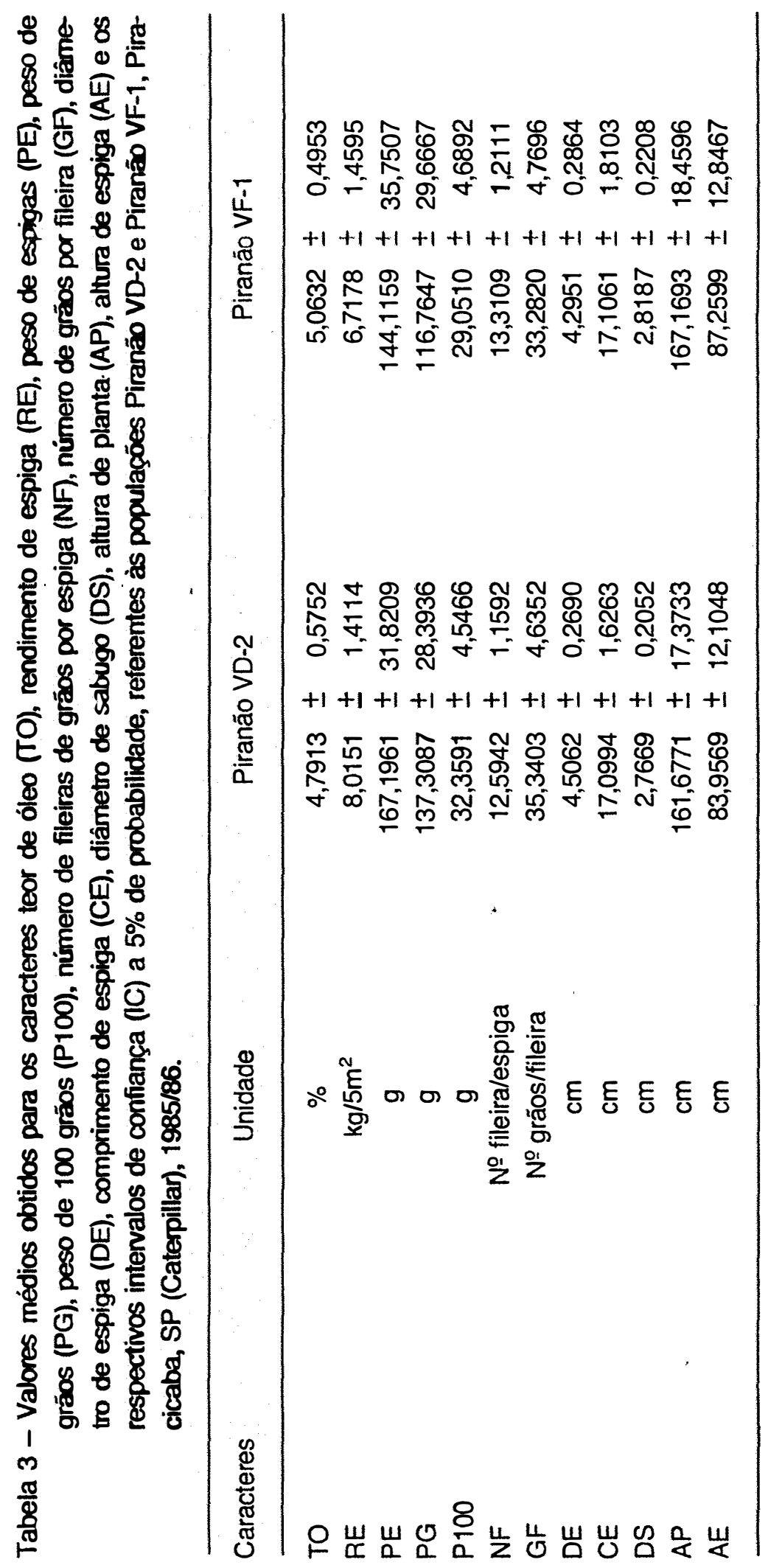




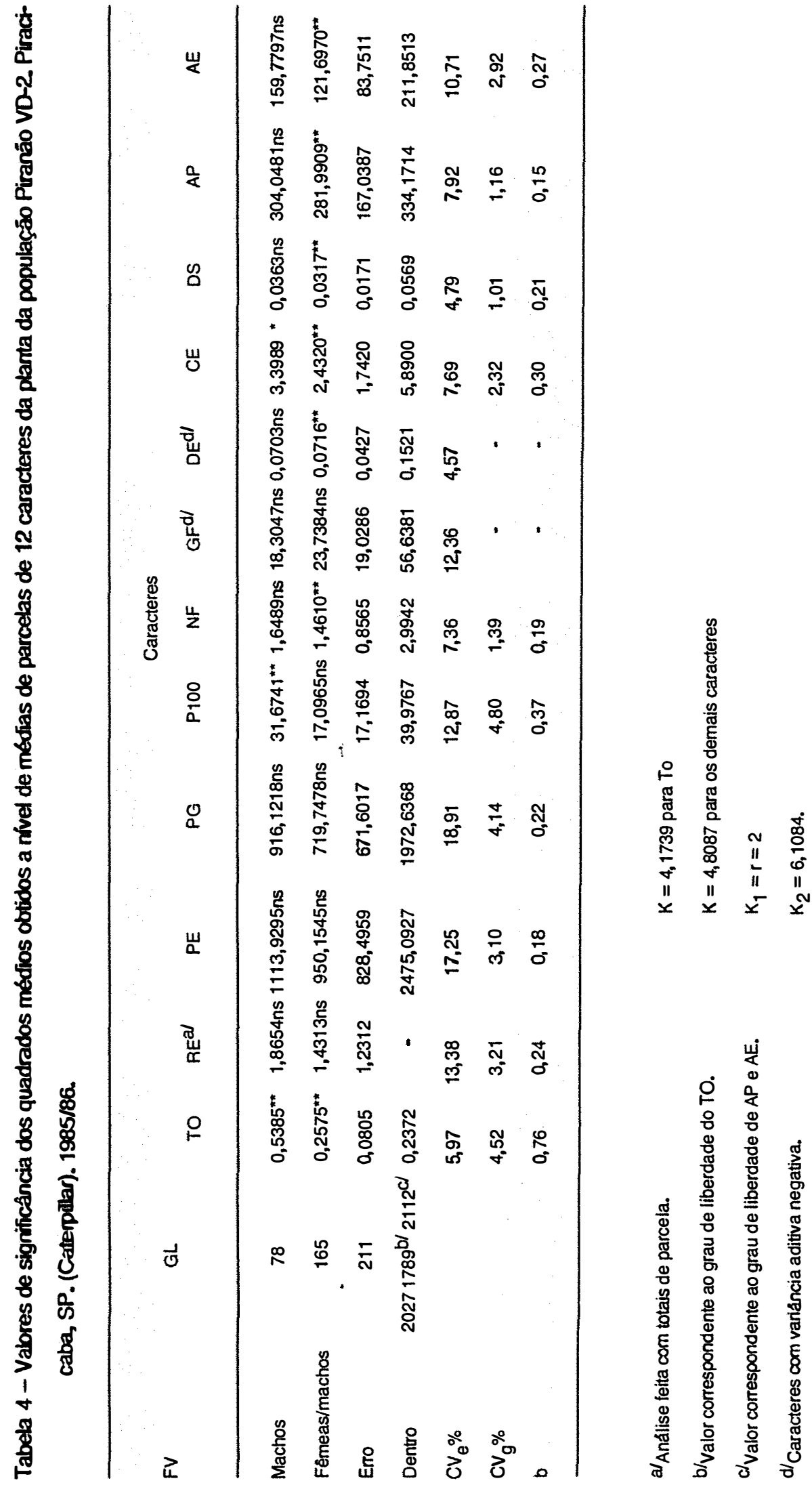




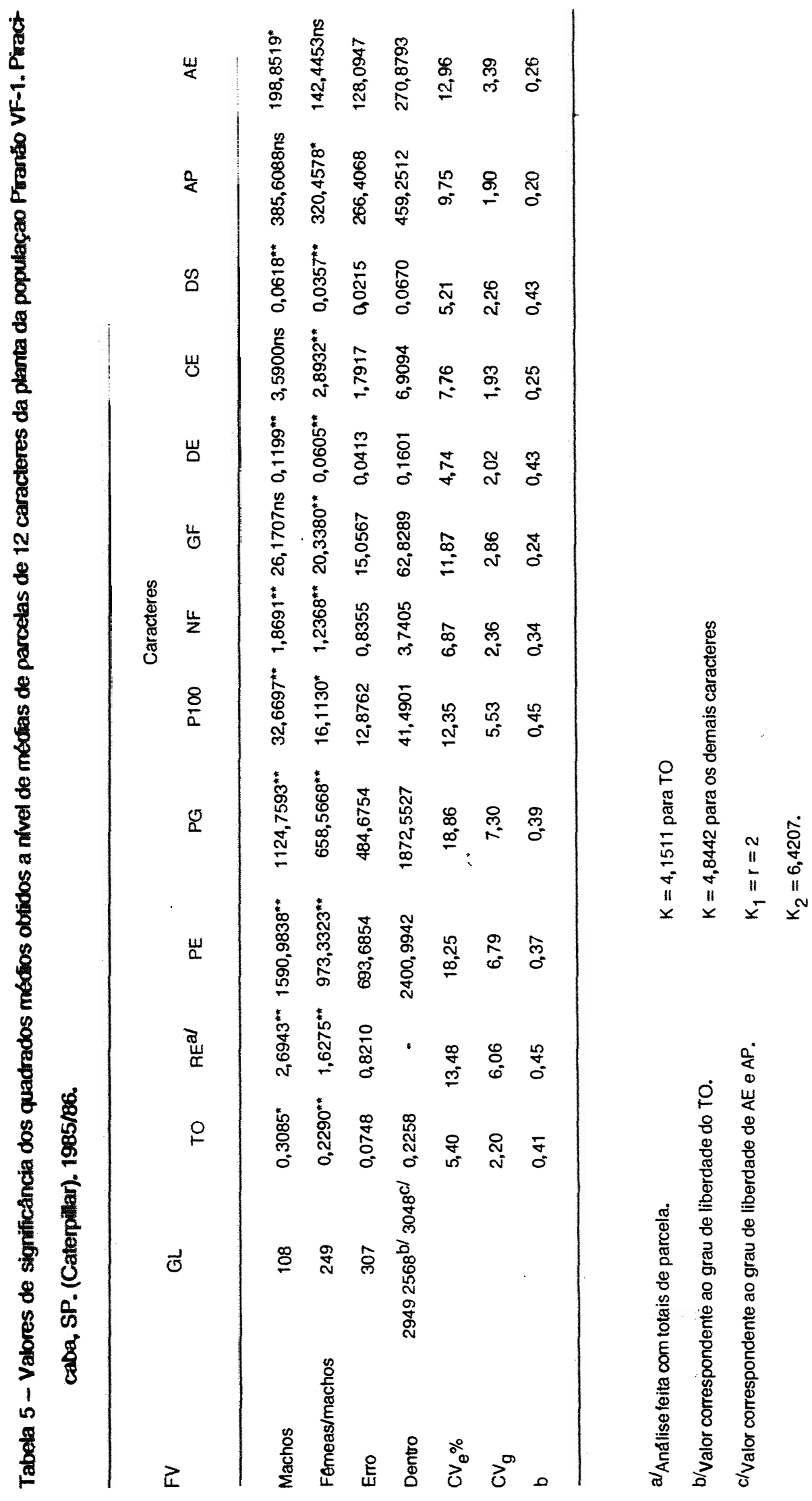




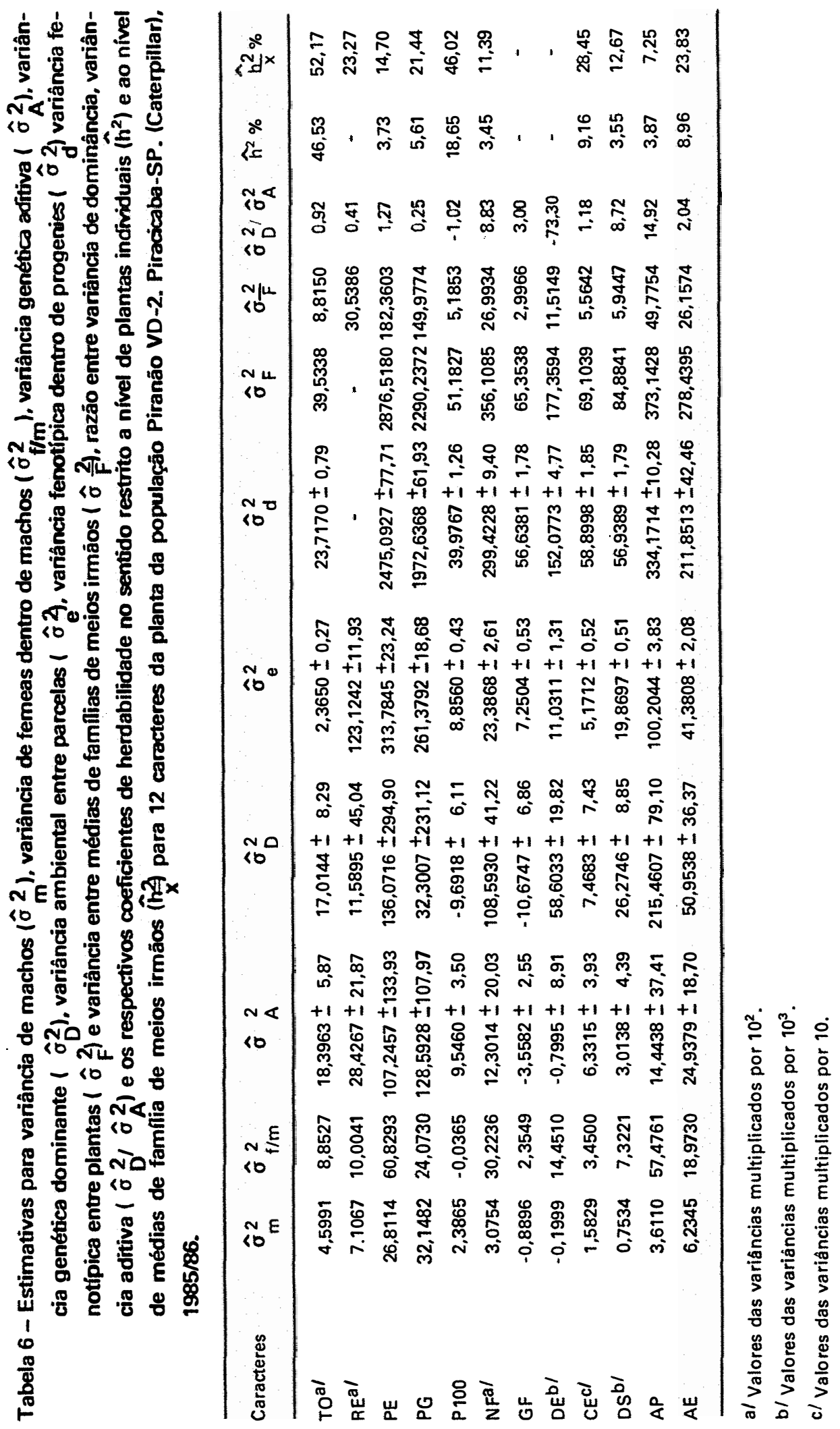




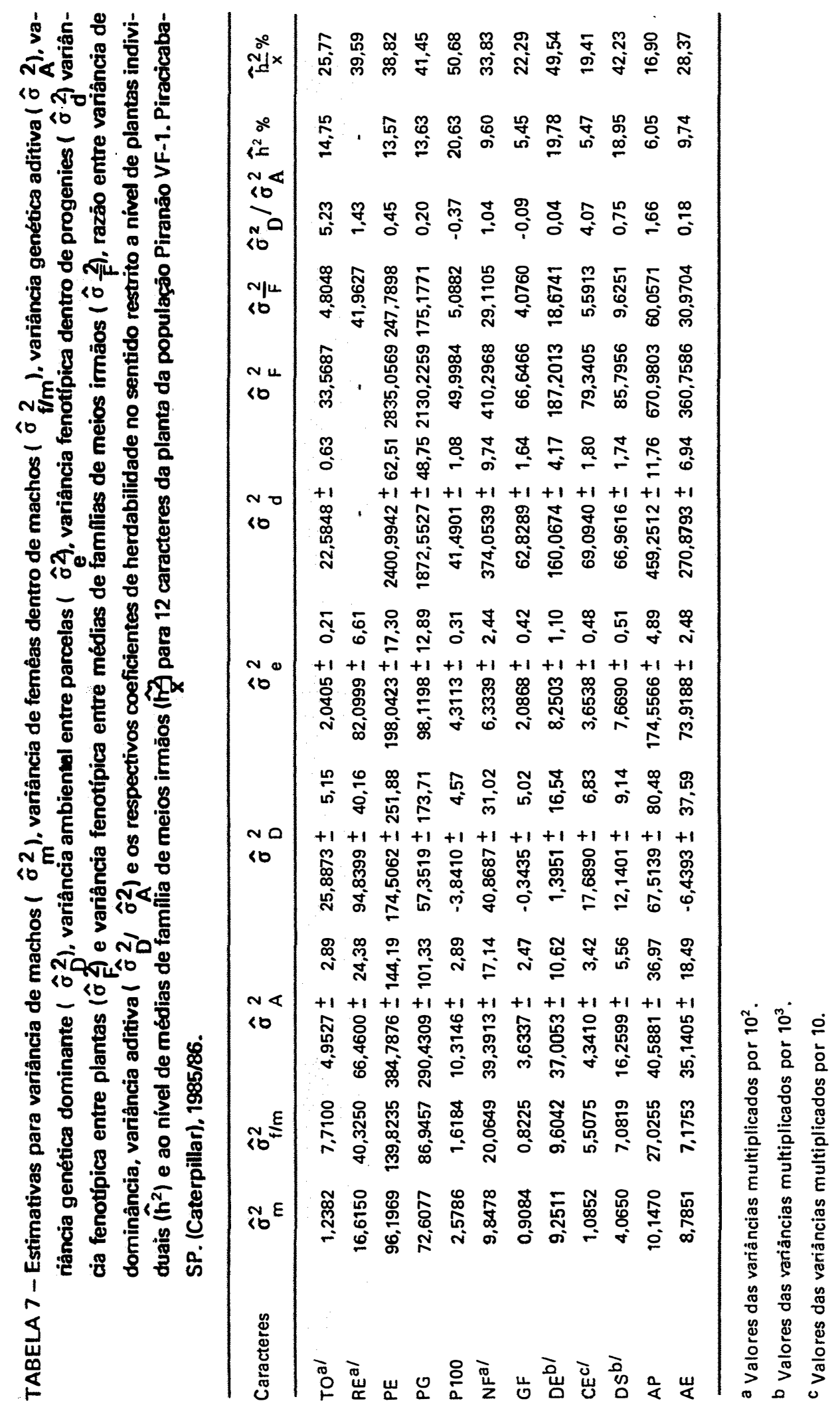


Tabela 8 - Estimativas dos progressas esperados $\left(G_{1}\right)$ por cicto, para 11 caracteres da planta das populaçōes Piranáo VD-2 e Piranáo VF-1, com seleçāo massal em um só sexo,considerandose a intensidade de seleção de 10\%. Piracicaba, SP. (Caterpillar), $1985 / 86$.

\begin{tabular}{|c|c|c|c|c|c|}
\hline \multirow[b]{2}{*}{ Caracteres } & \multirow[b]{2}{*}{ Unidade } & \multicolumn{2}{|c|}{ Piranão VD-2 } & \multicolumn{2}{|c|}{ Piranão VF-1 } \\
\hline & & $\mathrm{Gs}_{1} /$ ciclo & $\begin{array}{c}\text { Gs }_{1} / \text { ciclo } \\
(\%)\end{array}$ & Gs 1 /ciclo & $\begin{array}{c}\text { Gs }_{1} / \text { ciclo } \\
(\%)\end{array}$ \\
\hline TO & $\%$ & 0,2568 & 5,4081 & 0,0750 & 1,4799 \\
\hline PE & $g$ & 1,7552 & 1,0517 & 6,3432 & 4,3942 \\
\hline$P G$ & $g$ & 1,3586 & 1,7210 & 5,5233 & 4,7307 \\
\hline P100 & $g$ & 1,1712 & 3,6369 & 1.2804 & 4,4075 \\
\hline NF & № fileira/espiga & 0,0572 & 0,4550 & 0,1707 & 1,2832 \\
\hline GF & № grãos/fileira & - & - & 0,3907 & 1,1733 \\
\hline$D E$ & $\mathrm{~cm}$ & - & - & 0,0751 & 1,7502 \\
\hline CE & $\mathrm{cm}$ & 0,2114 & 1,2323 & 0,1353 & 0,7908 \\
\hline DS & $\mathrm{cm}$ & 0,0091 & 0,337 & 0,0487 & 1,7300 \\
\hline$A P$ & $\mathrm{~cm}$ & 0,6563 & 0,4020 & 1,3754 & 0,8219 \\
\hline$A E$ & $\mathrm{~cm}$ & 1,3118 & 1,5355 & 1,6239 & 1,8595 \\
\hline
\end{tabular}


Tabela 9 - Estimativas dos progressos esperados (Gs2) por ciclo, para 12 caracteres da planta das populaçoes Piranāo VD-2 e Piranão VF, com seleção entre famílias de meios imnāos, com sementes remanescentes, considerandose a intensidade de seleção de $20 \%$. Piracicaba, SP. (Caterpillar), 1985/86.

\begin{tabular}{|c|c|c|c|c|c|}
\hline \multirow[b]{2}{*}{ Caracteristicas } & \multirow[b]{2}{*}{ Unidade } & \multicolumn{2}{|c|}{ Piranão VD-2 } & \multicolumn{2}{|c|}{ Piranāo VF-1 } \\
\hline & & $\mathrm{Gs}_{2} /$ ciclo & $\begin{array}{c}\text { Gs}_{2} / \text { ciclo } \\
(\%)\end{array}$ & $\mathrm{Gs}_{2} /$ ciclo & $\begin{array}{c}\text { Gs}_{2} / \text { ciclo } \\
\text { (\%) }\end{array}$ \\
\hline TO & $\%$ & 0,2168 & 4,5657 & 0,0791 & 1,5608 \\
\hline RE & $\mathrm{kg} / 5 \mathrm{~m}^{2}$ & 0,1800 & 2,1711 & 0,3590 & 5,3412 \\
\hline PE & $g$ & 2,7792 & 1,6653 & 8,5543 & 5,9259 \\
\hline$P G$ & $\mathrm{~g}$ & 3,6746 & 2,6813 & 7,6791 & 6,5771 \\
\hline P100 & $g$ & 1,4670 & 4,5555 & 1,6002 & 5,5083 \\
\hline NF & № fileira/espiga & 0,0829 & 0,6594 & 0,2525 & 1,9206 \\
\hline GF & № grãos/fileira & - & - & 0,6299 & 1,8917 \\
\hline $\mathrm{DE}$ & $\mathrm{cm}$ & - & - & 0,0948 & 2,2093 \\
\hline CE & $\mathrm{cm}$ & 0,2970 & 1,7313 & 0,2032 & 1,1876 \\
\hline DS & $\mathrm{cm}$ & 0,0137 & 0,5024 & 0,0580 & 2,0603 \\
\hline AP & $\mathrm{cm}$ & 0,7164 & 0,4388 & 1,8328 & 1,0952 \\
\hline$A E$ & $\mathrm{~cm}$ & 1,7064 & 1,9974 & 2,2097 & 2,5302 \\
\hline
\end{tabular}




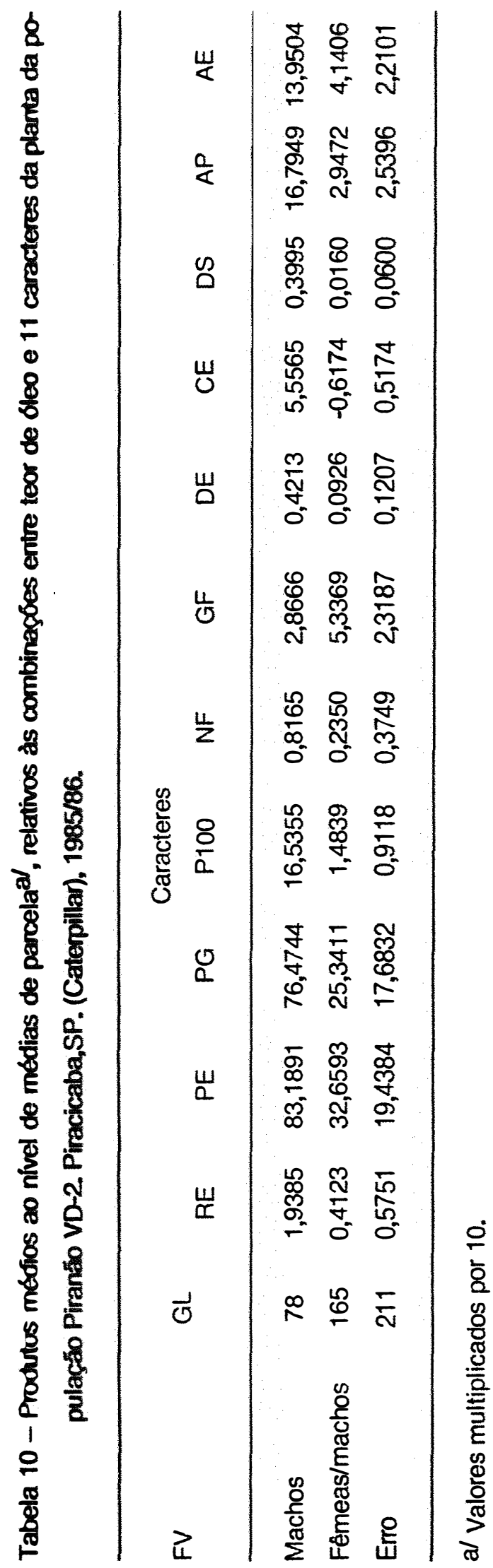




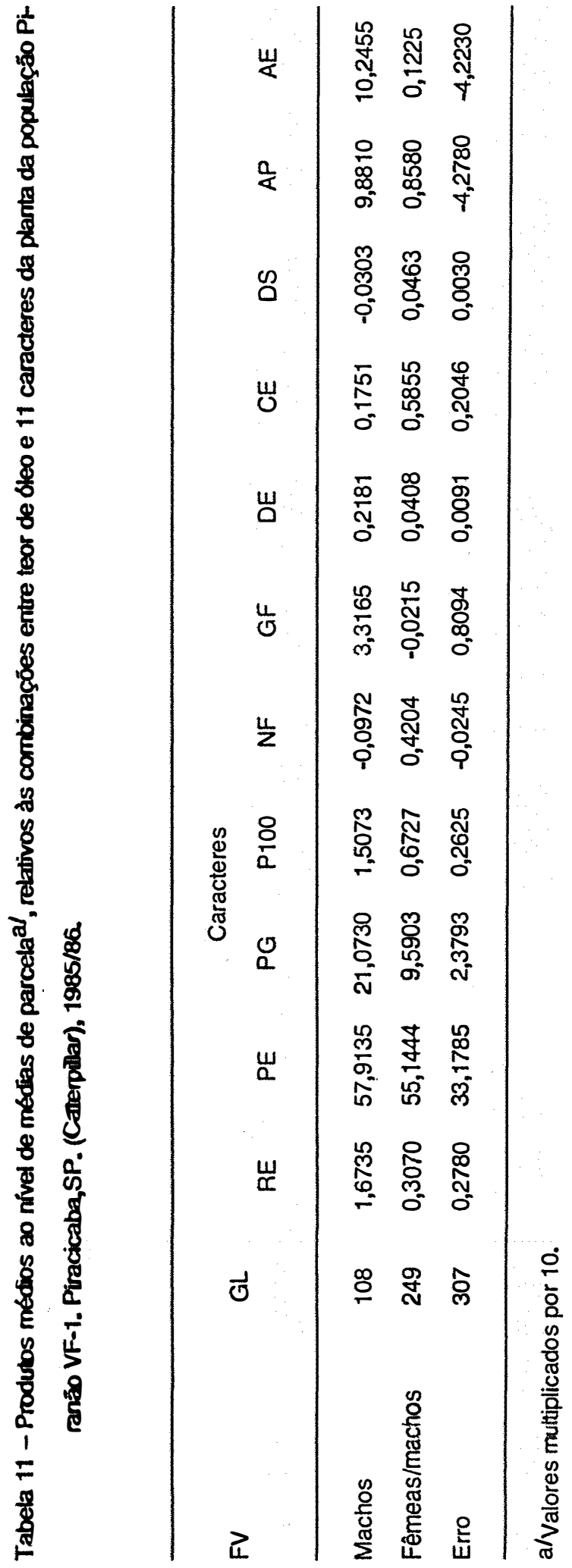




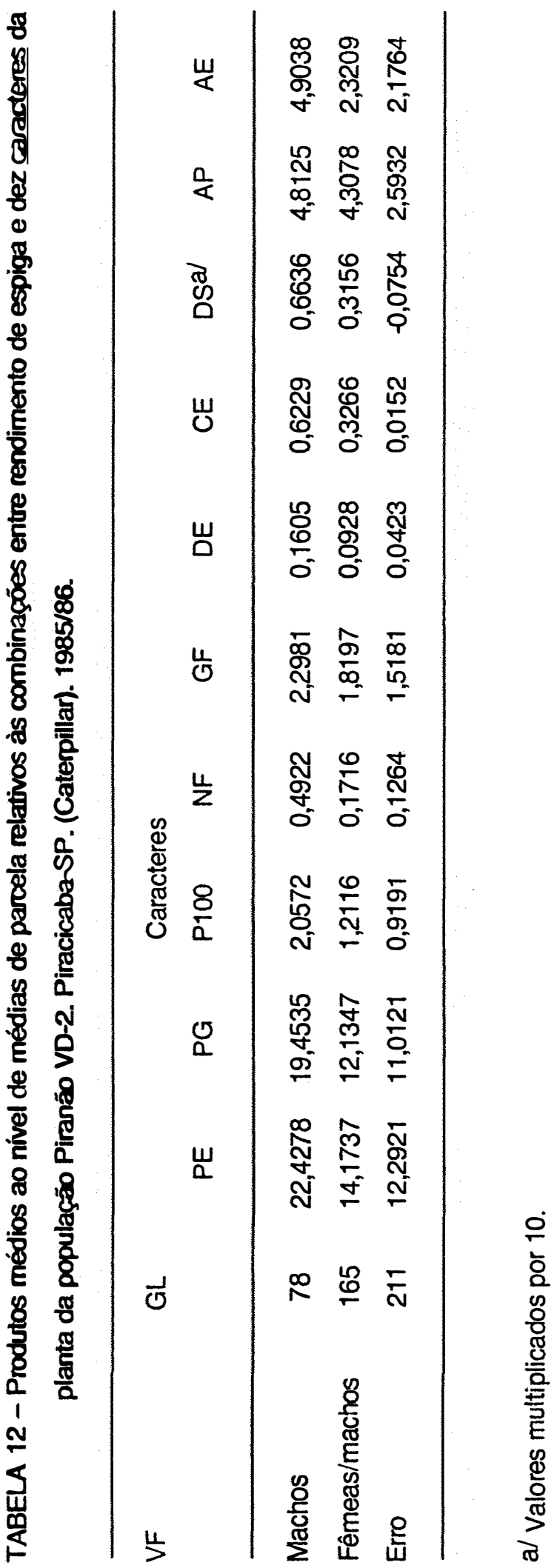




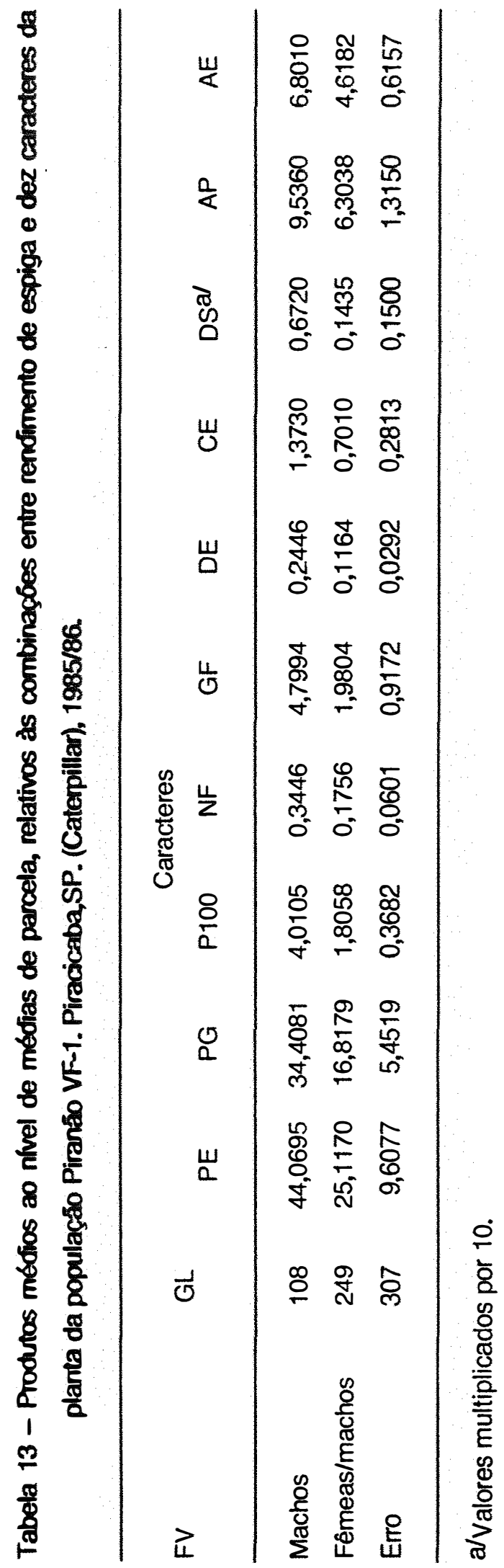




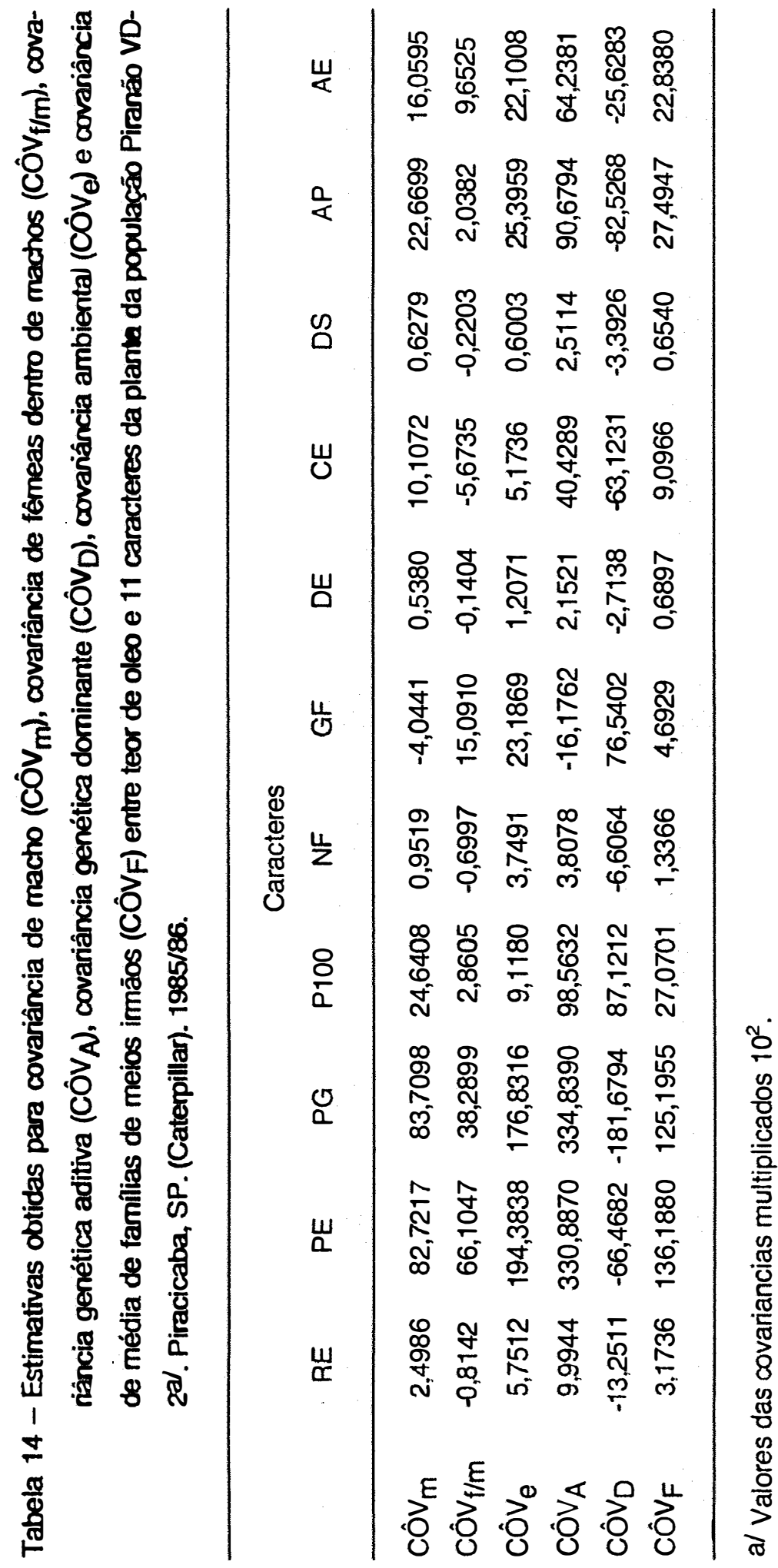




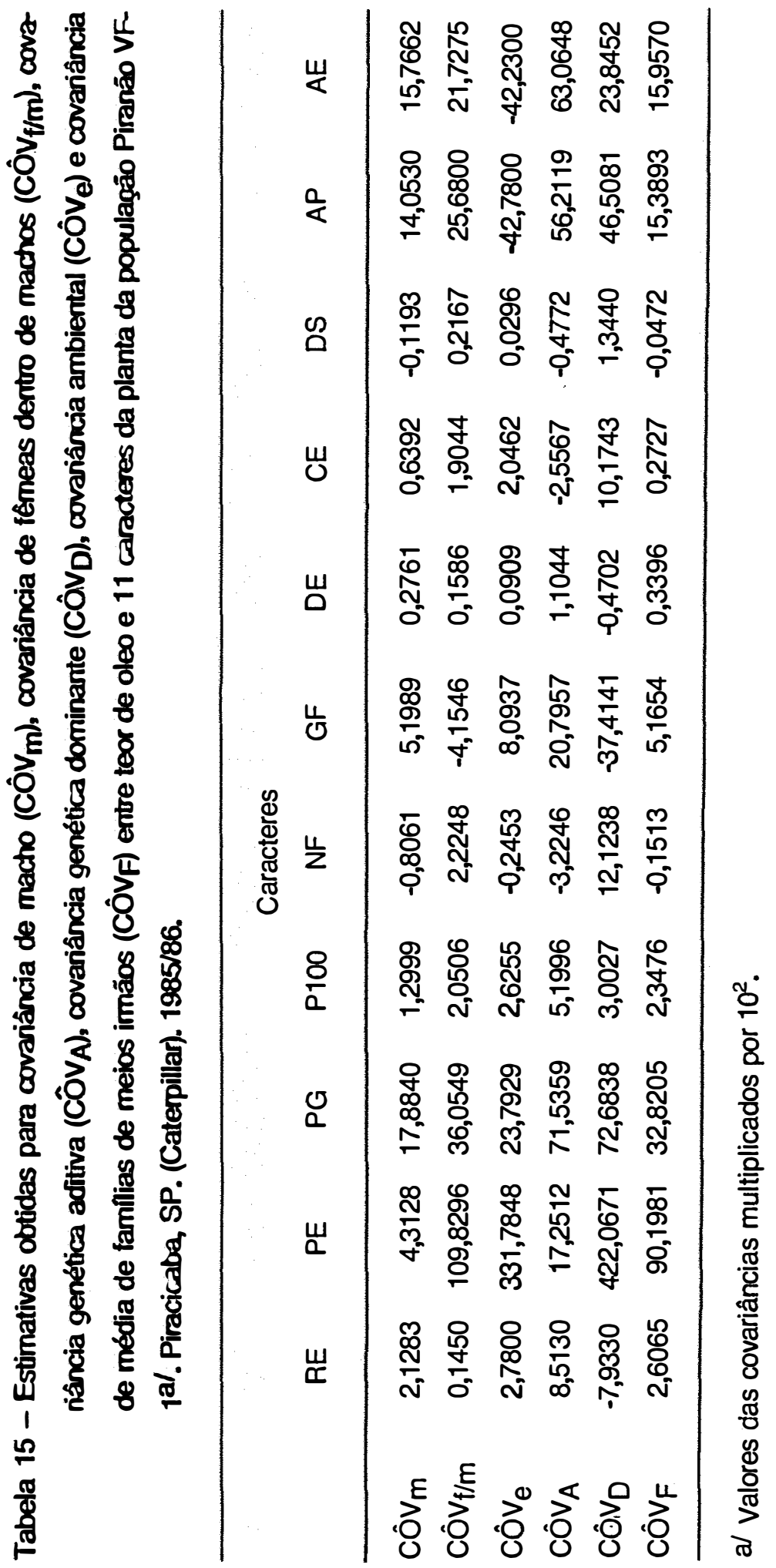




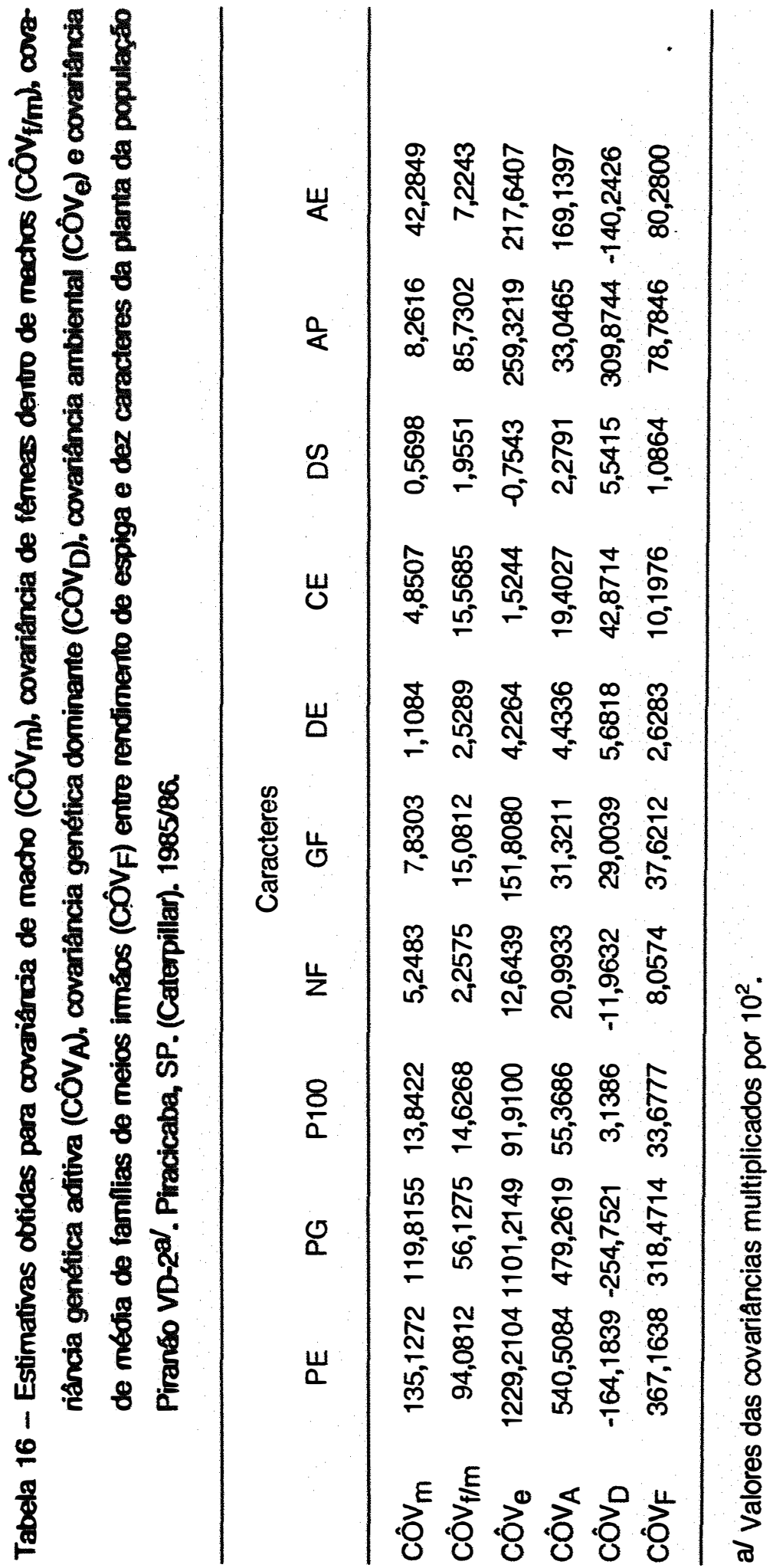




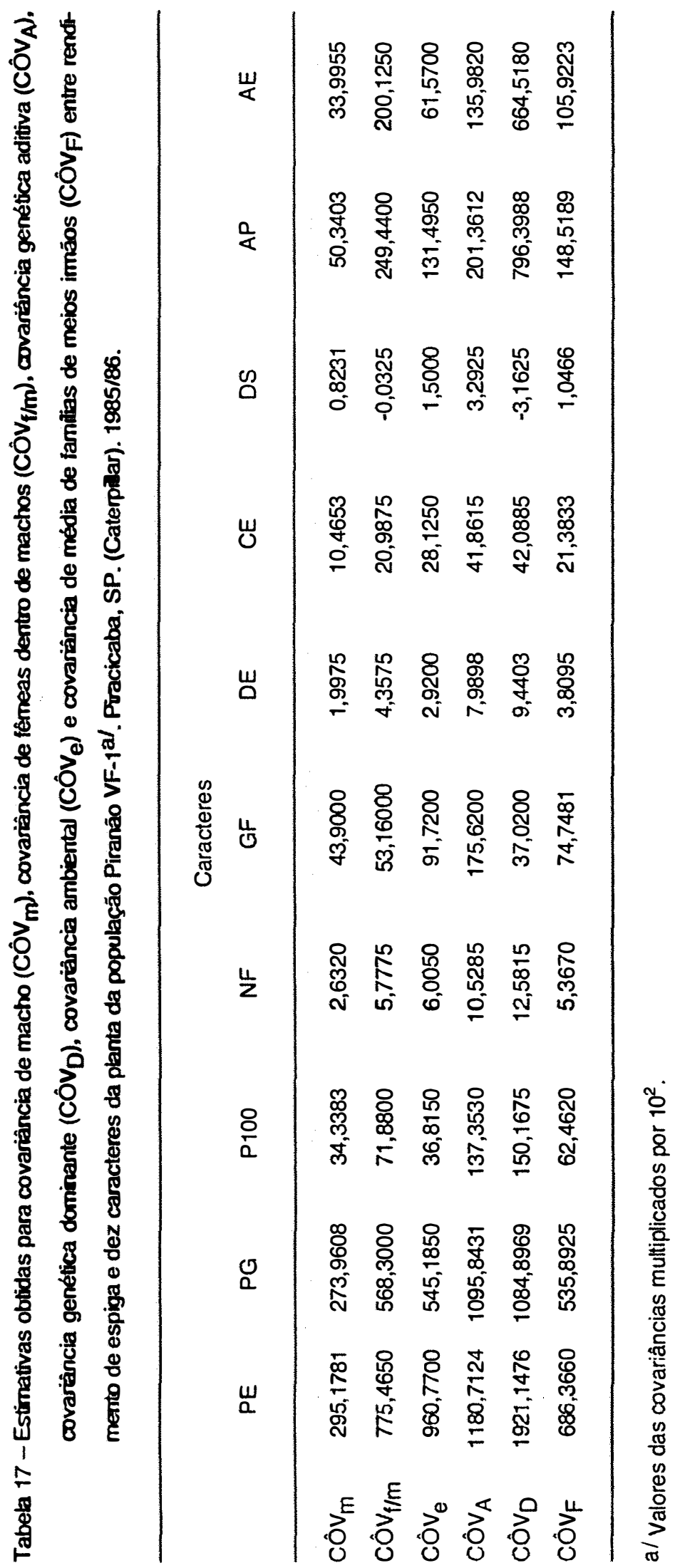


Tabela 18 - Estimativas de coeficientes de correlação entre rendimento de espiga e dez carac teres da planta das populaçóes Piranão VD-2 e Piranáo VF-1. Piracicaba, SP (Ca terpillar), 1985/86.

\begin{tabular}{lccccc}
\hline & \multicolumn{3}{c}{ Piranão VD-2 } & \multicolumn{2}{c}{ Piranão VF-1 } \\
Caracteres & $r_{A}$ & $r_{F}$ & $r_{A}$ & $r_{F}$ \\
\hline & & & & \\
PE & 0,9789 & 0,4920 & 0,7383 & 0,6731 \\
PG & 0,7927 & 0,4706 & 0,7888 & 0,6250 \\
P100 & 0,3361 & 0,2676 & 0,5246 & 0,4275 \\
NF & 1,1226 & 0,2806 & 0,2058 & 0,1536 \\
GF & - & 0,3933 & 1,1301 & 0,5715 \\
DE & - & 0,4432 & 0,5095 & 0,4303 \\
CE & 0,4573 & 0,2474 & 0,7794 & 0,4415 \\
DS & 0,7786 & 0,2550 & 0,3167 & 0,1647 \\
AP & 0,1631 & 0,2021 & 0,3877 & 0,2958 \\
AE & 0,6353 & 0,2840 & 0,2814 & 0,2938 \\
& & & & & \\
\hline
\end{tabular}


Tabela 19 - Estimativas de coeficientes de correlação entre teor de óleo e 11 caracteres da planta das populaçōes Piranåo VD-2 e Piranão VF-1. Piracicaba, SP (Caterpillar), 1985/86.

\begin{tabular}{lrrrrr}
\hline Caracteres & \multicolumn{2}{c}{ Piranão VD-2 } & \multicolumn{2}{c}{ Piranão VF-1 } \\
& r A & rF & r A & r F \\
\hline & & & & \\
RE & 0,4370 & 0,1934 & 0,4692 & 0,1836 \\
PE & 0,7449 & 0,3397 & 0,0395 & 0,2614 \\
PG & 0,6884 & 0,3443 & 0,1886 & 0,1131 \\
P100 & 0,7438 & 0,4004 & 0,0727 & 0,0475 \\
NF & 0,2531 & 0,0867 & $-0,2309$ & $-0,0128$ \\
GF & - & 0,0913 & 0,4902 & 0,1167 \\
DE & - & 0,2165 & 0,2580 & 0,1134 \\
CE & 1,1846 & 0,4107 & $-0,1744$ & 0,0166 \\
DS & 1,0666 & 0,2857 & $-0,1682$ & $-0,0219$ \\
AP & 0,5563 & 0,1313 & 0,3965 & 0,0906 \\
AE & 0,2999 & 0,1504 & 0,4780 & 0,1308 \\
\hline
\end{tabular}


Tabela 20 - Estimativas das respostas correlacionadas (Ry/x) por cicto, no teor de óleo, quando uma selec50 entre (20\%) progenies de meios imšos foi feita em 11 caracteres, da planta das populaçб̄es Pi̛año VD-2 e Piranáo VF-1. Piracicaba, SP (Caterpilar), 1985/86.

\begin{tabular}{|c|c|c|c|c|}
\hline \multirow{2}{*}{ Caracteres } & \multicolumn{2}{|c|}{ Piranão VD-2 } & \multicolumn{2}{|c|}{ Piranão VF-1 } \\
\hline & $\mathrm{R}_{\mathrm{TO} / \mathrm{x} / \text { ciclo }}$ & $\begin{array}{c}\mathrm{R}_{\mathrm{TO} / \mathrm{x} / \text { ciclo }} \\
(\%)\end{array}$ & $\mathrm{R}_{\mathrm{TO} / \mathrm{x} / \text { ciclo }}$ & $\begin{array}{c}\mathrm{R}_{\mathrm{TO} / \mathrm{x} / \text { ciclo }} \\
(\%)\end{array}$ \\
\hline $\mathrm{RE}$ & 0,0633 & 1,3331 & 0,0460 & 0,9077 \\
\hline PE & 0,0857 & 1,8048 & 0,0038 & 0,0750 \\
\hline$P G$ & 0,0957 & 2,0154 & 0,0189 & 0,3729 \\
\hline P100 & 0,1515 & 3,1905 & 0,0081 & 0,1598 \\
\hline NF & 0,0256 & 0,5391 & $-0,0209$ & $-0,4124$ \\
\hline GF & $-0,0327$ & $-0,6887$ & 0,0360 & 0,7103 \\
\hline$D E$ & 0,0702 & 1,4784 & 0,0283 & 0,5584 \\
\hline$C E$ & 0,1897 & 3,9950 & $-0,0120$ & $-0,2368$ \\
\hline DS & 0,1140 & 2,4008 & $-0,0170$ & $-0,3354$ \\
\hline AP & 0,0450 & 0,9477 & 0,0254 & 0,5012 \\
\hline$A E$ & 0,0440 & 0,9266 & 0,0397 & 0,7833 \\
\hline
\end{tabular}


Tabela 21 - Estimativas das respostas correlacionadas (Ry/x) por ciclo em 11 caracteristicas, quando uma seleçäo entre (20\%) progenies de meios imnáos foi feita no teor de óleo das plantas da população Piranáo VD-2 e Piranáo VF-1. Piracicaba, SP (Caterpillar), $1985 / 86$.

\begin{tabular}{|c|c|c|c|c|c|}
\hline \multirow{2}{*}{ Caracteres } & \multirow{2}{*}{ Unidade } & \multicolumn{2}{|c|}{ Piranão VD-2 } & \multicolumn{2}{|c|}{ Piranão VF-1 } \\
\hline & & $\mathrm{R}_{\mathrm{x} / \mathrm{TO} / \text { ciclo }}$ & $\begin{array}{c}\mathrm{R}_{\mathrm{X} / \mathrm{TO} / \text { ciclo }} \\
(\%)\end{array}$ & $\mathrm{R}_{\mathrm{x} / \mathrm{TO} / \text { ciclo }}$ & $\begin{array}{c}\mathrm{R}_{\mathrm{x}} / \mathrm{TO} / \text { ciclo } \\
(\%)\end{array}$ \\
\hline RE & $\mathrm{kg} / 5 \mathrm{~m}^{2}$ & 0,1178 & 1,4208 & 0,1359 & 2,0219 \\
\hline PE & g & 3,9001 & 2,3369 & 0,2754 & 0,1908 \\
\hline$P G$ & $g$ & 3,9467 & 2,8799 & 1,1421 & 0,9782 \\
\hline P100 & g & 1,1617 & 3,6074 & 0,0830 & 0,2857 \\
\hline NF & № fileiras/espiga & $-0,0449$ & $-0,3571$ & $-0,0515$ & $-0,3871$ \\
\hline GF & № grãos/fileira & $-0,1907$ & $-0,5405$ & 0,3320 & 0,9971 \\
\hline DE & $\mathrm{cm}$ & 0,0254 & 0,5617 & 0,0176 & 0,4102 \\
\hline CE & $\mathrm{cm}$ & 0,4765 & 2,7776 & $-0,0408$ & $-0,2385$ \\
\hline DS & $\mathrm{cm}$ & 0,0296 & 1,0854 & $-0,0076$ & $-0,2700$ \\
\hline$A P$ & $\mathrm{~cm}$ & 1,0688 & 0,6547 & 0,8974 & 0,5362 \\
\hline$A E$ & $\mathrm{~cm}$ & 0,7572 & 0,8863 & 1,0068 & 1,1529 \\
\hline
\end{tabular}


F I G U R A S 


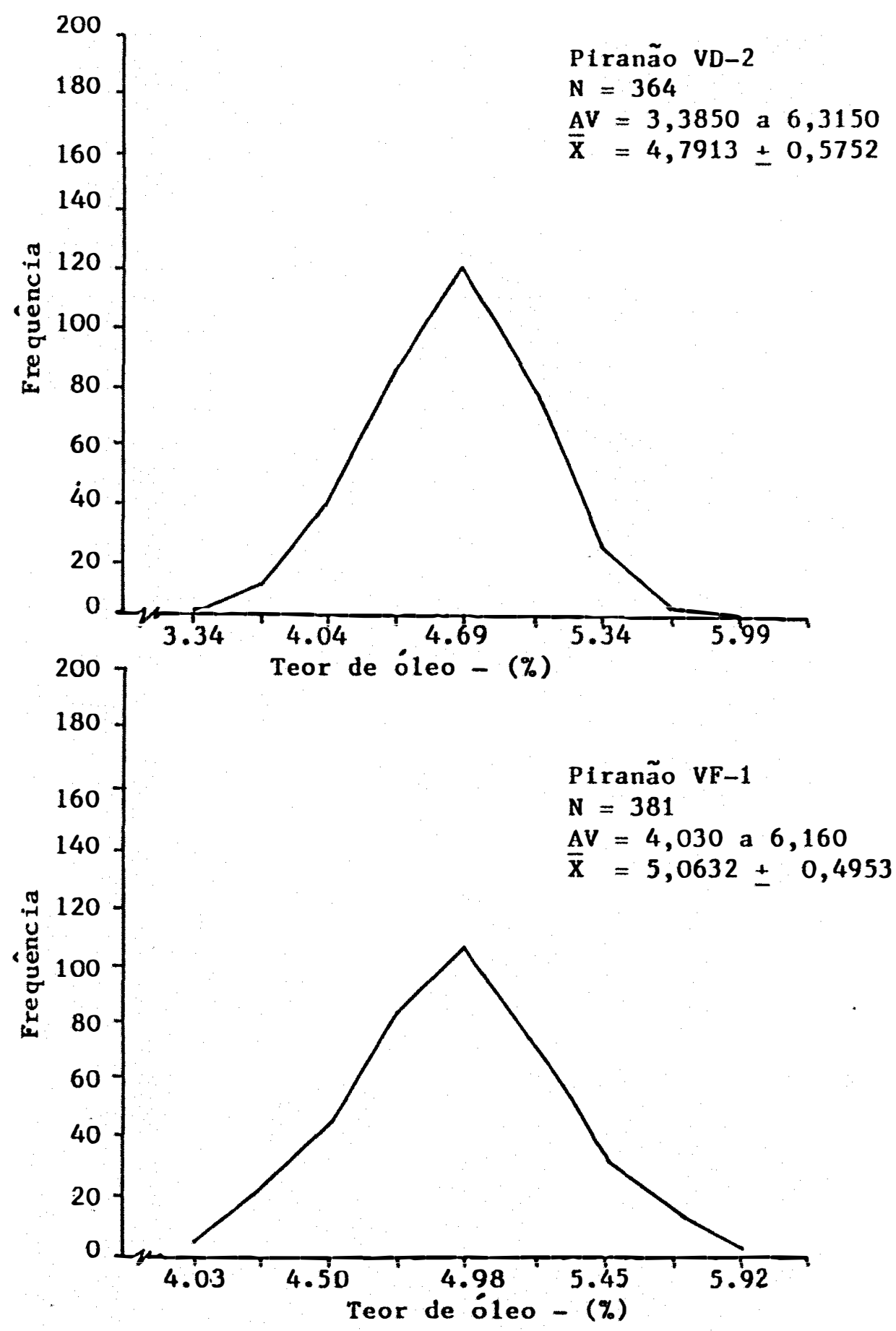

FIGURA 1 - Distribulção das médias para teor de óleo $(\%)$, referente as populações Piranão VD-2 e Piranão VF-1, destacando-se - numero de médías (N) e a amplitude de variação (AV) e a média geral $(\bar{X})$ com o respectivo intervalo de confiança (IC) a $5 \%$ de probabilidade. Piracicaba-SP. (Caterpillar). $1985 / 86$. 


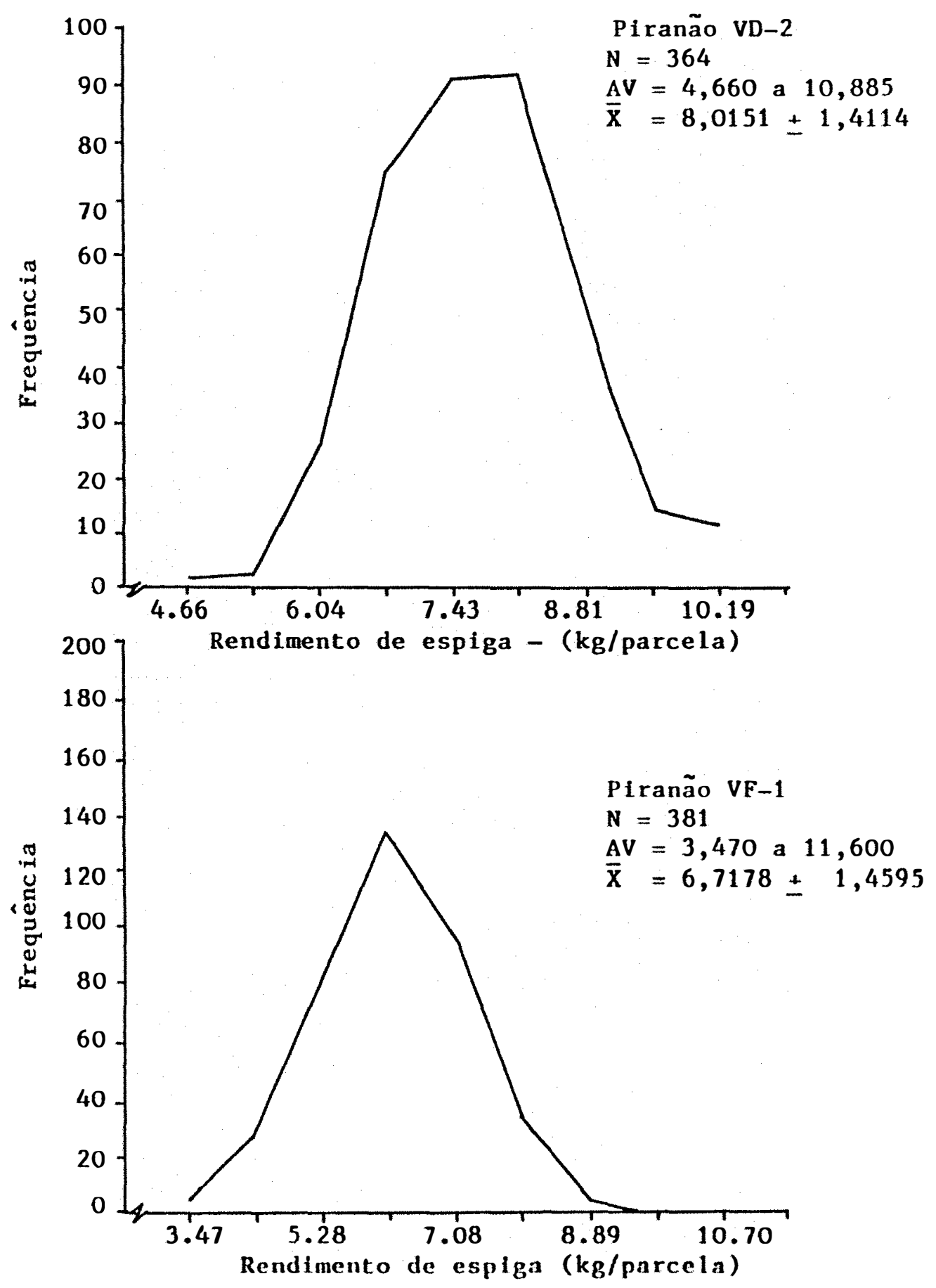

FIGURA 2 - Distribuição das médias para rendimento de espiga $\left(\mathrm{kg} / 5 \mathrm{~m}^{2}\right)$, referente as populações PIranão VD-2 e Plranão VF-1, destacando-se o numero de médias (N), a amplitude de variancia (AV) e a média geral $(\bar{X})$, com o respectivo intervalo de con fiança (IC) a $5 \%$ de probabilidade. Piracicaba-SP. (Caterpillar). $1985 / 86$. 


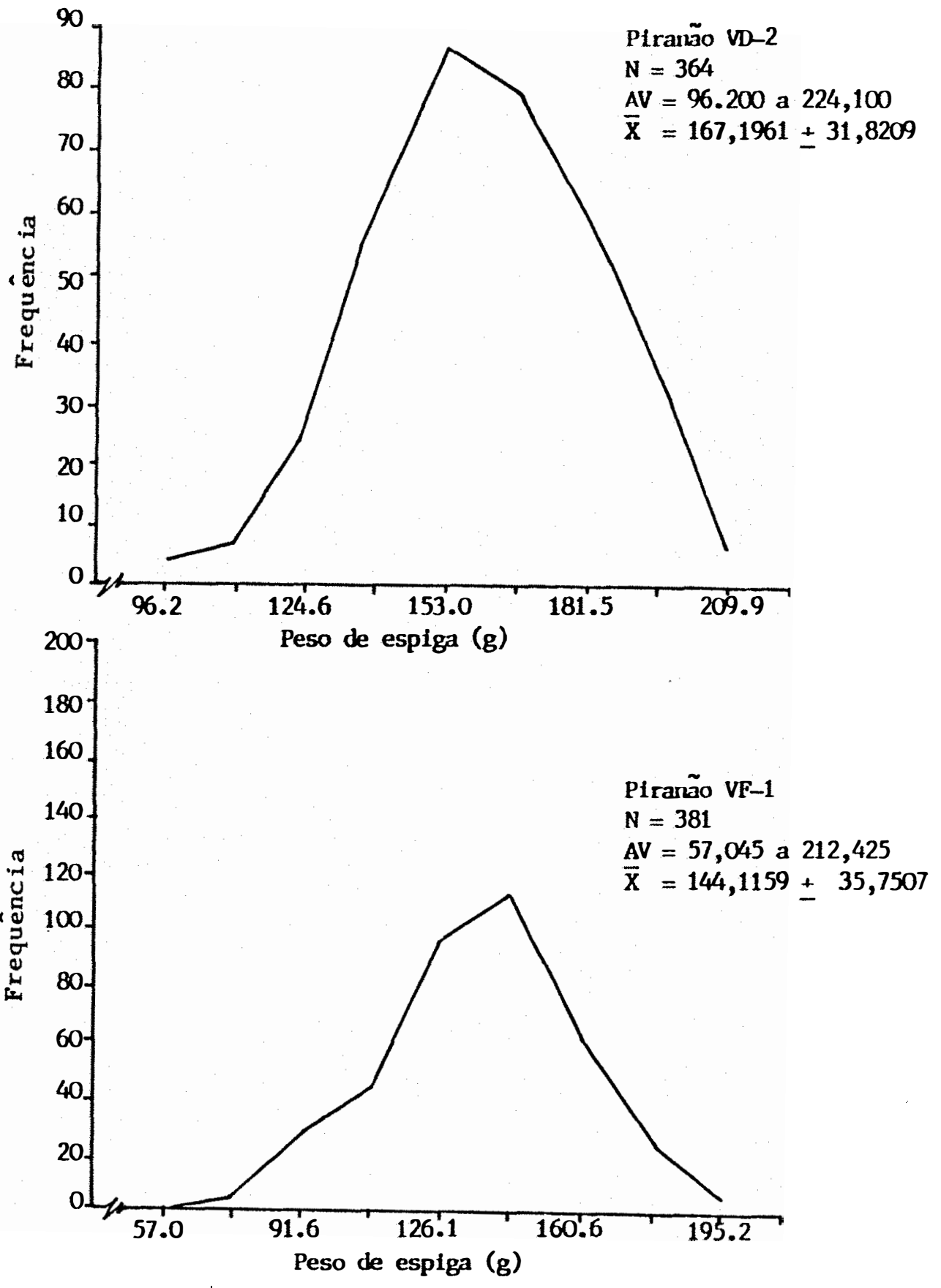

Figura 3 - Distribuịção das médias para peso de espigas (g), re ferente as populações Piranão VD-2 e Piranão VF-1, destacando-se o nume ro de médias (N), a amplitude de variação (AV) e a média geral $(\bar{X})$ com o respectivo intervalo de confiança (IC) a $5 \%$ de probabilidade. Piracicaba,SP. (Caterpillar). 1985/86. 


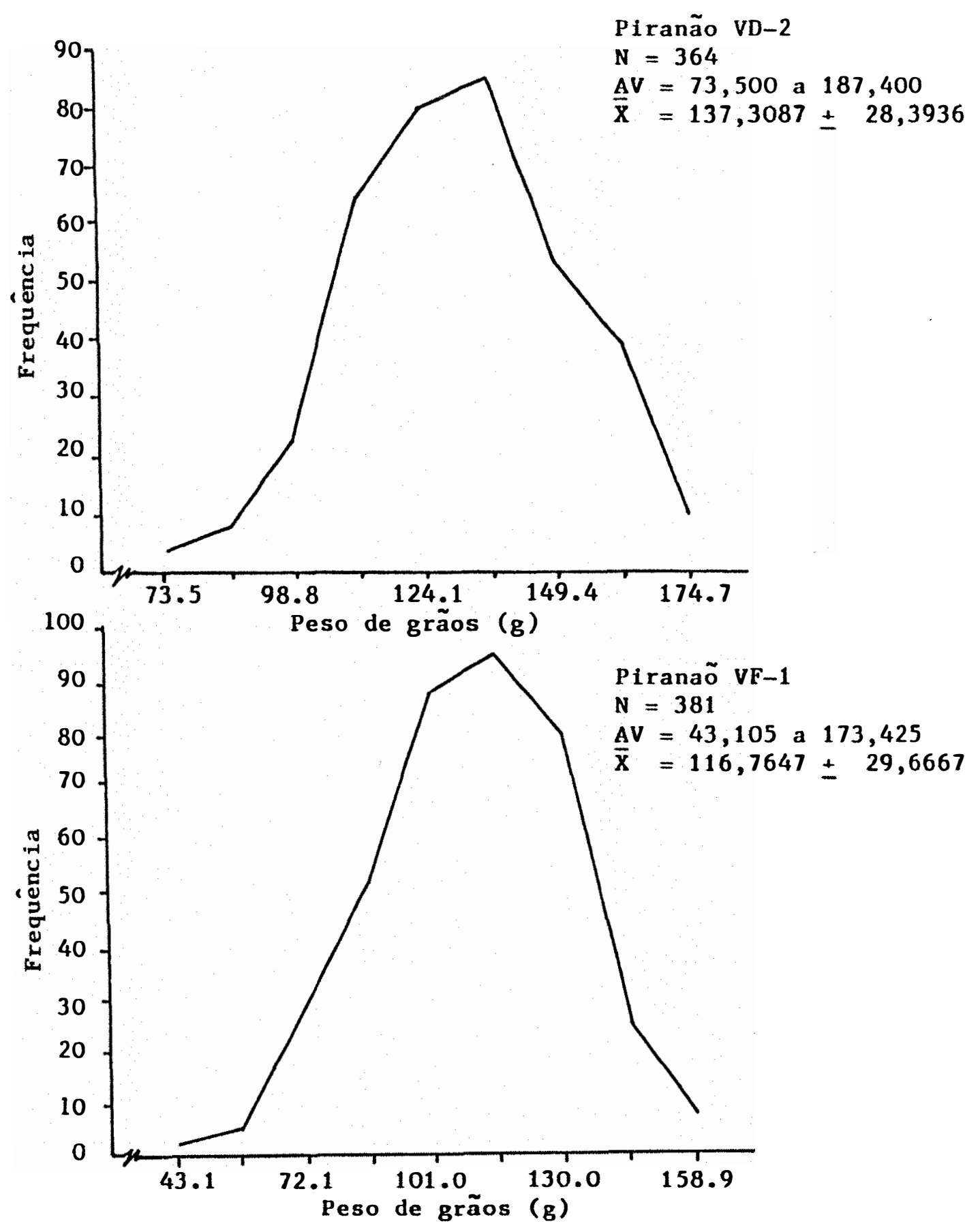

FIGURA 4 - Distribuição das médias para peso de grãos (g), re ferente à população Piranão VD-2 e Piranaõ VF-1, destacando-se o numero de médias (N), a amplitude de variancia (AV) e a média geral $(\bar{X})$ com o res pectivo intervalo de confiança (IC) a $5 \%$ de proba bill dade.PI racicaba-SP. (Caterpil lar). 1985/86. 


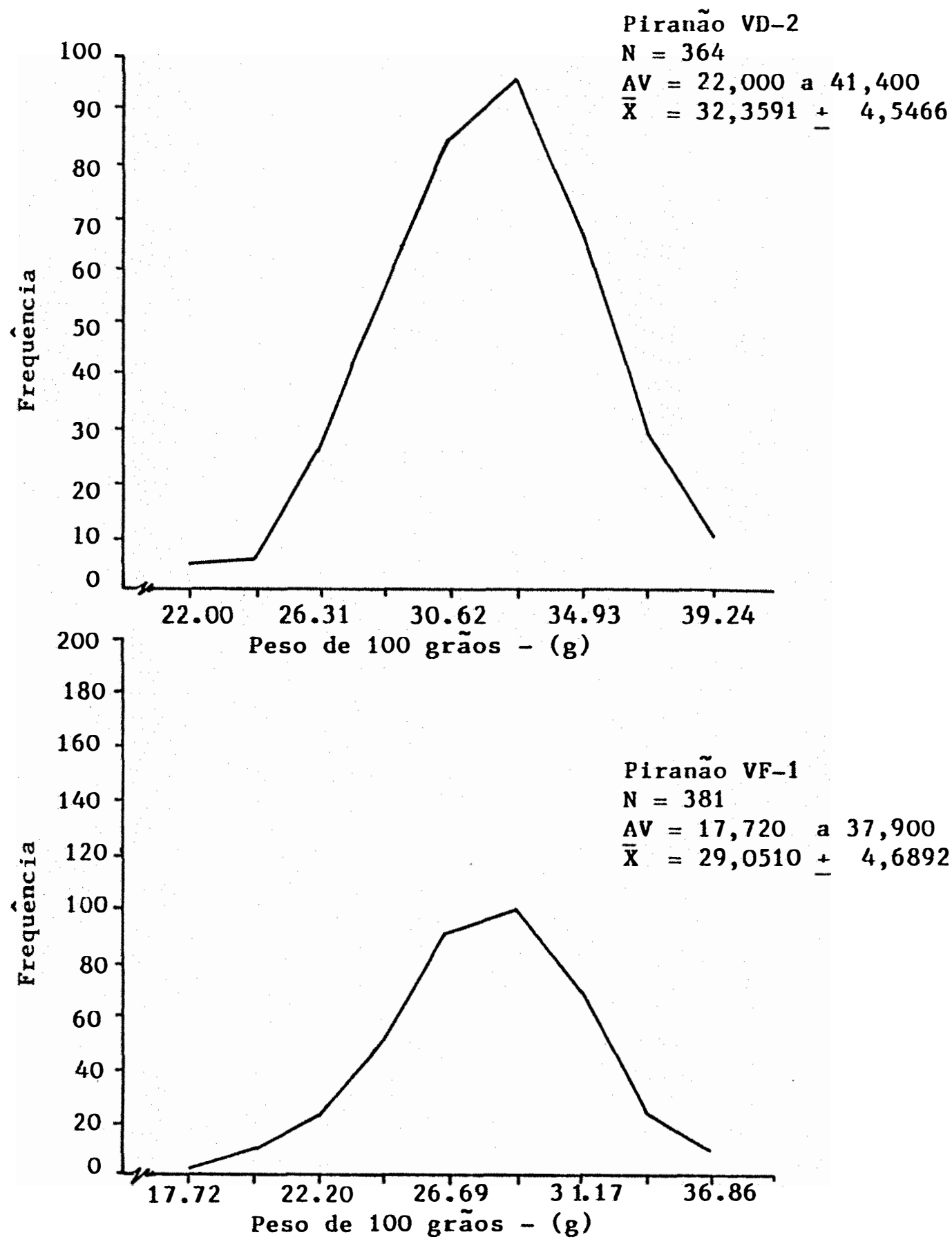

FIGURA 5 - Distribuição das médias para peso de 100 grãos (g) referente à população Piranão VD-2 e VF-1, destacan do-se o numero de médias $(N)$, a amplitude de variação (AV) e a média geral $(\bar{X})$, com o respectivo in-

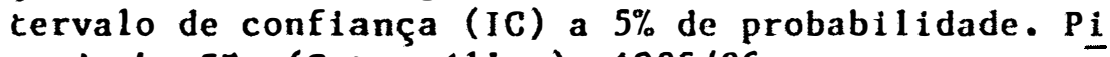
raclcaba-SP. (Caterpillar). 1985/86. 


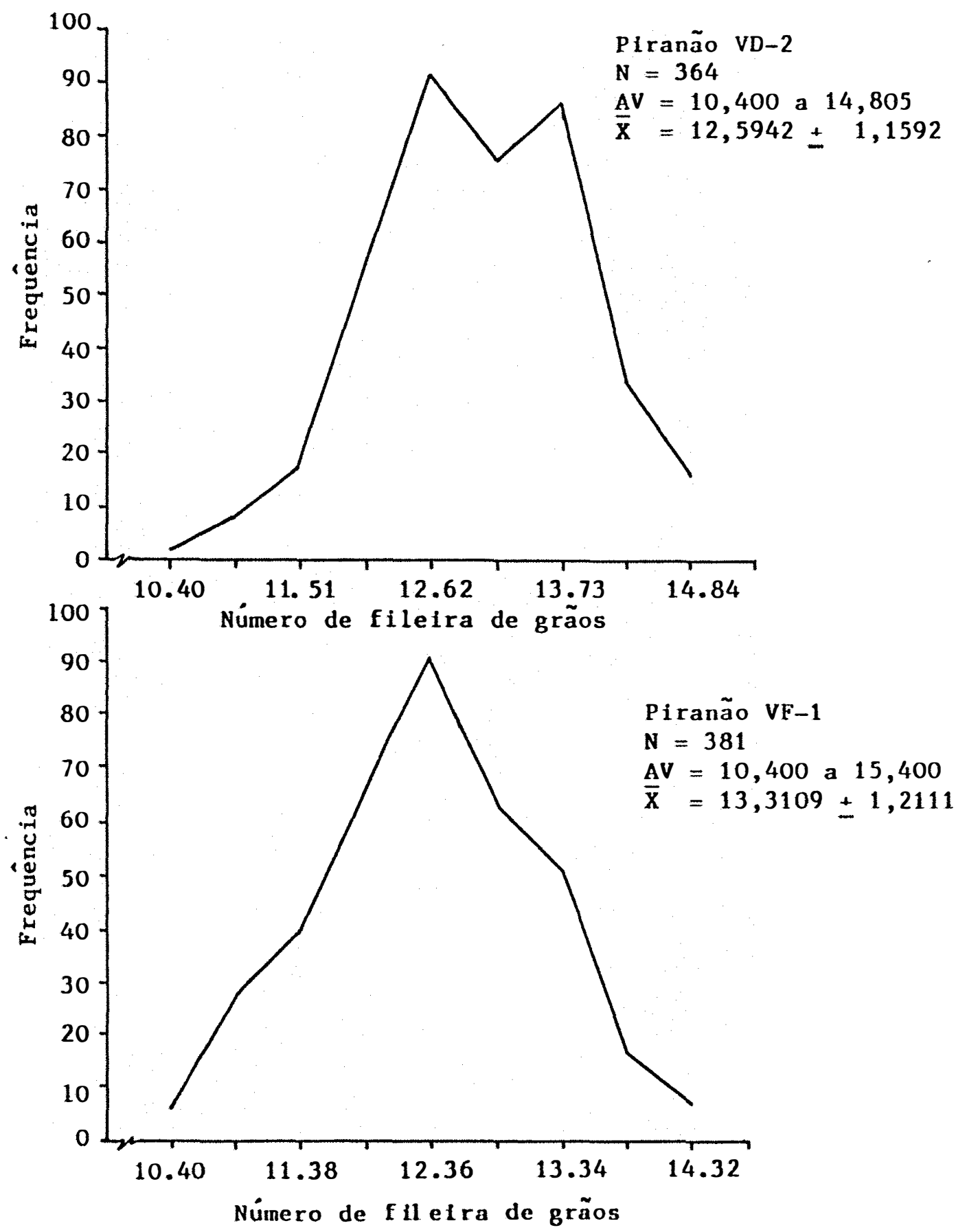

FIGURA 6 - Distribuição das médias para número de fileiras de grãos (no fileira/espiga), referente à população Piranão VD-2 e Piranão $V F-1$, destacando-se o núme ro de médias $(N)$, a amplitude de variação (AV) $\bar{e}$ a media geral $(\bar{X})$ com o respectivo intervalo de con fiança (IC) a 5\% de probabilidade.Piracicaba-SP (Caterpillar). 1985/86. 


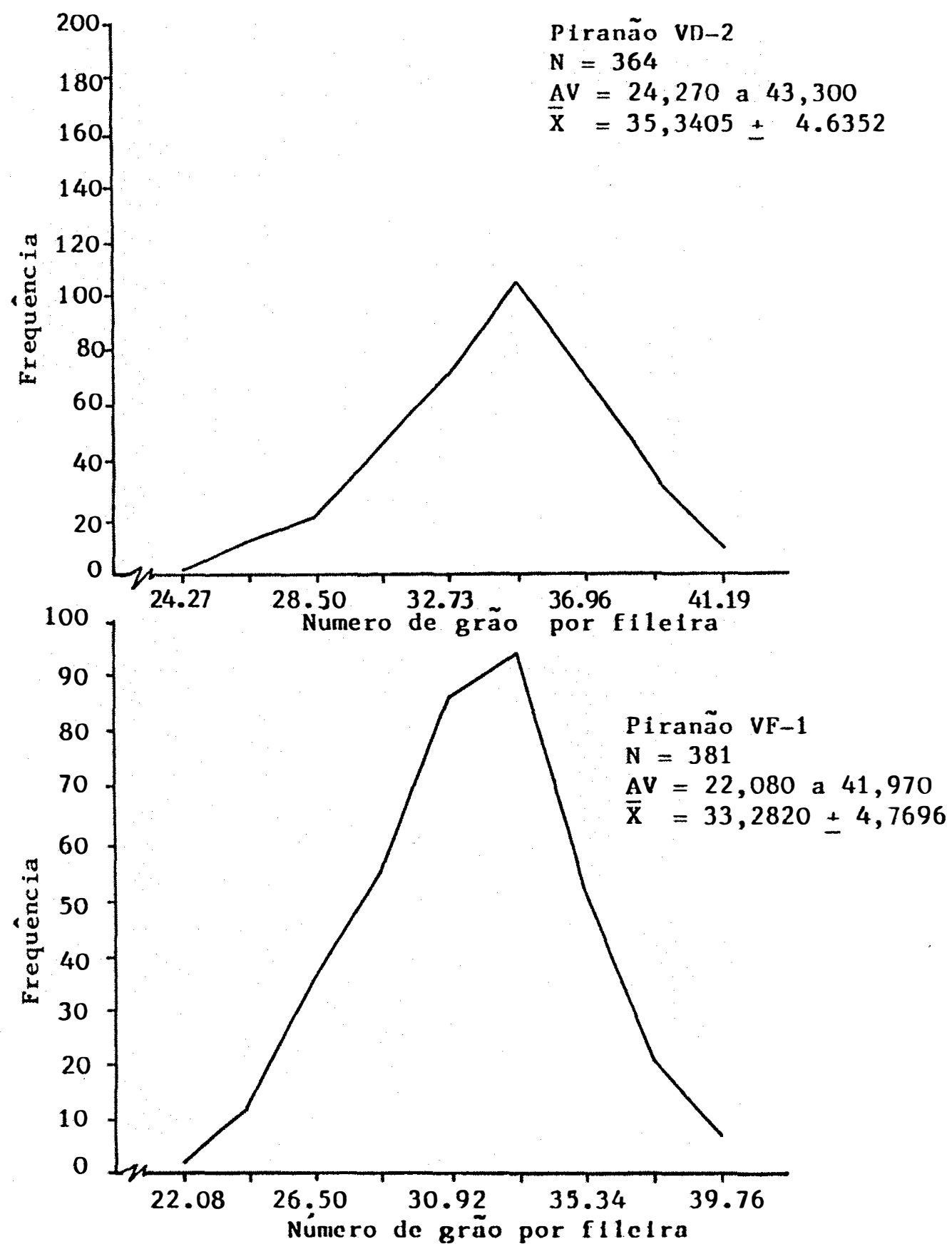

FIGURA 7 - Distribuição das médias para número de grãos por fileira (№ grãos/fileira) referente às popula ções Piranão VD-2 e Piranão VF-1, destacando -se o número de médias (N), a amplitude de variação (AV) e a média geral ( $\bar{X})$ com respectivo interva10 de confiança (IC) a $5 \%$ de probabilidade. Pira cicaba-SP. (Caterpillar). 1985/86. 


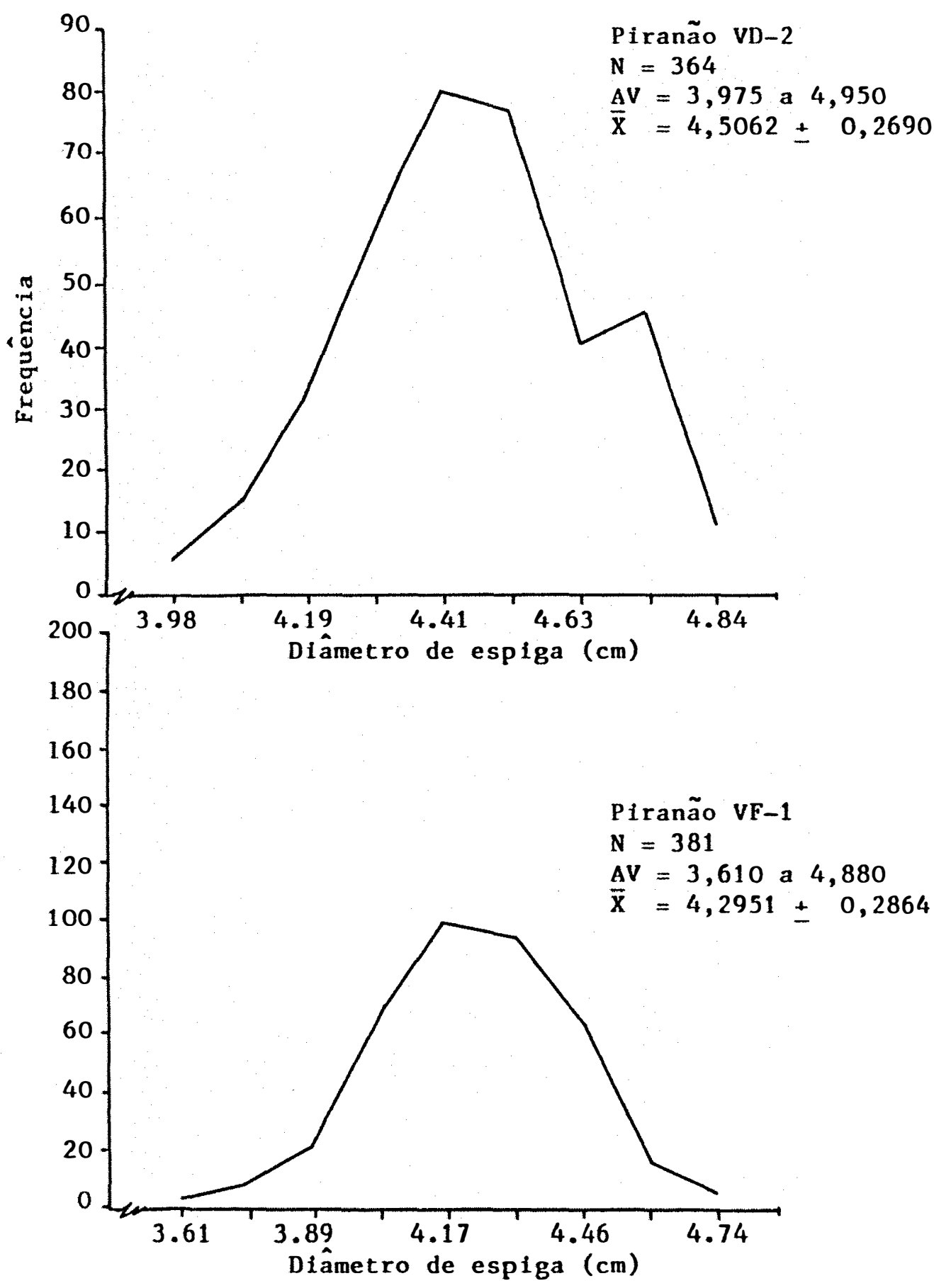

FIGURA 8 - Distribuição das médias para diâmetro de espiga (cm) referente as populações PIranão VD-2 c Piranão VF-1, destacando-se o número de médlas (N), a amplitude de variação (AV) e a média geral ( $\bar{X})$, com o respectivo intervalo de confiança (IC) a $5 \%$ de probabilidade. Piracicaba- SP. (Caterpillar). 1985/86. 


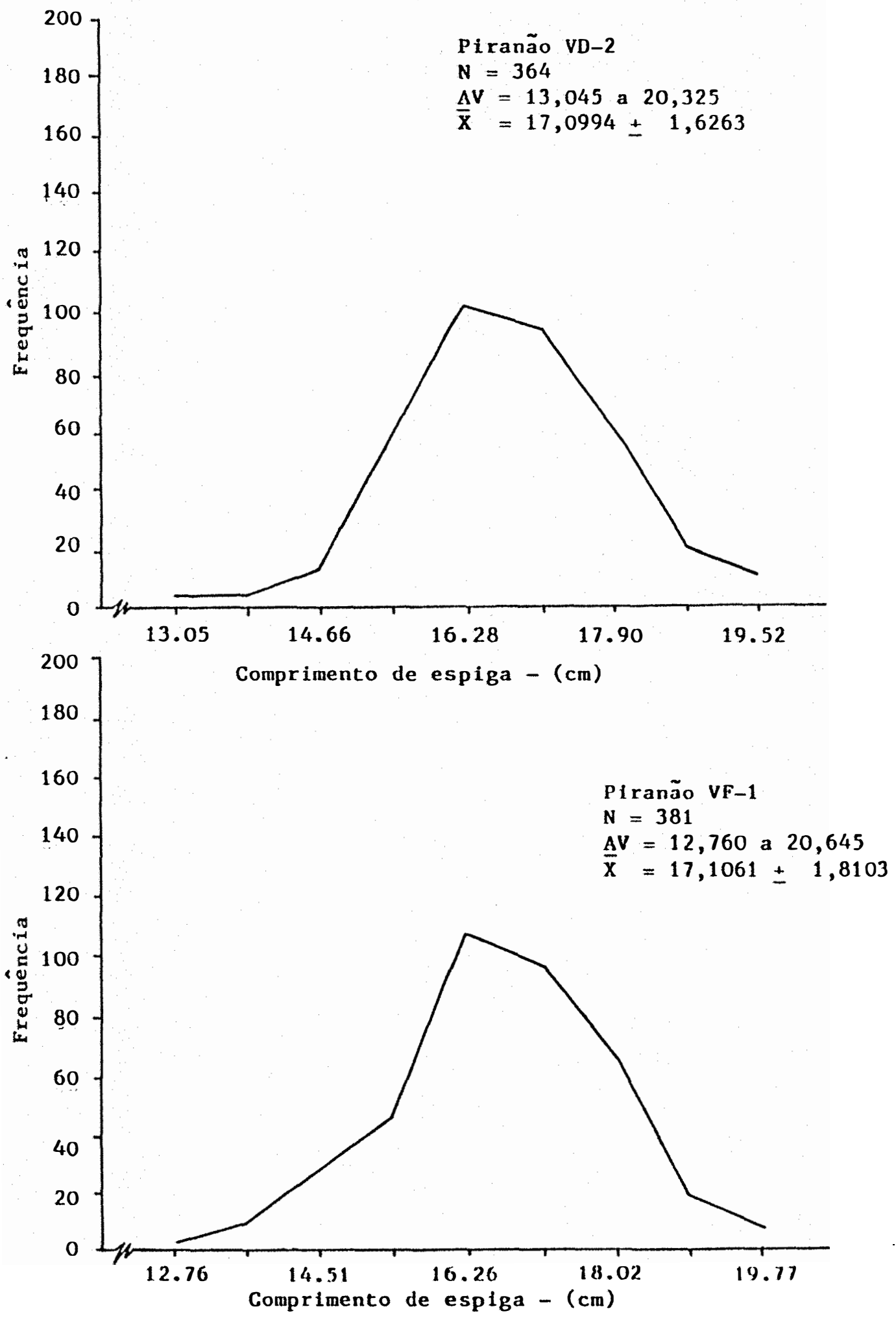

FIGURA 9 - Distribuição das médias para comprimento de espiga (cm) referente as populações Piranão VD-2 e Piranão VF-1, destacando-se o número de medias (N) a amplitude de variação (AV) e a média geral ( $\bar{X}$ ) com

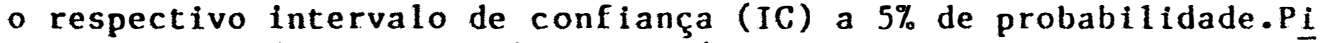
racicaba-SP. (Caterpillar). 1985/86. 


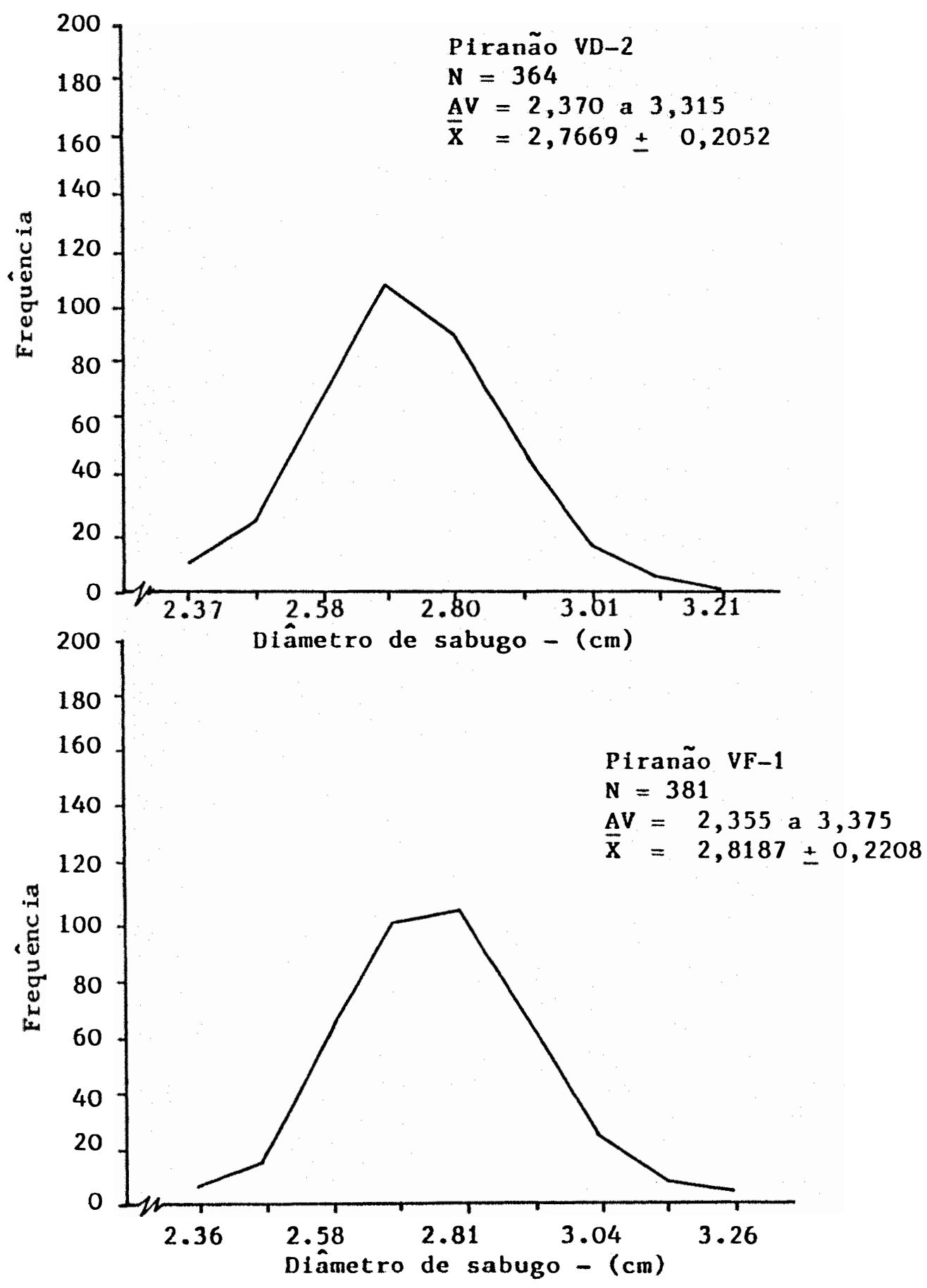

FIGURA 10 - Distribuição das médias para diâmetro de sabugo $(\mathrm{cm})$ referente as populações Piranão VD-2 e Piranão VF-1, destacando-se o numero de médias $(N)$, a amplitude de variação (AV) e a média geral $(\bar{X})$, com o respectivo intervalo de confiança (IC) a $5 \%$ de probabilidade.P racicaba-SP. (Caterpillar). 1985/86. 

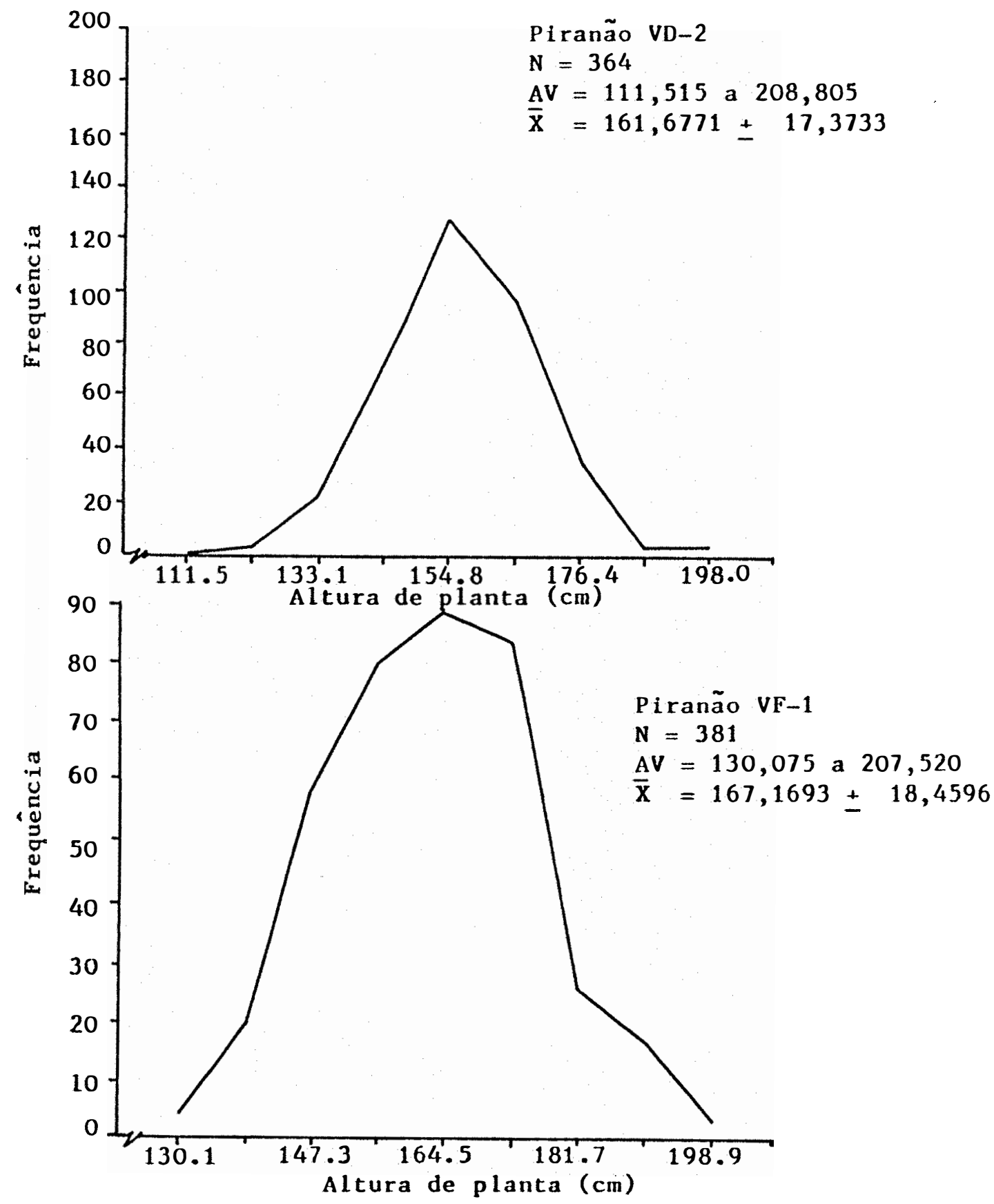

FIGURA 11 - Distribuição das médias de al tura de planta $(\mathrm{cm})$, re ferentes as populações Pirañão VD-2 e Piranão VF-1, destacando-se o numero de médias ( $N$ ), a amplitude de variação $(A V)$ e a média geral $(\bar{X})$, com o respectivo

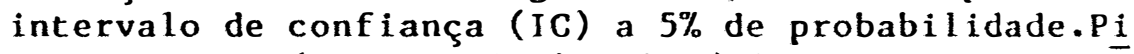
racicaba-SP. (Caterpillar). 1985/86. 


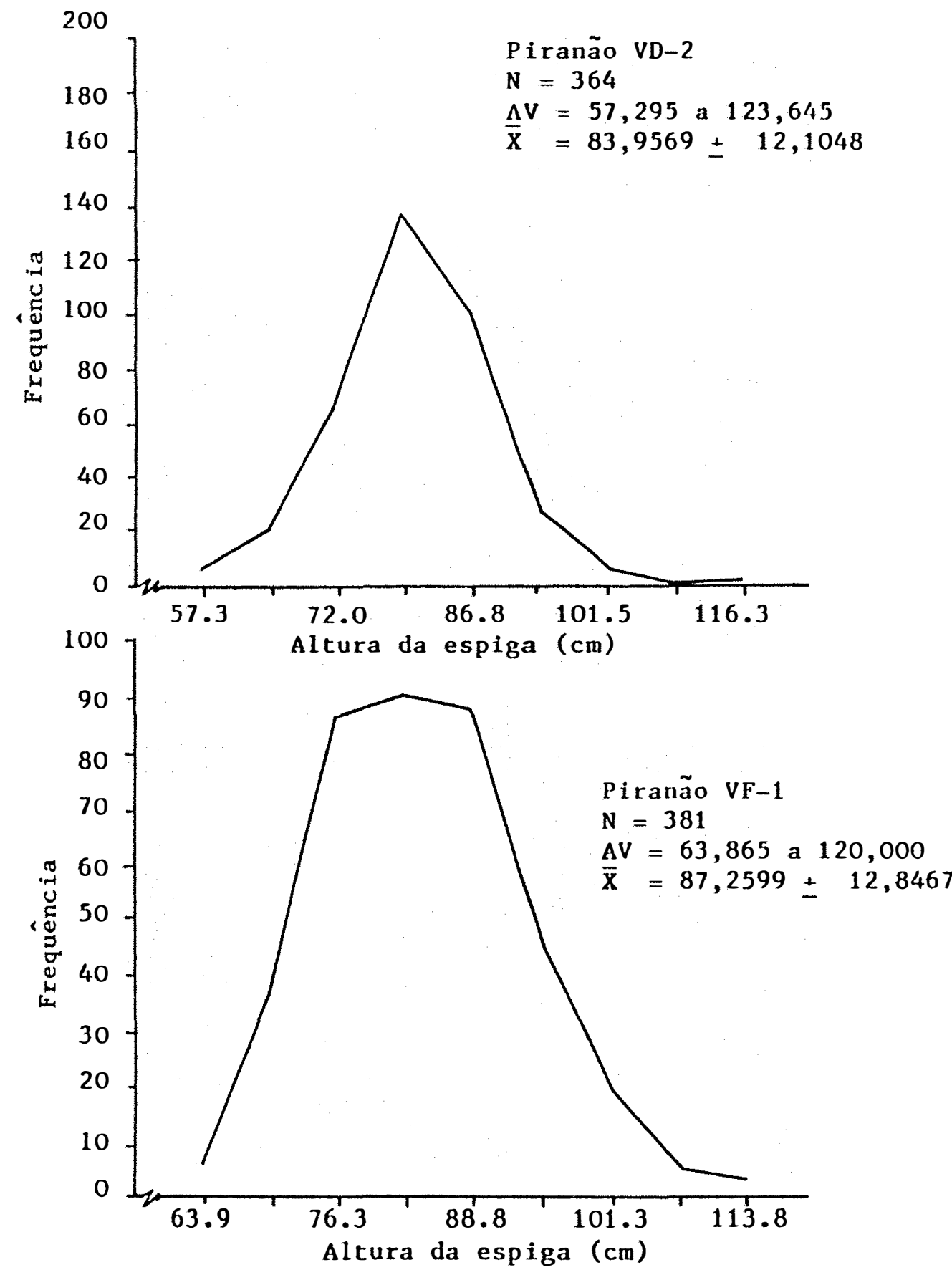

Figura 12 - Distribuição das médias de altura de cspiga (cm), re ferentes a população piranão $V D-2$ e Plranao Vli-1, destacando o numero de médias (N), a amplitude de variação (AV) e a média geral $(\bar{X})$ com respectivo in tervalo de confiança (IC) a $5 \%$ de probabilidade. PI racicaba-SP. (Caterpillar). 1985/86. 
A P $\hat{E}$ N D I C E 
Tabela 1 - Análise do gráo de milho dentado amarelo (INGLET, 1970).

\begin{tabular}{cc}
\hline Componente & Amplitude (\%) \\
\hline Amido & $64,0-79,0$ \\
Proteina & $9,3-10,7$ \\
Lipideos & $4,0-4,8$ \\
Fibras & $2,1-2,3$ \\
Cinzas & $0,9-1,5$ \\
\hline
\end{tabular}


Tahela 2 - Composiçāo química média do grāo maduro de milho e de seus componentes (EARLE et alii, 1956).

\begin{tabular}{lcrrrrr}
\hline Fração & $\begin{array}{c}\text { Grão } \\
(\%)\end{array}$ & $\begin{array}{c}\text { Amido } \\
(\%)\end{array}$ & $\begin{array}{c}\text { Proteina } \\
(\%)\end{array}$ & $\begin{array}{r}\text { Lipideos } \\
(\%)\end{array}$ & $\begin{array}{c}\text { Açúcares } \\
(\%)\end{array}$ & $\begin{array}{c}\text { Cinza } \\
(\%)\end{array}$ \\
\hline Grão inteiro & - & 71,5 & 10,3 & 4,8 & 2,0 & 1,4 \\
Endosperma & 82,3 & 86,4 & 9,4 & 0,8 & 0,6 & 0,3 \\
Embrião & 11,5 & 8,2 & 18,8 & 34,5 & 10,8 & 10,1 \\
Pericarpo & 5,3 & 7,3 & 3,7 & 1,0 & 0,3 & 0,8 \\
Ponta & 0,8 & 5,3 & 9,1 & 3,8 & 1,6 & 1,6 \\
\hline
\end{tabular}




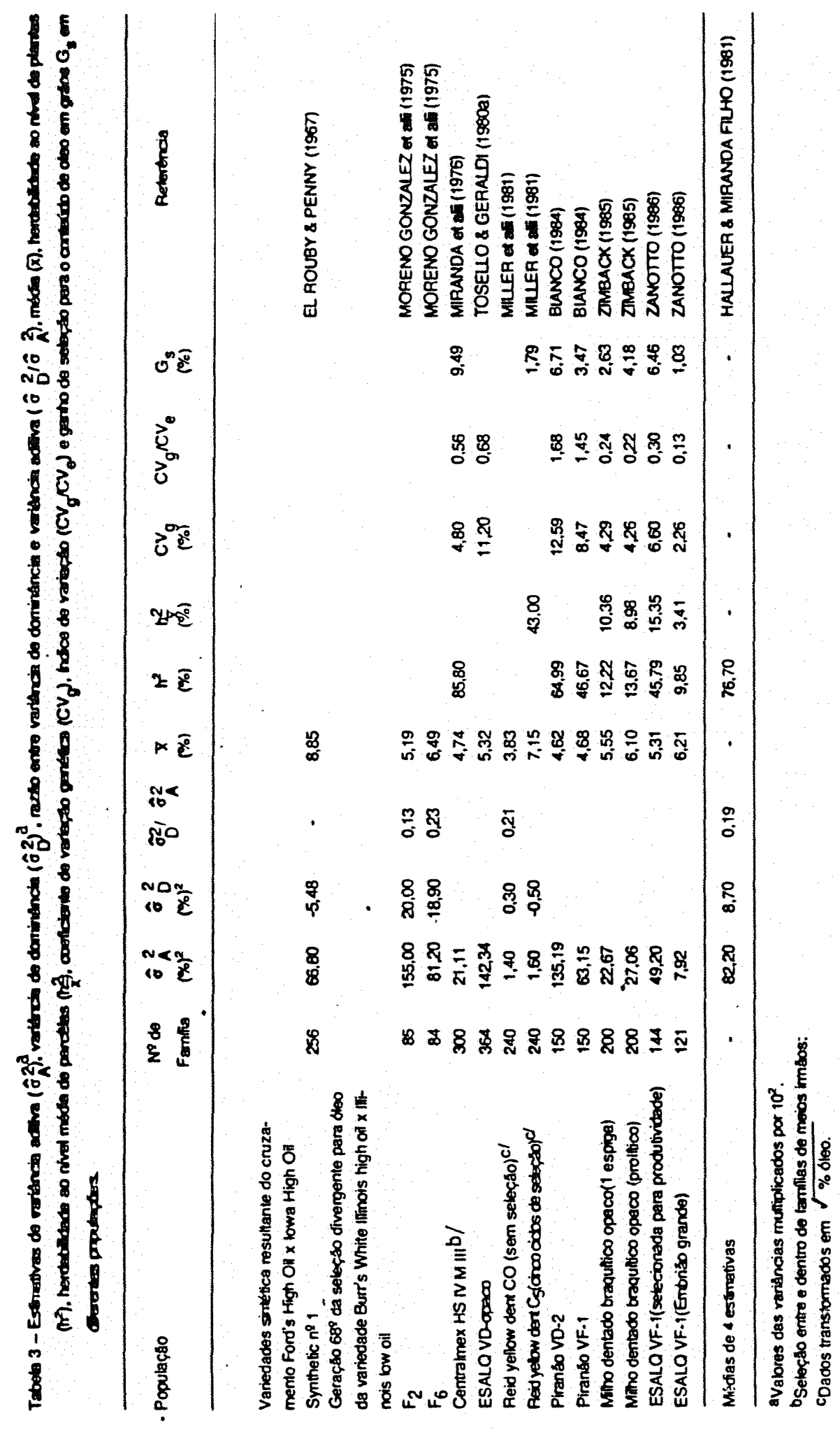




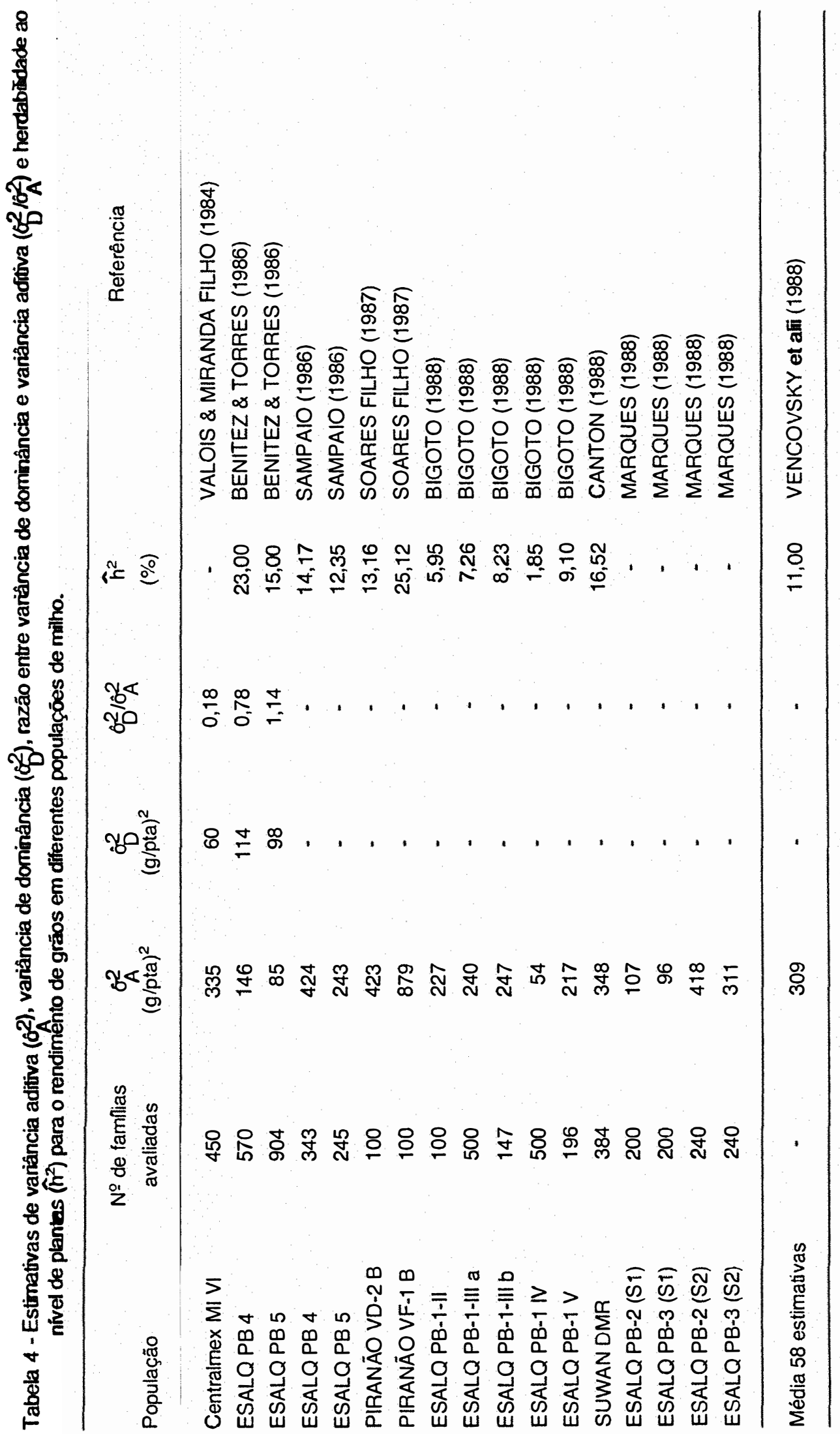




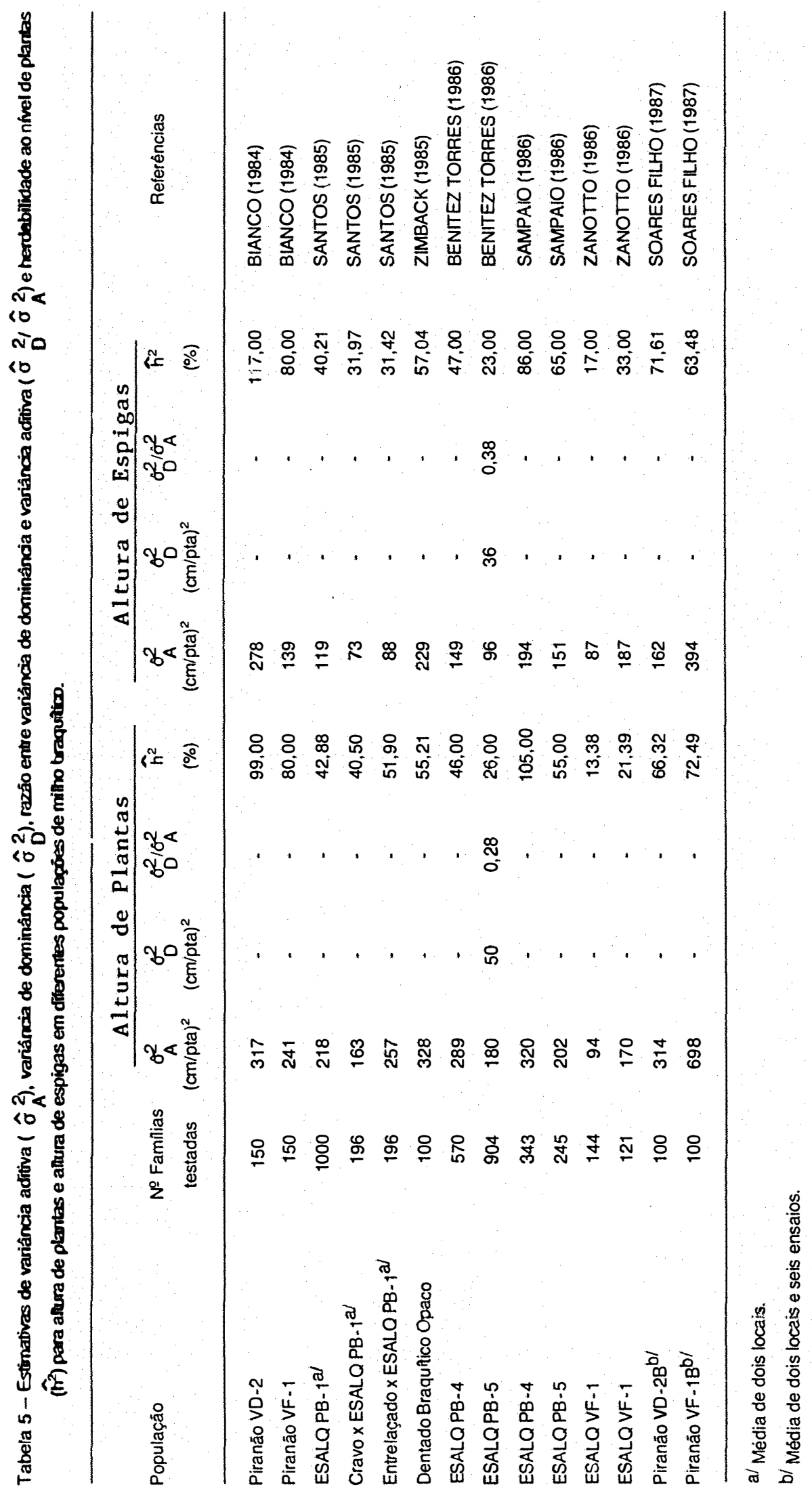




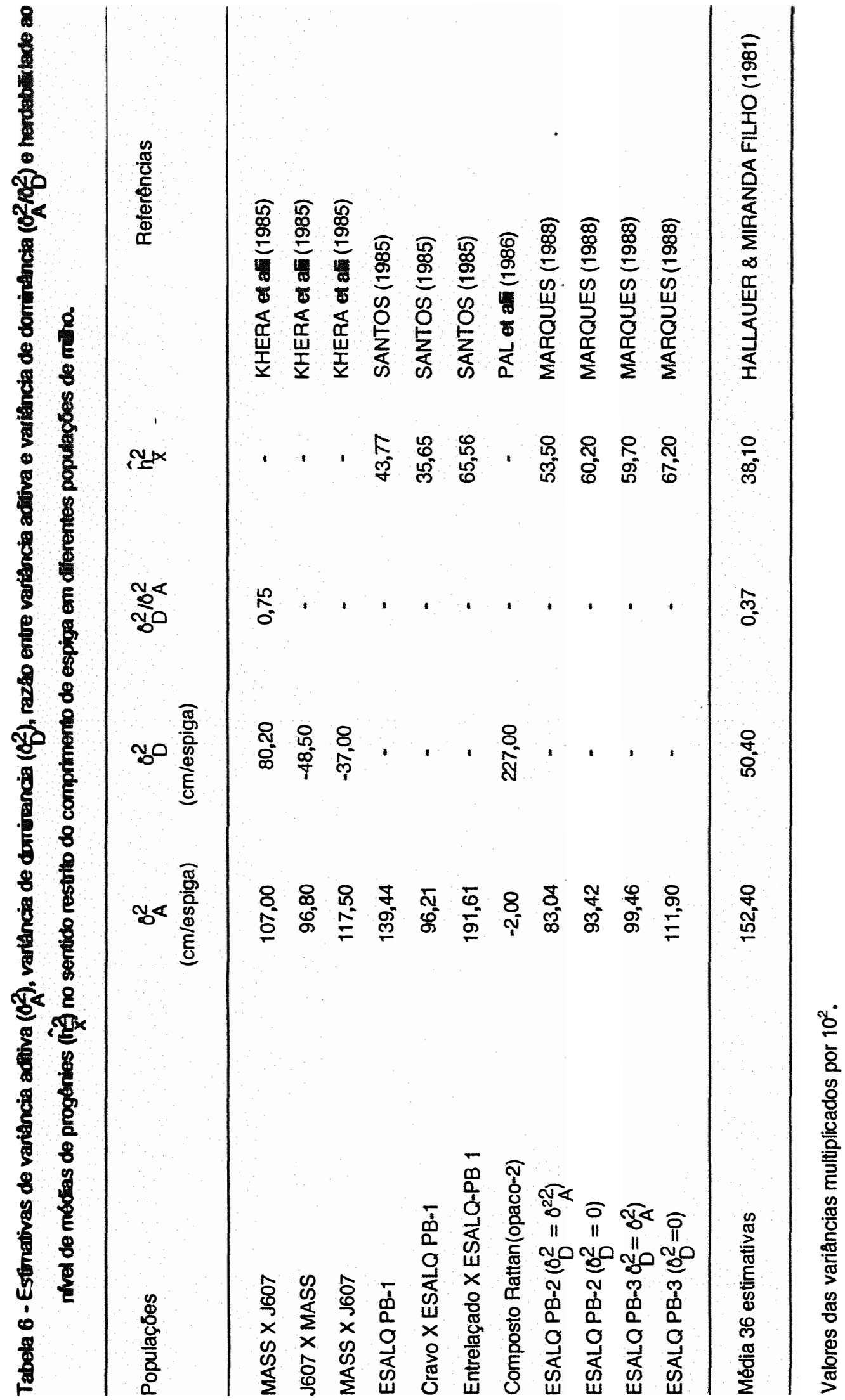




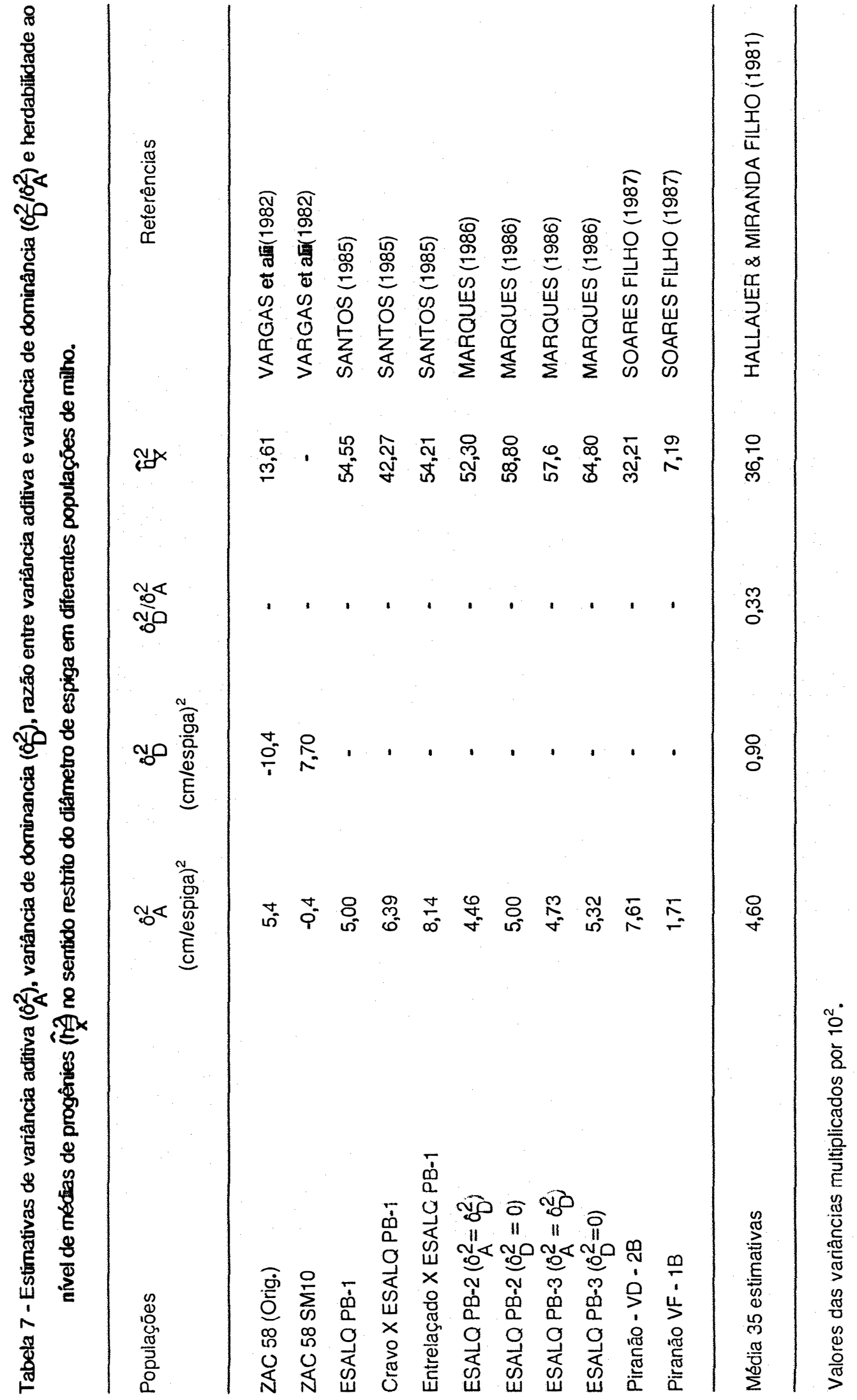




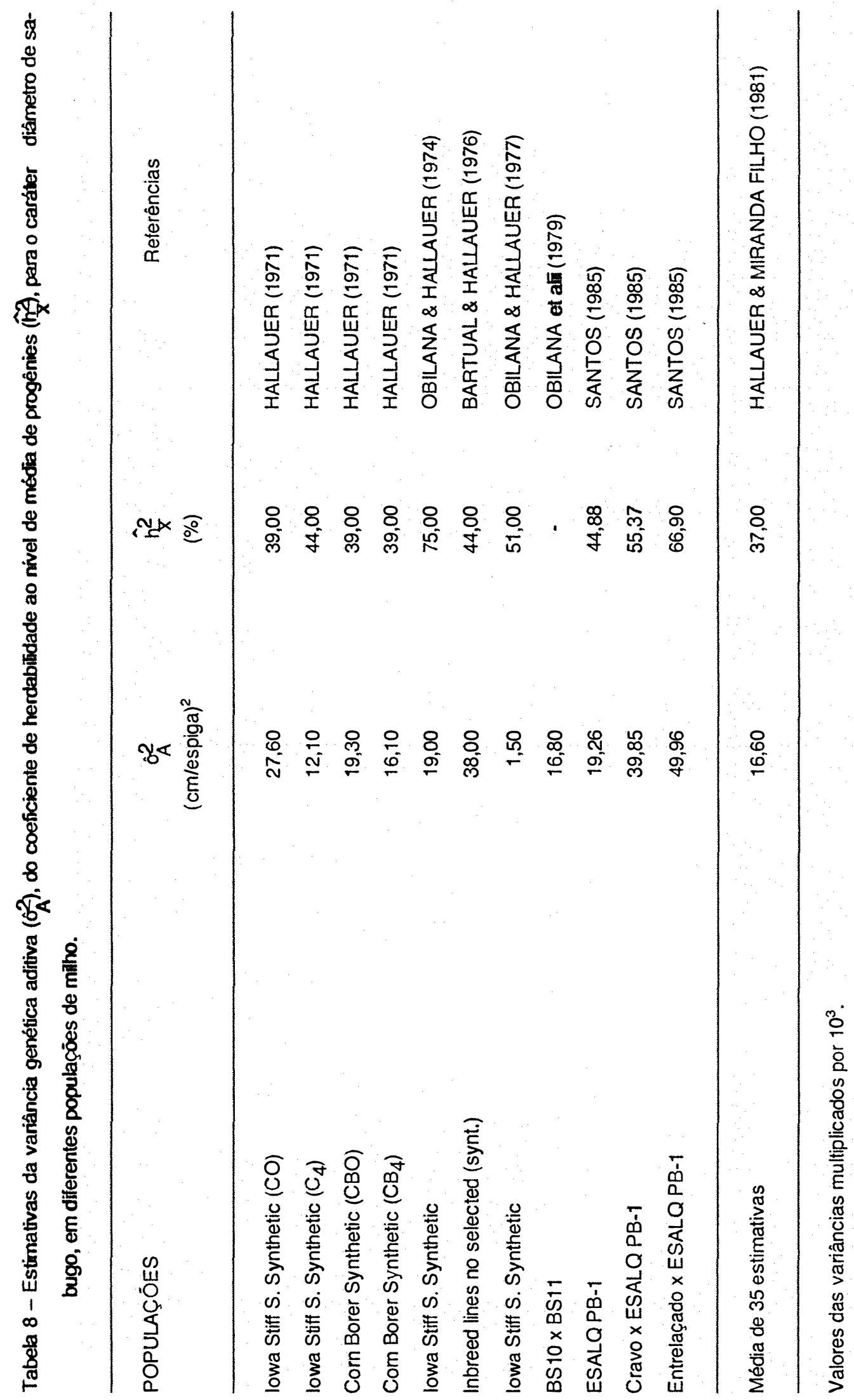




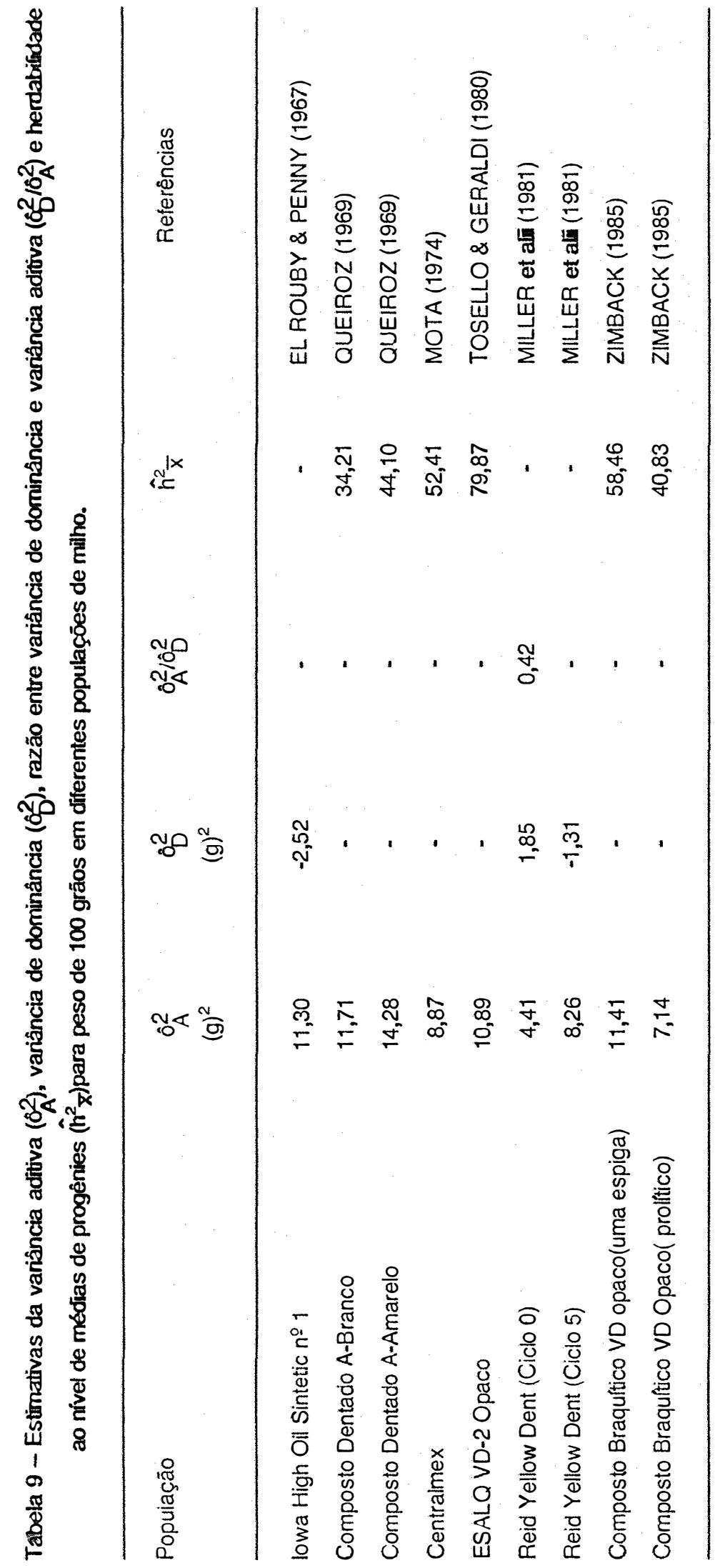




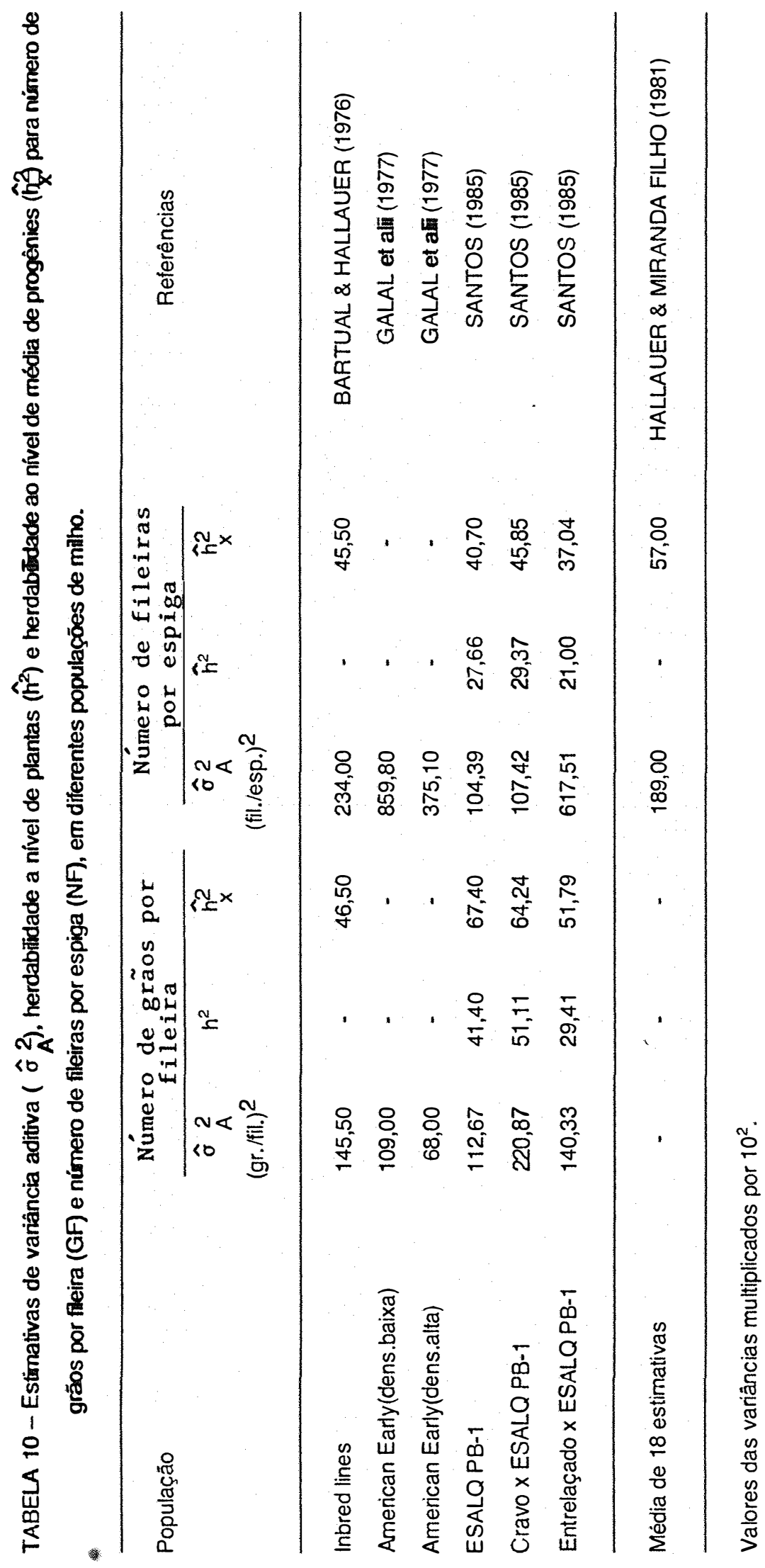


Tabela 11 - Resultados da análise qûimica do solo da área experimental. Caterpillar, Piracicaba, SP.

\begin{tabular}{ll}
\hline Parâmetros & Valores \\
\hline $\mathrm{pH} \mathrm{em} \mathrm{H} \mathrm{O}^{\mathrm{O}}$ & 4,5 \\
$\mathrm{M.O}$. & $2,3 \%$ \\
$\mathrm{P}$ & $20 \mu \mathrm{g} / \mathrm{ml}$ \\
$\mathrm{Ca}^{+}+$ & $2,68 \mathrm{meq} / 100 \mathrm{ml}$ \\
$\mathrm{Mg}^{++}$ & $0,48 \mathrm{meq} / 100 \mathrm{ml}$ \\
$\mathrm{K}^{+}$ & $0,70 \mathrm{meq} / 100 \mathrm{ml}$ \\
$\mathrm{S}$ bases & $3,86 \mathrm{meq} / 100 \mathrm{ml}$ \\
$\mathrm{CTC}$ & $8,76 \mathrm{meq} / 100 \mathrm{ml}$ \\
$\mathrm{V}$ & $44,06 \%$ \\
\hline
\end{tabular}




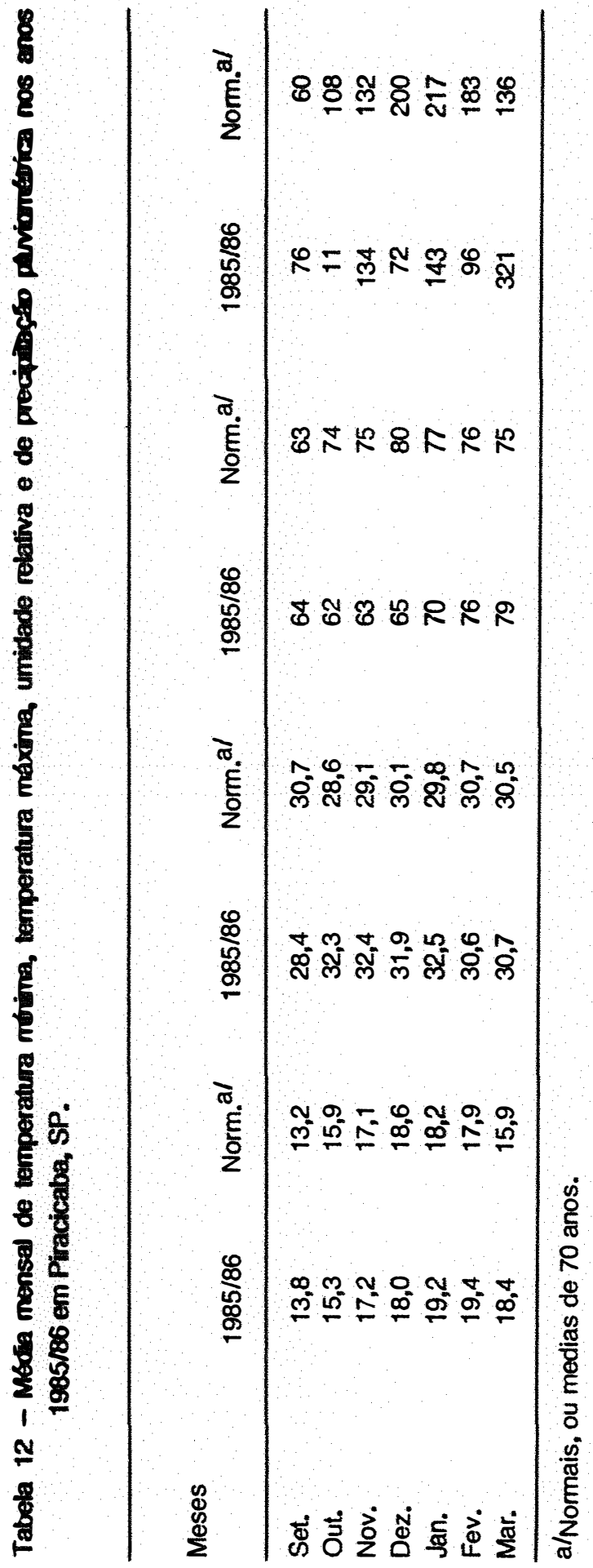


Tabela 13 - Relaçăo dos coeficientes de variação experimental (CVe\%) de caracteres de planta, observados em diversas populaçöes.

\begin{tabular}{lcccl}
\hline \multirow{2}{*}{ Caracteres } & \multicolumn{3}{c}{ Coeficiente de Variação (CVe\%) } \\
\cline { 2 - 5 } & Amplitude & Valores médios & No de estimativas & \multicolumn{1}{c}{ Fontes bibliográficasa } \\
\hline RE & $4,20-36,70$ & 15,2 & 201 & $2,6,7,8,10,11,12,15,16,17,18,19$ \\
P100 & $4,40-9,19$ & 5,97 & 4 & 5,13 \\
NF & $2,40-7,90$ & 6,60 & 6 & $1,4,5,9$ \\
GF & $8,31-17,98$ & 11,36 & 7 & $9,5,12$ \\
DE & $3,20-7,90$ & 4,90 & 21 & $2,10,12,15$ \\
CE & $5,60-11,90$ & 8,32 & 9 & $1,3,4,6,9$ \\
DS & $3,20-6,00$ & 4,60 & 18 & $10,12,15$ \\
AP & $3,60-9,20$ & 5,60 & 52 & $2,6,8,11,12,15,16$ \\
AE & $4,90-15,20$ & 8,10 & 54 & $2,6,8,10,11,12,15,16$ \\
\hline
\end{tabular}

a 1: MARQUES-SANCHEZ \& HALLAUER, 1970; 2: EL-LAKANY \& RUSSELL, 1971; 3: HALLAUER, 1971; 4: MIRANDA Fo et alii, 1972; 5: MOTA, 1974; 6: OBILANA \& HALLAUER, 1974; 7: NASPOLINI F", 1975; 8: VALVA, 1976; 9: GALAL et alii, 1977; 10: OBILANA et alii, 1979: 11: PATERNIANI et alii, 1982; 12: SANTOS, 1985; 13: ZIMBACK, 1985; 14: MARTINS, 1986: 15: SAMPAIO, 1986; 16: SOARES Fo, 1987; 17: BIGOTO, 1988; 18: CANTON, 1988; 19: MARQUES, 1988; 20: VENCOVSKY ol alii, 1983. 